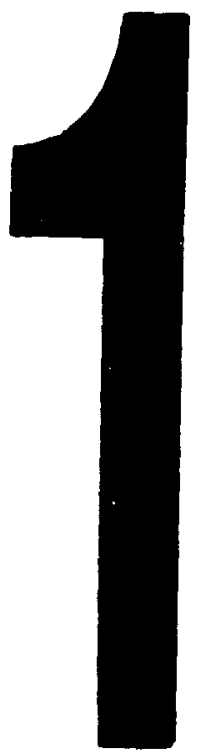

PM-1 3Y" $x 4 "$ PHOTOGRAPHIC MICROCOPY TARCET MaS 1010 AMSH/LO "Z EOUNALENT

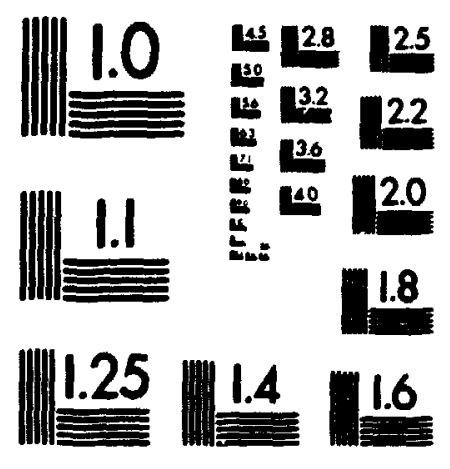




\section{LIST OF TABLES}

Table 1:

CFFS Halifax and Esquimalt Population Distribution, by rank ....... 54

Table 2A:

Distribution of Respondents, by Rank CFFS Halifax .......... 56

Table 2B:

Distribution of Respondents, by Rank (\% of total population)

CFFS Halifax ............................ 57

Table 3A:

Distribution of Respondents, by Rank CFFS Esquimalt $\ldots \ldots \ldots \ldots \ldots 58$

Table 3B:

Distribution of Respondents, by Rank (\% of total population)

CFFS Esquimalt $\ldots \ldots \ldots \ldots \ldots \ldots \ldots \ldots \ldots \ldots \ldots \ldots \ldots \ldots$

Table 4:

Categories of Independent Variables $\ldots \ldots \ldots \ldots \ldots \ldots \ldots \ldots \ldots 68$

Table 5:

Variables in the Turnover Intentions Model $\ldots \ldots \ldots \ldots \ldots \ldots \ldots 69$

Table 6:

Correlations between Independent and Dependent Variabies ........ 70

Table 7:

Correlations between Intervening and Dependent Variables ........ 70

Table 8:

Cross tabulation, Intentions to Leave by Rank Category $\ldots \ldots \ldots \ldots \ldots$

Table 9:

Cross tabulation, Intentions to Leave by Service Category ......... 106

Table 10:

Cross tabulation, Intentions to Leave by Geographical Location . . . . . . 107

Table 11:

Cross tabulation, Intentions to Leave by Perceived Alternatives . . . . . 108 


\title{
ORGANISATIONAL COMMITMENT, JOB SATISFACTION AND INTENTIONS TO LEAVE: A SAMPLE SURVEY OF THE CANADIAN ARMED FORCES (NAVY)
}

\author{
by
}

\section{LESLEY J. OAKES}

\author{
A thesis submitted to \\ the Faculty of Graduat: Studies and Research \\ in partial t:lfillment of \\ the requirements for the degree of
}

Master of Arts

Department of Sociology and Anthropology

Carleton University

Ottawa, Ontario

1 August 1991

(C) copyright

1991, Lesley J. Oakes 
National Library of Canada

Canadian Iheses Service

Bibliothèque nationale du Canada

Service des thèses canadiennes

Ottawa, Canada

KIA ONA

The author has granted an irrevocable nonexclusive licence allowing the National Library of Canada to reproduce, barl, distribute or sell copies of his/her thesis by any means and in any form or format, making this thesis available to interested persons.

The author retains ownership of the copyright in his/her thesis. Neither the thesis nor substantial extracts from it may be printed or otherwise reproduced without his/her permission.
L'auteur a accordé une licence irrévocable et non exclusive permettant à la Bibliothéque nationale du Canada de reproduire, preter. distribuer ou vendre des copies de sa thése de quelque manière et sous quelque forme que ce soit pour mettre des exemplaires de cette thèse à la disposition des personnes intéressées.

L'auteur conserve la proprièté du droit d'auteur ciui protège sa thèse. Ni la thèse ni des extraits substantiels de celle-ci ne doivent etre imprimés ou autrement reproduits sans son altiorisation. 


\begin{abstract}
This study examines three correlates of organisational commitment and job satisfaction: rank (status), service (tenure), and environmental pull (perceived alternatives) within the context of a model of turnover intentions. A sample (224) of Canadian Forces Naval personnel from Canadian Forces Fleet Schools at Halifax and Esquimalt were surveyed. Measures of organisational commitment and job satisfaction were found to be negatively related to leave intentions. Those personnel with higher rank and longer service indicated that they were more likely to have intentions to leave than those with less rank and less service. Impiications of the findings for military policy are discussed.
\end{abstract}


The undersigned recommend to the Facuity of G:aduate studies and Research acceptance of the thesis

ORGANISATIONA: COMMITMENT, JOB SATISFACTION

AND INTENTIONS TO LEAVE: A SAMPLE SURVEY OF THE CANADIAN ARMED FORCES (NAVY)

submitted by Lesley J. Oakes, B.A., M.B.A.

in partial fulfilment of the requirements for

the degree of Master of Arts

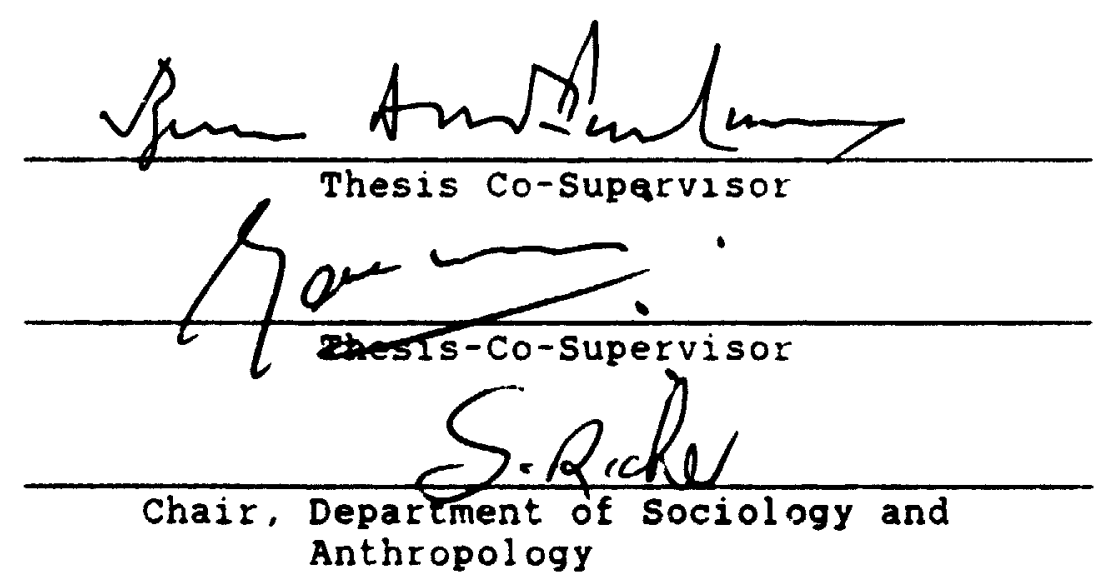

Carieton University

August 1, 1991 


\section{ACKNOWLEDGEMENTS}

The author wishes to acknowledge the invaluable advice, support and guidance in the conduct of this study provided by the members of my advisory committee, Professors Bruce McFarlane and John De Vries. My appreciation also goes to Major C.D. Lamerson whose professional assistance was instrumental in getting this project off the ground. Lastly, I wish to thank, Captain L.P. Oakes, whose patience, understanding and encouragement, particularly throughout the past two years, has seen me over the periods of frustration and doubts.

I wish to dedicate this work to my father, who, in life and in death, gave me the inspiration to begin, the courage to continue and the strength to finish. 


\section{TABLE OF CONTENTS}

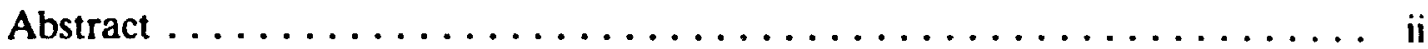

Acknowledgements $\ldots \ldots \ldots \ldots \ldots \ldots \ldots \ldots \ldots \ldots \ldots \ldots \ldots$ iii

Table of Contents $\ldots \ldots \ldots \ldots \ldots \ldots \ldots \ldots \ldots \ldots \ldots \ldots \ldots \ldots \ldots$ iv

List of Tables $\ldots \ldots \ldots \ldots \ldots \ldots \ldots \ldots \ldots \ldots \ldots \ldots \ldots \ldots \ldots \ldots \ldots \ldots$

List of Figures $\ldots \ldots \ldots \ldots \ldots \ldots \ldots \ldots \ldots \ldots \ldots \ldots \ldots \ldots \ldots \ldots \ldots \ldots \ldots$

Chapter 1 - Introduction $\ldots \ldots \ldots \ldots \ldots \ldots \ldots \ldots \ldots \ldots \ldots \ldots \ldots$

Chapter 2 - A Review of the Literatures $\ldots \ldots \ldots \ldots \ldots \ldots \ldots \ldots$. 8

Section 1 - Theoretical and Conceptual Framework ............ 8

2.1 - Organisational Commitment $\ldots \ldots \ldots \ldots \ldots \ldots \ldots \ldots \ldots, 8$

2.2 - Job Satisfaction ....................... 20

2.3 - Job Satisfaction and Organisational Commitment ......... 25

2.4 - Intentions Versus Turnover Behaviour ............... 29

Section 2 - Conceptual Framework and Causal Linkages ........... 31

2.5 - The Theoretical Model ..................... 31

2.6 - Rank (Status) and Organisational Commitment ........... 32

2.7 - Rank (Status) and Job Satisfaction ............... 35

2.8 - Length of Service (Tenure) and Organisational Commitment .... 36

2.9 - Length of Service (Tenure) and Job Satisfaction ......... 37

2.10 - Environmental Pull, Organisational Commitment, Job Satisfaction

and Turnover Intentions . . . . . . . . . . . . . . 40

2.11 - Organisational Size, Organisational Commitment, Job Satisfaction and Turnover Intentions . . . . . . . . . 42

2.12 - Organisational Commitment, Job Satisfaction and the Intentions to

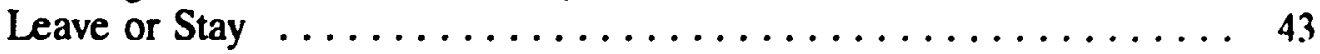

Section 3 - Conceptual Paradigm .................... 44

Section 4 - Propositions ........................ 49

Appendix 1 - Summary of Research Findings $\ldots \ldots \ldots \ldots \ldots \ldots \ldots 51$

Chapter 3 - Methodology ....................... 52

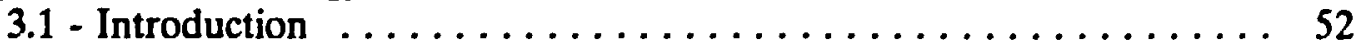

3.2 - Description of the Population $\ldots \ldots \ldots \ldots \ldots \ldots \ldots \ldots \ldots, 53$

3.3 - Survey Sample ......................... 54

3.4 - Survey Questionnaire ..................... 60

3.5 - Variables ........................... 61

3.6 - Data Analysis .......................... 65

3.7 - Demographic Description of the Sample ............ 67 
Chapter 4 - Analysis ......................... 69

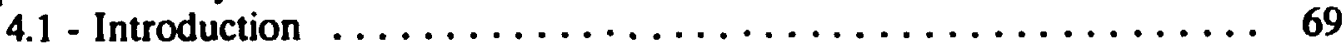

4.2 - Descriptive Analysis . . . . . . . . . . . . . . . . 71

4.3 - Inferential Analysis . . . . . . . . . . . 76

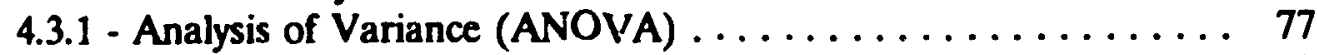

4.3.2 - Aptitude by Treatment Interactions $\ldots \ldots \ldots \ldots \ldots \ldots \ldots, 88$

4.3.3 - Regression Analysis . . . . . . . . . . . . . . . 89

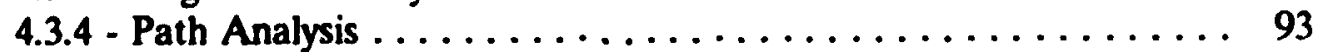

4.4 - Institutional Versus Occupational . . . . . . . . . . . . 98

4.5 - Job Satisfaction and Organisational Commitment Matrix ...... 100

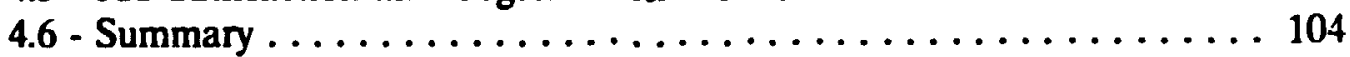

Appendix 2 - Cross Tabulation Tables ................... 105

Appendix 3 - Graphica' Representations ................. 109

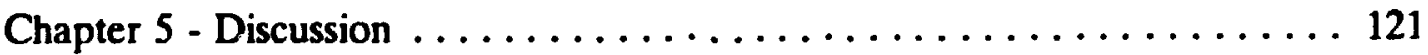

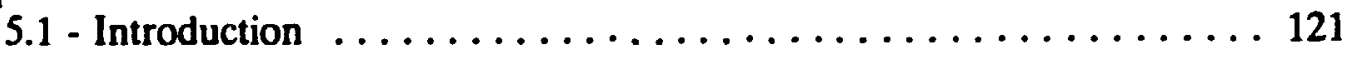

5.2 - Organisational Size ...................... 122

5.3 - Environmental Pull (Perceived Alternatives) ............ 123

5.4 - Rank .............................. 125

5.5 - Service ............................. 130

5.6 - Job Satisfaction ........................ 134

5.7 - Organisational Commitment $\ldots \ldots \ldots \ldots \ldots \ldots \ldots \ldots \ldots \ldots$

5.7.1 - Institutional and Occupational Commitment ......... 137

5.8 - The Model of Turnover Intentions . . . . . . . . . . . . 138

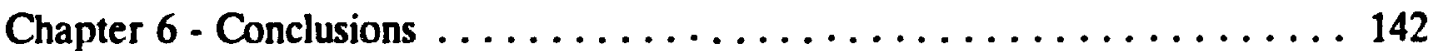

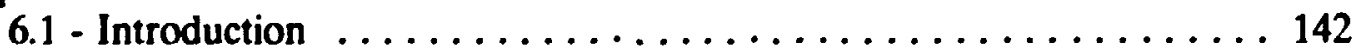

6.2 - Research concerns . . . . . . . . . . . . . . . . 142

6.3 - Implications for future research $\ldots \ldots \ldots \ldots \ldots \ldots \ldots \ldots \ldots \ldots$

6.4 - Poli.y implications . . . . . . . . . . . . . . . . 151

6.5 - Conclusion ............................ 153

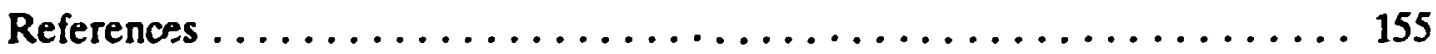

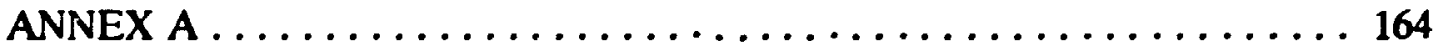




\section{LIST OF TABLES}

Table 1:

CFFS Halifax and Esquimalt Population Distribution, by rank ....... 54

Table 2A:

Distribution of Respondents, by Rank CFFS Halifax ........... 56

Table 2B:

Distribution of Respondents, by Rank (\% of total population)

CFFS Halifax ............................. 57

Table 3A:

Distribution of Respondents, by Rank CFFS Esquimalt $\ldots \ldots \ldots \ldots \ldots 58$

Table 3B:

Distribution of Respondents, by Rank (\% of total population)

CFFS Esquimalt . .............................. 59

Table 4:

Categories of Independent Variables $\ldots \ldots \ldots \ldots \ldots \ldots \ldots \ldots \ldots 68$

Table 5:

Variables in the Turnover Intentions Model $\ldots \ldots \ldots \ldots \ldots \ldots \ldots 69$

Table 6:

Correlations between Independent and Dependent Variabies ........ 70

Table 7:

Correlations between Intervening and Dependent Variables ........ 70

Table 8:

Cross tabulation, Intentions to Leave by Rank Category $\ldots \ldots \ldots \ldots \ldots$

Table 9:

Cross tabulation, Intentions to Leave by Service Category $\ldots \ldots \ldots \ldots 106$

Table 10:

Cross tabulation, Intentions to Leave by Geographical Location . . . . . . 107

Table 11:

Cross tabulation, Intentions to Leave by Perceived Alternatives $\ldots \ldots \ldots 108$ 
Table 12:

Regression Values for Predictor Variables on Criterion Measure . . . . . . 89

Table 13:

Regression Values for Significant Intervening Variables or Criterion . . . . 92

Table 14:

Regression Values for Significant Independent and Intervening

Variables on Criterion Measure ..................... 93

Table 15:

Military Ethos Scale by Rank Category . . . . . . . . . . . . . . . . . . 99

Table 16:

Descriptive Statistics for MES . . . . . . . . . . . . . . . 100

Table 17:

Matrix of Job Satisfaction and Organisational Commitment (cell \%) . . . 101

Table 18:

Matrix of Job Satisfaction and Organisationa! Commitment (cell \%)

Intentions to Leave $=$ Likely $\ldots \ldots \ldots \ldots \ldots \ldots \ldots \ldots \ldots \ldots \ldots \ldots$

Table 19:

Matrix of Job Satisfaction and Organisational Commitment (cell \%)

Intentions to Leave $=$ Undecided

Table 20:

Matrix of Job Satisfaction and Organisational Commitment

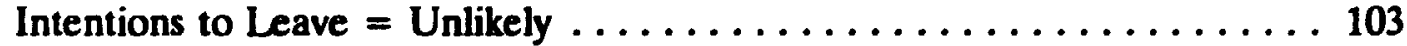

Table 21:

Voluntary Releases for the Navy 1989 and $1990 \ldots \ldots$. . . . . . . . . 127

Table 22:

Officer Promotions for Naval Occupations for the Years 1988 to 1990 . . . 129

Table 23:

Survey Sample Median JDI Scores and Normative Scores at

50th Percentile 


\section{LIST OF FIGURES}

Figure 1:

Model of Turnover Intentions $\ldots \ldots \ldots \ldots \ldots \ldots \ldots \ldots \ldots \ldots \ldots, \ldots \ldots$

Figure 2:

Model of Turnover Intentions for the Strdy $\ldots \ldots \ldots \ldots \ldots \ldots \ldots \ldots, \ldots \ldots$

Figure 3:

Intentions to Leave by $\operatorname{Rank} \ldots \ldots \ldots \ldots \ldots \ldots \ldots \ldots \ldots \ldots$

Figure 4:

Organisational Commitment (OCQ) by Rank $\ldots \ldots \ldots \ldots \ldots \ldots \ldots 110$

Figure 5:

Military Ethos Scale (MES) by Rank $\ldots \ldots \ldots \ldots \ldots \ldots \ldots \ldots \ldots \ldots$

Figure 6:

Job Satisfaction with Promotion by Rank $\ldots \ldots \ldots \ldots \ldots \ldots \ldots \ldots$

Figure 7:

Intentions to Leave by Service $\ldots \ldots \ldots \ldots \ldots \ldots \ldots \ldots \ldots \ldots \ldots$

Figure 8:

Organisational Commitment (OCQ) by Service $\ldots \ldots \ldots \ldots \ldots \ldots \ldots 114$

Figure 9:

Military Ethos Scale (MES) by Service $\ldots \ldots \ldots \ldots \ldots \ldots \ldots \ldots \ldots$

Figure 10:

Job Satisfaction with Promotion by Service $\ldots \ldots \ldots \ldots \ldots \ldots \ldots \ldots$

Figure 11:

Intentions to Leave by Perceived Alternatives $\ldots \ldots \ldots \ldots \ldots \ldots \ldots 117$

Figure 12:

Organisational Commitment (OCQ' by Perceived Alternatives $\ldots \ldots \ldots 118$

Figure 13:

Job Satisfaction with Position by Perceived Alternatives $\ldots \ldots \ldots \ldots \ldots$

Figure 14:

Job Satisfaction Overall by Perceived Alternatives $\ldots \ldots \ldots \ldots \ldots \ldots$ 
Figure 15:

Path Analysis, Job Satisfaction Overall as an Intervening Variable ......95

Figure 16:

Path Analysis, Job Satisfaction with Promotion as an

Intervening Variable $\ldots \ldots \ldots \ldots \ldots \ldots \ldots \ldots \ldots \ldots \ldots . \ldots . \ldots 6$

Figure 17:

Path Analysis, Organisational Commitment as an Intervening Variable . . . 97

Figure 18:

Suggested Model of Turnover Intentions $\ldots \ldots \ldots \ldots \ldots \ldots \ldots \ldots 150$ 


\section{CHAPTER 1}

\section{INTRODUCTION}

The military has been defined as a 'greedy' institution - one which depends for its very existence on the total commitment of its members (Coser 1974:1). As a greedy institution, the military thus "seeks exclusive and undivided loyalty and attempts to reduce the claims of competing roles and status positions...Its demands on the person are omnivorous" (Coser 1974:6). That is not to say, however, that other organisations do not require or elicit loyalty and dedication to function effectively; the distinction, rather, is one of degree of the commitment demanded. Coser distinguishes the military from other social institutions in "the unusual pattern of demands it makes on service members and their families.. it is unique in the constellation of requirements" (Coser 1974:8). These requirements include the risk of injury or death; prolonged family separations; geographic mobility; and, in particular, the expectations and set of defined social behaviours based on traditions required of military families.

The military, though greedy, is not a total institution in Goffman's strict deiinition of the term. It is not "a place of residence and work where a large number of like-situated individuals, cut off from the wider society for an appreciable period of time, together lead an enclosed, formally administered round of life" (Goffman 1961:xiii). The military institution operating in isolation 
from the rest of society is neither an acceptable nor valid concept. This is particularly true of a military, like Canada's, which has not been engaged in confinct since the Korean War and has seen its role obscured in a 'sea of bureaucracy'. The military, as a social institution and as an integral part of Canadian society, must, by definition, be responsive to the norms and values of that society.

Problems arise, however, when the values and practices of the prevailing society are in conflict with and, in antithesis to, the set of traditions and values inherent in the military subculture. As a consequence, these values and practices are perceived as jeopardising the effectiveness of the military - an element which is an essential prerequisite to performing its role.

The Canadian military has undergone major structural changes in the past twenty years. Some of these changes include a period of de-segregation (some would say disintegration) in 1967 where the traditional three distinct services: Army, Navy and Air Force, became integrated into a force of one, and the subsequent re-segregation in 1982; the increasing number of single-parent and dual service families; human rights issues (the recruitment of humosexuals and the physically handicapped); and perhaps one of the more salient issues - the employment of women in non-traditional roles in combat and at sea. 
In additior, there exists an inherent conflict in the decision-making process of the military hierarchy which provides the guidelines for action based on the response to political and social influences, on the one hand and the implementation of these policies at the level of the individual in terms of behaviour and attitude change, on the other. Thus, the military can be perceived as being a socially responsive corporate citizen while at the same time having a 'rank and file' not fully accepting social change. It is suggested, therefore, that service members have conflicting expectations, where, on the one hand, they view the military as a distinct, unique organisation, while at the same time this institution is seen by society as indistinct from any other government department.

One way to resolve this conflict is to forego one's military values where the high degree of commitment demanded by the 'greedy' institution is no longer necessary and becomes less important than one's self interest. Gabriel defines this 'state' as "careerism" where the "system engenders values corrosive of any concept of the military as a special calling requiring special service and sacrifice...Military experts have been replaced by managerial tecl:nocrats who have little interest or feel for the human dimension of war" (Gabriel 1985:189). When speaking of the United States military Officer Corps, he describes them as the "entrepreneurial officer" whose self interest takes precedence over that of the membership and the institution itself. 
This is not to say that the Canadian military is at present in danger of losing its calling as a true profession. It is, rather, that there are, inherent within the organisation, those values and attitudes which could lend themselves to an erosion of the loyalty, dedication and commitment necessary to its efficient and effective operation.

Commitment of its members is an integral part of any organisation. By definition, it implies an emotional and behavioural attachment to the goals and values of that organisation. It is a concept of shared values, common purpose and corporate effort and is the basis of continued productivity. Hackett describes this feeling of commitment, within a military organisation, as "the clause of unlimited liability - the expectation that the soldier will keep his commitment even if it entails death" (1979:121).

In a comprehensive study of the Canadian military, Cotton (1980) gave evidence to suggest that this level of commitment has been compromised to what Janowitz called "pragmatic careerism - the military is no longer an isolated calling functioning to protect the honour of society. It is now a profession subject to all the vicissitudes of careerism in a bureaucratic setting" (Janowitz 1961:52). In commenting on the incompetence of the American military, Gabriel remarked: "the officer must know in his bones that his role as a military professional requires different values from those of the business executive... The military must relearn 
that its true profession entails $s_{\mathrm{r}}$-cial obligation and responsibilities" (1985:189). For the military, commitment is the 'glue' which holds it together; it serves to reinforce the loyalty, leadership, satisfaction and esprit de corps which comes about in belonging to the organisation.

Not only is there an intrinsic value of commitment to an organisation, there are also high costs associated with not having it. Turnover necessitates a continual process of recruitment, selection and training programs. These programs are expensive to maintain. For example, the Canadian Forces spent $\$ 48$ million for recruitment and selection programs in 1990/91. The cost of training each new recruit is \$3614 in Nova Scotia for English speaking students and \$7193 in Quebec for French speaking ones. A 4 year university program at a military college for one student costs $\$ 61,400$. The Navy will spend $\$ 41,100$ to train each Naval Officer (Maritime surface and sub-surface). This expense does not include the salary he/she receives whilst undergoing training. (Expenditure source: D Cost S April 91).

Turnover, particularly unforecasted voluntary attrition, is, consequently, expensive and a drain on an organisation's operating budget. This, together with the costs associated with the losses of productivity and a highly trained pool of human resources, are the negative consequences of turnover. A highly committed and satisfied work force significantly contributes to lessening the costs of turnover. 
The Navy has undergone significant changes over the past 10 years which has put considerable strain on the morale and confidence of its members. The lack of direction in Naval policy, cancellation of the nuclear powered submarine program and aging equipment are but a few. As German, writing on the history of the Navy remarked: "Canadians, except in time of open war and the raw threat of the fifties, have turned their backs to their navy and the sea..." (1990:325).

As a consequence, the pervasiveness of the social changes and their impact on the structure and role of the Canadian military, in general, and the Navy, in particular, makes a re-evaluation of the degree of organisational commitment among its members particularly timely and appropriate. To this end, this study examines organisational commitment and job satisfaction among a sample of Naval personnel and their influence on intentions to leave or stay in the Navy.

A comprehensive review of current theory and research, with respect to commitment and satisfaction within organisations, is provided in Chapter 2. A model of turnover intentions is presented which will be examined and tested within the context of this study.

Chapter 3 describes the research design and methodology adopted to carry out this empirical study of the Navy sample. A variety of statistical techniques are used to analyze the quantitative data collected and to test several propositions. 
In Chapter 4, the results of the data analysis are presented and are discussed in detail in Chapter 5. Empirical findings suggest that the turnover intentions model utilised in the study was conceptually inadequate in not considering all of the particular dynamics found within the research sample. Surprising, though not unexpected results were found with respect to rank (status) and service (tenure) within the sample of Naval personnel and their intentions to leave the Navy.

The final chapter presents conclusions and possible policy implications for the Navy, in particular, and the Canadian Armed Forces, in general. 


\section{CHAPTER 2}

\section{A REVIEW OF THE LITERATURE}

\section{Section 1 . Theoretical and Conceptual Framework}

\section{1 - Organisational Commitment}

There is a vast amount of literature on organisational commitment, much of which reflects the variety of theoretical perspectives from which commitment has been studied. Psychological and sociological views are restrictive and weakly defined. The management sciences, on the other hand, provide a more 'holistic' approach, incorporating the importance played by the individual within the organisation, as well as the part played by the corporation within the context, and as an integral part, of the society in which it operates.

The definitions of organisational commitment, too, reflect differences in theoretical emphasis and are classified broadly along a continuum from an individual-based perspective to one more socially determined. The former constitutes a moral, philosophical approach which suggests that commitment cannot be studied within the framework of the scientific method because it is an integral part of one's moral make-up. Concepts such as morality, responsibility, 
values and obligations are discussed within this context. The highly subjective and personal nature of commitment, defined in this way, makes the concept difficult to measure. That is not to say that the two approaches are mutually exclusive. Indeed, when the concept is comprehensively examined, there are both elements of moral, subjective commitment and those more socially determined included. The philosophical, more personal aspect, however, provides a dimension which precludes scientific enquiry.

Amitai Etzioni (1961) has identified three forms of involvement in the organisation; he does not use the term commitment. Moral involvement is a positive, high intensity orientation based on an internalisation of organisational goals and values. Calculative involvement is based upon a rational exchange of benefits and rewards (Steers et al 1981:4). Becker had earlier termed this aspect "side-bets or investments" (1960:32). Subsequent research by Baba and Jamal (1979) and Rusbult and Farrell (1983) expanded this notion of an exchange process even further. Alienative involvement encompasses a more negative orientation and suggests a non-voluntary compliance which is situation specific, as in prisons for example (Etzioni 1961).

In later literature, Sheldon (1971) used the terms involvement and commitment interchangeably. It may well be true that they are not conceptually different. There is, however, an element of degree of strength and stability over 
time which may differentiate one from the other. One may have job involvement yet not be committed to the organisation.

A more attitudinal approach was taken by Kanter who defined commitment as "the willingness of social actors to give their energy and loyalty to social systems; the attachment of personality systems to social relations which are seen as self expressive" (1958:499).

She views commitment in terms of a communion - individuals identifying with others to promote a 'we' sentiment. Mowday, also an attitudinal theorist, defined commitment as "the relative strength of an individual's identification with, and involvement in, an organisation" (1982:226).

The individualistic or psychological nature of the attitudinal approach to organisational commitment is narrow and restrictive. It downplays, but does not totally ignore, the role of the organisation and the characteristics of the work environment within which the individual functions, as well as the behavioural consequences which necessarily follow from this identification. Organisational commitment, therefore, is seen as a passive, static state of loyalty and attachment.

The behavioural approach on the other hand, views organisational commitment in terms of the related behavioural outcomes. It implies that 
behaviour is the reflective mirror of the attitude from which it originates.

Salancik, for example, defines commitment as "the binding of the individual to ivenavioural acts" (1977:121). Thus, commitment is inferred from how an individual behaves. This, however, is not necessarily a logical inference. Buchanan viewed commitment as: "the willingness of an employee to exert high levels of effort on behalf of the organisation and a strong desire to stay with the organisation" (1974:534). Consequently, negative behavioural outcomes, such as turnover, absenteeism and attrition, or their behavioural opposites, attendance, retention and performance, are seen as indicators which quantify 'how much' or 'how little' an individual is committed to an organisation.

Unlike the attitudinal approach, the behaviourists ignore the affective and cognitive input of the individual in determining or influencing the degree of commitment and loyalty he/she extends to the organisation. Consequently, the evaluative component of a member's norms, values and attitudes are dismissed as unimportant and are only inferred from the behavioural ouicomes which result.

More recent theorists have proposed an interactive approach which views organisational commitment as a process inter-linking an individual's values and attitudes with consequent commitment behaviour. Thus, attitudes and behaviour which determine organisational commitment, are not mutually exclusive but rather 
mutually reinforcing. Steers, Mowday and Porter for example, define organisational commitment as:

The relative strength of an individual's identification and involvement in an organisation. It is characterised by at least three factors: (a) a strong belief in and acceptance of the organisational goals and values; (b) a willingness to exact a considerable effort on behalf of the organisation; and (c) a strong desire to maintain membership (1977:46).

Thus, the internalisation of the goals and values of the organisation by an individual is indicative of, and inferred from, the 'level' of that individual's commitment.

Contrary to previous approaches, commitment is now seen as a dynamic process of linking the individual to the organisation through the mutually reinforcing and influencing characteristics of both. The interactional approach, therefore, combines aspects of both the attitudinal and behavioural theorists, where the individual and the organisation are equally important in determining the level of commitment. As a consequence, it is a more comprehensive, all encompassing theory of organisational commitment.

Steers and Porter developed a model of organisational commitment based on this theoretical framework which included what they termed 'antecedents' and 'behavioural outcomes' of organisational commitment. Piedictors (antecedents) of commitment include personal characteristics of the employee, such as age and 
education; characteristics of the job itself, such as task identity and variety; and work experiences, such as group attitudes and feelings of personal importance. Together, these determinants produce feelings of attachment (commitment) which, in turn, lead to certain behavioural sutcomes, including attendance, retention, job performance and intent or desire to remain with the organisation.

Although Porter and Steers (1977) were among the first to conceptualise a model of organisational commitment, studies which actually preceded their model did provide initial support for the concept, particularl; for the predictor (antecedent) variables. For example, Hrebiniak and Alutto (1972) found role stress to have a detrimental effect on organisational commitment; organisational ccmmitment was also found to be higher for those with higher education (Steers and Koch 1976); commitment was also shown by Hall and Schneider (1972) to be influenced by the degree of job challenge. The model by Porter and Steers also predicts that the behavioural outcome of high commitment will be low turnover. In an earlier study of psychiatric technicians, Porter, Steers, Mowday and Boulian had found that: "commitment to the organisation was clearly the most important variable in differentiating between stayers and leavers" (1974:606). Similarly, in a later study of bus drivers, Angle and Perry concluded that there was "an inverse relationship between organisational commitment and employee turnover" (1981:10). 
Porter, Crampon and Smith (1976) used a longitudinal study of retail managers to link organisational commitment and employee turnover. With riw exceptions, however, most of the research used correlational rather than longitudinal methods to study organisational commitment and its effects. This has important implications for the development of commitment over time.

One of the major criticisms in the study of commitment has been the lack of consistency in the definition of the concept. As a consequence, there has been a clear understanding of the 'outcomes' of organisational commitment such as turnover, absenteeism and attendance but contradictory evidence as to the determinants or 'antecedents' of commitment. Reichers (1985) compares the numerous antecedents studied to a "laundry list" -obscure, multi-faceted and varied. A summary of empirical research which has utilised the Porter and Steers model of organisational commitment is found at Appendix 1. The summary is an indication of the prolific use of the model.

Porter and Steers implied the notion of an exchange process in their model of organisational commitment. Exchange, in this context, means that the needs and goals of the individual are consistent with those of the organisation. It is assumed that when this interrelationship is congruent, commitment will increase. Conversely, if the goals of the individual and those of the oiganisation are at odds, 
then commitment would be predicted to decrease. This concept of exchange was adopted from earlier theorists: Becker (1960), Kanter (1968) and Salancik (1977).

Interactionist theorists have included an exchange dimension in their approach. Kahn, Wolfe, Quinn, Snoek and Rosenthal (1964) identified the importance of exchange, as an evaluative process, on the part of the individual who cognitively assesses the 'value' of the antecedents in terms of their importance to him/her, which in turn is reflected in his/her degree of commitment and subsequent behaviour. This errhange (evaluative) process, then, acts as a 'filtering' system and does much to explain individual differences of organisational commitment when all other factors are held constant. This process has been conceptualised in the "role taking model of the commitment process" developed by Kahn et al (1964:186).

Similar to the later Porter and Steers approach, the role-taking model combines the characteristics of the ir:dividual with those of the work and organisational setting as determinants (antecedents) of organisational commitment. Within this model, "a manager (employee) may use perceived benefits and costs in an exchange paradigm to evaluate multiple influences that structure his decisions about ongoing activities" (Stevens, Beyer and Trice 1978:392). 
As a consequence, organisational commitment is defined in terms of the accrual of side bets or 'investments'. Becker (1960), for example, suggested that the more one has at stake in an organisation or the more one has 'accrued' and thus could lose by leaving the employing system, the greater the personal commitment to the organisation (Hrebiniak and Alutto 1972). Investments or side bets are not only economic ones (pay, pensions) but more importantly, psychological and social ones (feelings of importance, job challenge, leadership, social interactions). Consequently, the individual's cognitive evaluation of the relative worth of remaining with the organisation and hence his/her degree of organisational commitment, is influenced by family concerns; perceptions of career advancement; opportunities for other employment; or proximity to pension entitlements. Thus, an individual may be committed to an organisation because of the 'benefits' associated with that membership and/or when the 'costs' associated with non membership are considered too high. The internalisation of the norms and values of the organisation by the employee is also assessed as an investment. These investments bring with them certain rewards and benefits. "The greater the rewards an individual has received or is perceived to be receiving, the greater the degree of his commitment" (Grusky 1965:491).

Within a military context, Rawlinson (1978) studied Australian Air Force technicians who were within a few years of pension entitlements. He found that they were reluctant to leave the service even when they had low job satisfaction. 
Thus, proximity to pension acted as a "side bet" to remain within the organisation. More recently, Angle and Perry contended that: "an individual's level of commitment to a given target is a function of actual or anticipated rewards and past investments - material and psychological" (1983:3).

Rusbult and Farrell sought to combine traditional exchange theories with those of organisational commitment and job satisfaction in an attempt to quantify the outcome of turnover. Specifically, they proposed that the higher the rewards and the lower the costs offered would lead to greater job satisfaction. Commitment, on the other hand, was a more complex phenomenon. Consequently, they defined commitment as the result of: "... increases in job rewards, decreases in job costs, increases in investment size and decreases in alternative quality or alternate job" (1983:430). They further contended that turnover was a consequence of decreases in levels of commitment. In an attempt to validate their model, Rusbult and Farrell studied junior staff accountants and nurses. Not surprisingly, they found that: "greater job rewards and lower job costs induce greater employee satisfaction. Greater job commitment is encouraged by higher rewards, lower costs, greater investment of resources and poorer alternatives" (1983:436).

Exchange or investment models of organisational commitment offer explanations as to how antecedents such as age, status, length of service, for 
example, influence the degree of organisational commitment. Thus, initial entry employees have lower levels of commitment and, it is proposed longer serving employees have higher levels of commitment for "during early stages at a job, job costs are minimal and investment size is small but as time passes these factors become more important determinants of worker perceptions" (Rusbult and Farrell 1983:437).

Although the multi-faceted and complex nature of organisational commitment has been recognised, insufficient attention is paid to the process of commitment implied in the interactionist approach to the concept. Later work by Mowday, Porter and Steers, however, addressed this concern. They suggested a "feedback loop" in which "antecedents and outcomes of commitment do not act merely as a one way flow process but rather changes in either, such as changes in the work environment, can enhance or ameliorate the desire to leave or the act of turnover" (1981:34). Thus, an individual who become'; dissatisfied may initiate changes to alter his/her satisfaction level which in turn changes leave or stay intentions.

Rusbult and Farrell (1983) refer to the "process of change" within the job rewards, costs, investments and alternatives framework which discriminates between those who stay and those who leave. Similarly, Reichers in his study of mental health care professionals concluded that: "findings suggest that 'sunk' 
costs or structural antecedents io commitment may not develop until late career stages" (1986:513). He implied that these costs may change over time.

More recently, theorists have offered a re-conceptualisation of organisational commitment in an attempt to provide a comprehensive definition of the construct. Morrow, for example, suggested that the term commitment is no longer appropriate in that: "the commitment construct should be dismantled to reflect its apparently multiple foci" (1983:489). Similarly, Mowday et al suggest that: "few studies have simultaneously examined the impact of multiple commitments of employees" (1981:36).

The notion of multiple commitments was studied by Oliver who contended that: "members of social movement organisations can show a high commitment to many criteria but regard their stay with the organisation as a transitory one. Here, the primary commitment targets are not the organisations per se but rather the goals and values which they embody" (1984:30).

Multiple commitments are evident within professional occupational groupings. Lachman and Aranya, in a study of Certified Professional Accountants, argued that: "professional commitment can be viewed not only as preceding commitment to a particular organisation but also affecting it... The two may be consistent with each other or even interdependent..." (1986:290). Consequently, 
having many commitments may not necessarily mean less commitment to the organisation since they may not be in conflict with one another but may, in fact, be mutually reinforcing.

Methodological weaknesses in commitment research only serve to reinforce the highly complex and complicated nature of the concept. Models discussed, though relevant and valid, lack a: all encompassing, comprehensive understanding of the commitment process. As Reichers contends: "organisational commitment, like job satisfaction, may be both a general and multi-faceted construct...Future efforts directed at understanding its component parts may result in increased sophistication and progress in commitment research" (1986:513).

In the present study, the concept of organisational commitment will be viewed as instrumental within the context of turnover behaviour and the significant associated costs of leaving or having intentions to leave an organisation.

\section{2 - Job Satisfaction}

A second important concept which has been studied extensively within the framework of turnover behaviour is job satisfaction. It is also instrumental to the model of turnover utilised in this study. 
Locke defined job satisfaction as:

The pleasurable emotional state resulting from the appraisal of one's job as achieving or facilitating the achievement of one's job values. Job satisfaction and dissatisfaction are a function of the perceived relationship between what one wants from a job and what one perceives it is offering (1969:316).

Thus, job satisfaction rests on the congruence between an individual's expectations of the job and the reality it offers.

Job satisfaction, like organisational commitment, has inherent within it an assessment component by the individual - the aspect of a cognitive evaluation of the expectations (investments, rewards) he/she receives from the job itself. As Steers and Rhodes point out: "a major influence on the extent to which employees experience satisfaction with the job situation is the values and expectations they have concerning the job" (1978:396). This evaluative process of job satisfaction is determined by personal, job and organisational characteristics in much the same way as is organisational commitment.

Similarly, Homans (1958) wrote in terms of the "principle of distributive justice" involving the balance between an individual's rewards and investments. Thus, satisfaction results when individuals determine that they have been suitably rewarded for the amount of time and effort they have put into their job. In studies by Cooper and Payne (1965); and Katzell (1960), age and length of service were linked with positive evaluations of the job situation and it was found that 
older and longer serving employees value and expect certain considerations (rewards) because of their seniority.

Consequently, the cognitive assessment of personal, job and organisational factors is as much an important deter:ninant of job satisfaction as it is of organisational commitment. The importance of the individual's evaluative process in the determination of job satisfaction cannot be understated. Locke defines this evaluation as: "a process of subjective psychological measurement in which a value is the standard" (1969:315). Job satisfaction, like organisational commitment, therefore, is an interactive process and "levels of job satisfaction are functions of the range of specific satisfaction and dissatisfaction a member experiences with respect to the various dimensions of work" (Koch and Steers 1978:127).

Steers and Rhodes (1978) suggested a theoretical model of job satisfaction which is similar to the Kahn et al (1964) model of organisational commitment. It related job satisfaction to employee turnover. A more recent model by Mobley (1979) linked organisational, individual and economic - labour market variables as determinants of job satisfaction which in turn are precursors of turnover intentions. In a study of hospital employees, Mobley, Horner and Hollingsworth provided support for the model when they found that: "both dissatisfaction and the probability of finding acceptable alernatives contribute to eliciting thoughts of 
quitting" (1979:412). Similarly, a longitudinal study of Marine Corps enlistees by Youngblood, Mobley and Meglino concluded that: "satisfaction demonstrated its ability to differentiate among criterion groups and exhibited systematic and predicted changes over time" (1983:513). Martin studied a sample of marketing firm employees and found that job satisfaction had a direct negative effect on the intent to leave. He concluded that: "as job satisfaction, upward mobility and age increase, intent to leave decreases" (1979:322).

Mobley's model of the turnover process is analogous to that of Porter and Steers'. The most salient and important difference is that the former links job satisfaction with turnover intentions and the latter links organisational commitment with turnover. Both models have inherent within them a cognitive, evaluative (exchange) component of the individual in terms of the degree to which his/her expectations are met by the organisation. Thus, "individual differences in perceptions, expectations and values are explicitly recognised" (Mobley 1977:239).

In addition, both models acknowledge the complexity of the interrelationships among the variety of factors involved in the turnover process. Variables such as age, tenure, status, organisational policies and reward systems, 
among many others, serve to influence the degree of turnover within organisations. As Mobley et al point out:

The antecedents of satisfaction and attraction (of alternatives) are considered to be organisational variables as perceived by the individual; economic variables related to the availability of alternatives as perceived by the individual; and individual-level occupational and personal variables as they influence individual values, perceptions and expectations (1979:520).

The multivariate nature of the turnover process has been recognised in numerous studies. Arnold and Feldman, for example, in their study of accountants, found that turnover was "significantly influenced by age, tenure, perceived job security, job satisfaction, organisational commitment and intention to search for alternative positions" (1982:259). What has been consistently determined, however, is that these individual, organisational and externa! antecedents/determinants have an indirect influence on turnover. Consequently, in both the Mobley model and that of Porter and Steers, job satisfaction and organisational commitment, respectively, act as intervening variables within the turnover process.

Martin (1979) in his study of the members of a business organisation concluded that job satisfaction had a direct negative effect on leave intentions, whereas age, gender and work routinisation all had indirect positive influences. Michaels and Spector suggest that there exists a "possible causal chain from individual and organisational factors through job satisfaction and commitment, 
through intention and finally to turnover" (1982:58). Williams and Hazer, using data from Michaels and Spector's (1982) study of health facility employees found that:

Variables describing personal characteristics and the work environment have no direct impact on turnover intentions... This finding substantiates the importance of satisfaction and commitment as intervening variables in models of turnover (1986:228).

This research also found support for the importance of the congruence between individual perceptions, evaluations and expectations with those of the organisation - an exchange process. The authors contended that: "these factors (personal, job and organisational characteristics) may influence commitment only indirectly. In other words, through a process of the evaluation of costs and benefits, individual needs and desires are satisfied and the resulting affective state becomes associated with the organisation..." (Williams and Hazer 1986:229-230).

\section{Job Satisfaction and Organisational Commitment}

Given the common characteristics inherent in the concepts of job satisfaction and organisational commitment: antecedents, interactive processes, evaluative component and behavioural outcomes, is it valid, therefore, to assume that the two are related in some way? Research has suggested that organisational commitment and job satisfaction are two distinct concepts but not totally 
unrelated. Certainly there is some conceptual overlap and it is hypothesised that evidence will suggest an empirical overlap as well.

The attitudinal and behavioural components of organisational commitment suggest that job satisfaction may be an important aspect of commitment since it has, by definition, an affective, attitudinal characteristic. Baba and Jamal (1979) studied organisational commitment among Canadian blue collar production workers and found that job factors such as variety, skill level and having 'slack' periods were positively correlated with organisational commitment. Porter, Crampon and Smith speculated that: "commitment may be a more global and stable evaluative linkage between the employee and tire organisation which includes job satisfaction as a component" (1976:88). Job satisfaction, consequently, refers to the emotional response one has to the characteristics of the job within the organisation rather than the attitudes (attachment) one has towards the organisation itself. It is conceivable, therefore, that one may be highly satisfied with one's job and yet, not fully committed to the organisation or vice versa.

Another distinguishing feature of job satisfaction and organisational commitment is that of time; that is, length of service. Researchers have suggested that organisational commitment develops slowly but consistently over time and consequently, becomes a more enduring type of response. Mowday, Steers and 
Porter suggested that: "the commitment process may be characterised by increasing consistency between attitudes, perceptions and behaviour as length of service increases in the organisation" (1981:29). Job satisfaction, on the other hand, may be tied to the challenge, scope and conflict of a particular job - a job which may, in itself, be transitory in nature. Mowday et al contend that:

Although the two variables would be expected to be highly correlated within a given sample, it is, at the same time, possible to imagine an employee who holds positive beliefs about, and is attached to a specific organisation and its goals and values, but is unhappy with the experience of certain aspects of a specific job within that organisation and vice versa (1981:34).

In an extensive study of job satisfaction and organisational commitment, Glisson and Durick (1988) found that both job satisfaction and organisational commitment had common predictor variables which included both personal (age, education) and work characteristics (role ambiguity, variety). Equally important, they concluded that: "satisfaction and commitment are correlated but conceptually separate attitudes that are related differently to dimensions of the same work context" (1988:76). Research conducted by Williams and Hazer (1986) supported the contention that satisfaction and commitment were intervening variables between the determinants (demographic characteristics and work factors) and turnover intentions. More importantly, their study suggested a causal link between job satisfaction and organisational commitment in that: "personal and organisational characteristics influence only satisfaction directly and influence commitment indirectly through their impact on satisfaction" (1986:228). 
Contrasting results were found by Farkas and Tetrick (1989) who, in a study of Navy enlisted personnel, using both organisational commitment and job satisfaction as intervening constructs, found that the relationship between the two may be cyclical or reciprocal. They contended that in the initial entry stage, the linkage may be reciprocal. As one stays with the organisation longer, the relationship may become cyclical. Consequently, attitudes such as satisfaction, commitment and expectations may be adjusted to be consistent with the intention to stay or leave. (Farkas and Tetrick 1989). Michaels and Spector (1982) and Porter et al (1982) also suggested that there was a conceptual linkage between job satisfaction and organisational commitment but did not discuss what this relationship was.

Research findings indicate that there is a more complex process within turnover intentions. The fact that job satisfaction and organisational commitment may be reciprocally or cyclically related acknowledges an ever changing, dynamic nature to turnover behaviour. As Williams and Hazer contend: "...those (empirical turnover studies) which fail to include both satisfaction and commitment should be viewed cautiously...Ignoring the causal relation between satisfaction and commitment would also demonstrate to represent a serious limitation" (1986:230). 


\section{4 - Intentions Versus Tumover Behaviour}

A major component of the Mobley model of turnover behaviour and the later work of Porter, Steers and Mowday (1981), is the distinction between the intentions to leave or stay and actual turnover behaviour. Based on the work of Ajzen and Fishbein (1973), the model suggests that an individual's intention to act is a precursor, if not the precursor to the actual behavioural outcome. This "theory of reasoned action" (Ajzen and Fishbein 1973), consequently, predicts behavioural responses from the attitudes (intentions) shown by the individual.

Thus, the intention to stay or leave predicts the behaviour to stay or leave. In terms of the Mobley model; and the Porter and Steers' model, therefore, the degree of job satisfaction or organisational commitment, respectively, would influence the individual's intentions to stay or leave which in turn would influence actual turnover behaviour.

Empirical studies, most notably those of Newman (1974); Marsh and Mannari (1977); Mobley et al (1978); and Arnold and Feldman (1982) concluded that intentions to leave or stay were not only related to actual turnover behaviour but would, by necessity, precede turnover. In addition, Mowday, Koberg and McArthur in a study of hospital employees concluded that: "the best predictor of turnover was the intention to stay in the organisation" (1984:90). 
The importance of intentions as an intervening variable between the affective and behavioural components of the turnover models, lends credence to the significant role the individual's perception and cognitive evaluation of the work situation plays in his/her ultimate decision to stay or leave an organisation. This evaluation would include an assessment of the benefits of staying and the costs of leaving in light of the present or potential investments made by the individual with his/her job and the organisation itself. Consequently, "if the costs of quitting are high and/or the expected utility of search is low, the individual may re-evaluate the existing job (resulting in a change in job satisfaction), reduce thinking of quitting and/or engage in other forms of withdrawal behaviour" (Mobley 1977:238).

It is not the intention within the scope of this research to examine actual turnover behaviour but rather, the intentions to stay or leave.

Given this theoretical framework, a model of turrover intentions is proposed (Figure 1). 


\section{Fiqure 1}

\section{Model of Turnover Intentions}

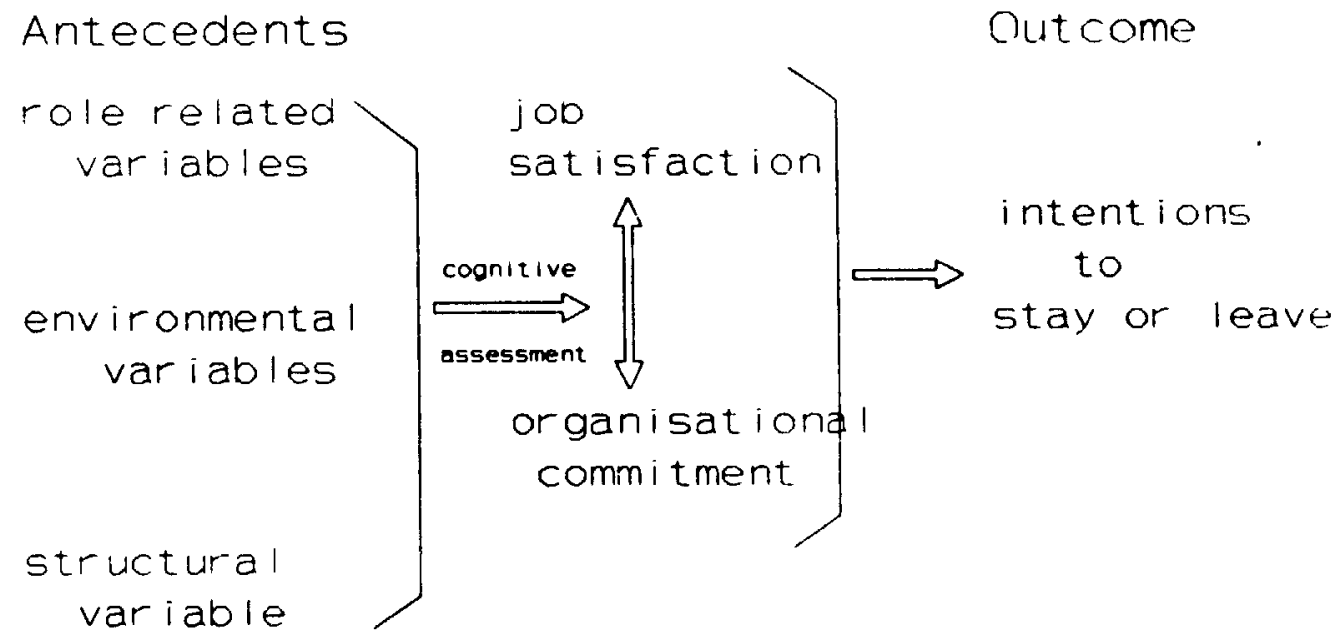

\section{Section 2 - Conceptual Framework and Causal Linkages}

\section{5 - The Theoretical Model}

Role - related antecedents will be defined by two variables: (1) rank or status and (2) tenure or length of service. Environmental variables will be defined by environmental pull or perceived employment alternatives outside the organisation. Structural variables will be defined by organisational size. Consequently, the theoretical framework for the present study is provided (Figure 2). 
Figure 2

Model of Turnover Intentions for the Study

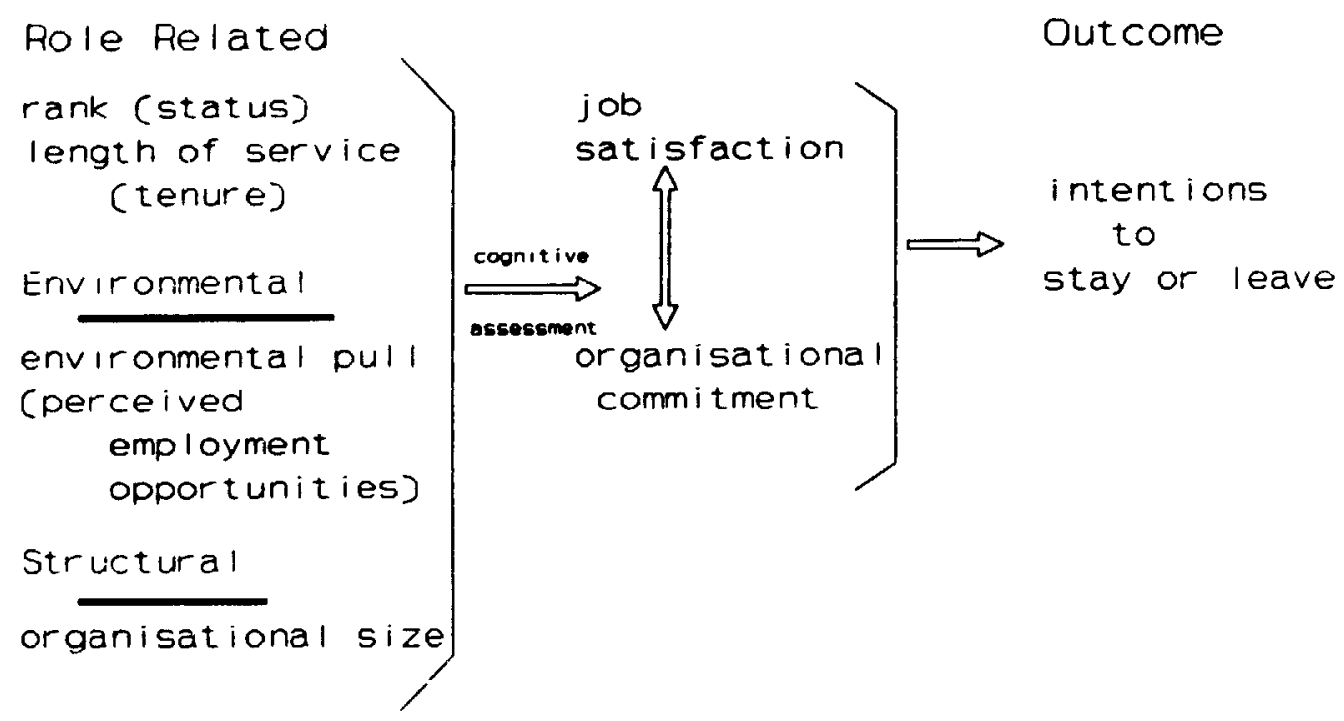

\section{6 - Rank (Status) and Organisational Commitment}

Within a military context, the concept of organisational commitment has been operationally defined along an "institutional-occupational" continuum. High, moderate and low levels of commitment, defined by Porter and Steers (1977) on the basis of the Organisation Commitment Questionnaire (OCQ), were related by Moskos (1977) to this continuum. Thus, high commitment is defined as "institutional" commitment; low commitment is defined as "occupational" commitment; Cotton (1980) added a third, moderate commitment which he defined as "ambivalent" commitment. 
Conceptually, institutional commitment within the military may be viewed

as:

(1) the commitment of members to serve the organisation; (2) a willingness to devote oneself to the organisation on a 24-hr basis; (3) organisational objectives take precedence over self interest; and, (4) total dedication of the individual to the organisation (Moskos 1977:42).

On the other hand, low or occupational commitment is the conceptual opposite, viewing the military not as a distinct organisation but rather one which is similar to those of the civilian sector. Thus, the military profession for those with low commitment is a job like any other, where, as Segal points out: "management has been substituted for leadership, human resources for the soldier, regulations and contracts for traditions and cost effectiveness for combat effectiveness" (1986:352). It should be noted that, within a military context, the occupation is the organisation, as well as the profession. "Nuciari (1985) coittends that the true nature of the military profession is...jts link with an organisation that, due to its standing within the social structure, becomes an institution" (Caforio 1988:59).

Cross cultural military studies have confirmed the attitudinal continuum of Moskos' model and the positive, direct relationship between rank and organisational commitment: Lucas (1973), Harries-jenkins (1978), who studied the Royal Air Force (RAF); and Gatinaud (1980) who found a similar trend in the French Armed Forces (Cotton 1980). In a study of the Canadian military, Cotton found that: "the higher the rank level, the greater the support for the institutional 
model and that this support is positively related with commitment" (1980:353). Similarly, Maillet studied a sample of officer cadets at College Militaire Royale (CMR) using Cotton's model; the results supported previous findings. In addition, he found that: "the institutional-occupational dimensions of military orientation were not necessarily exclusive or separate from one another. On the contrary, the majority tested appeared to manifest both perspectives" (1986). Officer cadets, however, have limited experience and time in the military. It is doubtful, therefore, whether their limited experience would reflect a true institutional orientation in any case. Stahl, Manley and McNichols (1978), in studying the career intent of members of the US Air Force, also supported the linkage between rank and organisational commitment.

In terms of the theoretical model proposed, achieving higher rank (status) within an organisation is seen as a reward and as a positive inducement to expand the scope and challenge of one's employment associated with advancement in the hierarchy. Sheldon, in her study of $\mathrm{PhD}$ scientists, found a strong positive relationship between position (managerial level) and organisational commitment. She explained that: "position is an investment because higher positions are supervisory positions... Supervisory positions are a reward from the organisation and are an indication that his work is being recognised which should enhance his identification with the organisation" (1979:145). Thus, it would appear that as an 
individual's status in the organisation increases, his/her investment to remain increases, which results in a greater attachment to the organisation.

\section{7 - Rank (Status) and Job Satisfaction}

In a military organisation, an increase in rank (status) by promotion, generally brings with it a concomitant expansion of responsibilities, authority and challenge. Thus, rank is not only an advancement within the hierarchy, but it also represents job enhancement. It would, therefore, be expected, though not definitive, that as rank increases, so too, would job satisfaction.

In a study by Marsh and Mannari (1977) of lifetime commitment among Japanese electrical workers, it was found that lower status workers, with poor perceived chances of promotion, had low job satisfaction and were more likely to leave the company than those with higher status and higher job satisfaction. Similarly, Stahl, Manley and McNichols (1978) found a positive correlation between seniority and job satisfaction and career intent. Cummings and Elsami (1970), in a study of company managers, suggested that role identity and job level have stronger relationships to managerial satisfaction than company size. These findings were supported in a similar study by Lee, Mueller and Miller (1981). 


\section{8 - Length of Service (Tenure) and Organisational Commitment}

Research supports the causal link between length of service (tenure) and organisational commitment (cf.p.18). Generally, as length of service increases, the individual becomes more identified with the organisation and is reluctant to leave. The individual's attitudes and behaviour become more congruent with those of the organisation. Length of service involves the accumulation of investments and rewards, such as seniority and experience, which may make it more difficult for the employee to leave. Hrebiniak and Alutto suggested that: "time invested becomes a valued resource in itself, while the privileges associated with length of service make it easier to derive additional organisational rewards" (1972:566). These investments and consequent rewards reinforce the employee's attachment to the organisation. In their study of teachers and nurses, the relationship between tenure and commitment was supported. "Organisational commitment exhibits a positive relationship with total years spent in the organisational role. Furthermore, the greater the experience or seniority the less the expressed desire to leave" (Hrebiniak and Alutto 1972:556).

Mowday, Steers and Porter suggested that one of the best predictors of organisational commitme it was tenure. Length of service influences the degree of commitment in a number of ways: 
(a) it increases the likelihood that employees will receive more challenging job assignments and greater intrinsic rewards; (b) it increases investments of the employee making it difficult to leave voluntarily; (c) it increases social involvement within the organisation; and, (d) it may serve to decrease the employee's job mobility (1981:27).

Longitudinal studies of organisational commitment have supported the causal relationship between tenure and organisational commitment. Consequently, as length of service increases, it would therefore be predicted that organisational commitment would increase.

Moreover, empirical research has linked tenure with turnover intentions, suggesting that the two are inversely related (Mobley, Horner and Hollingsworth 1978; Waters, Roach and Waters 1976). Arnold and Feldman in studying members of the accounting profession concluded that: "turnover is significantly influenced by age, tenure, overall job satisfaction...." (1982:359).

\subsection{Length of Service (Tenure) and Job Satisfaction}

The relationship between length of service and job satisfaction is not as

direct as the causal links in the concepts discussed previously. Herzberg, Mausner, Peterson and Capwell (1957) suggested a U-shaped relationship between tenure and job satisfaction - with high levels of satisfaction within the initial years of employment; moderate levels within the middle years and increasing again to high levels of satisfaction in latter years. 
In their study of Navy enlisted men, McDonald and Gunderson (1974) found a direct relationship between length of service and job satisfaction. However, this relationship was moderated by the 'kind' and characteristics of the job itself. Jobs that were routine and boring were found to be less satisfying than those that were challenging and varied. Thus, what seems to be most important here, perhaps more so than the previous causal relationships, is the cognitive evaluation by the individual of the rewards he/she is receiving from the job in relation to the investments he/she has made in it. If an individual has spent a number of years in the organisation without receiving perceived rank or advancement or job variety and challenge as expected, then it would be conceivable that he/she would become dissatisfied. One would expect then, that a member who has spent 20 years in the same or similar positions would be less satisfied than one who has spent only 2 to 3 years in a like position. This "positional tenure" as defined by Stevens, Beyer and Trice (1978) may give rise to relative perceptions of costs associated with career stagnation. However, as length of time in the organisation increases, the individual becomes "locked in" when the costs of leaving become too high. Consequently, his/her expectations are re-evaluated to a more realistic level and given the career restraints, are perceived now as being more attainable.

Bateman and Strasser suggested, for example, that: "job satisfaction depends largely on the opportunity to use a variety of s'ills" (1984:108). Without 
the perceived opportunity to use these skills, satisfaction then would be expected to decline until cognitive assessment of other factors, such as family; proximity to pension entitlements; and outside interests, forces the individual to re-evaluate his/her expectations.

In a military organisation, it is not inconceivable that a member could spend an inordinately long time in one rank without receiving job enhancement or challenge. In this way, Herzberg's U-shaped relationship between length of service and job satisfaction would be expected. Tenure, as Stevens, Beyer and Trice point out, becomes a double-edged factor: "it may connote stability and accrued investments. However, it may also point to decreased opportunity elsewhere and reduced mobility within the organisation itself" (1978:393). That is, until a cognitive reassessment takes place, in which case, it would be expected that job satisfaction would then increase.

The causal link between tenure, job satisfaction and turnover was suggested by Mobley et al (1978). They concluded that tenure had an indirect effect on turnover intentions through satisfaction. Michaels and Spector studied employees of a mental health care facility to test the model that age and tenure influence job satisfaction which in turn would lead to intentions of quitting. Their findings suggested: "a possible causal chain from individual and organisational factors, 
through job satisfaction and commitment, through intention and finally to turnover" (1982:58).

Consequently, satisfaction, like organisational commitment, may change over time lending further credence to the fact that the linkages are dynamic, ever-changing ones.

\subsection{0 - Environmental Pull, Oreanisational Commitment, Job Satisfaction and Tumover Intentions}

Bluedorn defines environmental pull as: "the number and quality of unoccupied roles in the organisation's environment: the greater the number and the higher the quality, the greater the environmental pull" (1979:185). It is a similar concept to extra-organisational alternatives. In the context of this study, environmental pull will refer to those opportunities outside the organisation (military) perceived by the individual as attractive employment alternatives. Bluedorn hypothesised that the greater the environmental pull, the greater the propensity to leave the organisation. From a large sample of Army officers, he concluded that: "environmental pull had an indirect effect on turnover through the intervening variable satisfaction and that satisfaction had the anticipated direct effect on turnover intentions" (1979:194). In addition, he found that environmental pull was negatively related to satisfaction which, in turn, was inversely related to turnover intentions. 
The interaction between satisfaction and environmental pull indicated that: "satisfaction should have a much stronger negative relationship with turnover at high levels of environmental pull than at low levels" (Bluedorn 1979:194). Thus, the greater the availability and attractiveness of extra-organisational employment opportunities, the more likely the individual will have intentions to leave. Bluedorn suggests that the high amount of variance is explained by this interaction because leaving the Army is leaving both an organisation and an occupation.

Mobley included the concept of employment alternatives, based on the work of March and Simon (1958), in his later model of the turnover process. Conceptually, he proposed that: "it is not merely the visibility of alternatives but the attraction of alternatives and the expectancy of attaining the alternatives that are most salient" (1979:519).

Steers, Mowday and Porter in their comprehensive model of turnover behaviour included the concept of alternative job opportunities as a determinant of individual expectations. They suggested that: "if few alternative job opportunities exist, the employee would be less likely to leave the organisation" (1981:23). Whether this 'locked-in' feeling results in greater satisfaction or commitment, either to the job or to the organisation is, however, questionable. 


\subsection{1 - Orzanisational Size Oreanisational Commitment, Job Satisfaction and}

\section{Turnover Intentions}

Few studies have examined the relationship between organisational size, defined as the total number of full-time employees, and job satisfaction, commitment and turnover. Stevens, Beyer and Trice (1978) found a small but negative relationship between the size of the organisation and commitment of its employees. Similarly, Curry et al (1986); Baba and Knoop (1987) found a negative correlation between size and job satisfaction. Less turnover, therefore, would be found in smaller organisations. It is suggested that smaller organisations enhance commitment and satisfaction by allowing for more cohesive and manageable work groups and by facilitating social interaction among all managerial levels.

However, caution must be exercised where these results are interpreted. Organisation size, in itself, may not be the significant factor. It may be the structure of the organisation, in terms of centralisation and locus of control, as well as specific communication patterns which are the important factors rather than merely the size of the organisation. 


\subsection{2 - Orranisational Commitment, Job Satisfaction and the Intentions to Leave}

or Stay

The causal link between organisational commitment and job satisfaction, as predictors of intentions to stay or leave, has been supported in numerous research studies. One, by Porter, Steers, Mowday and Boulian of psychiatric technicians, suggested that: "stayers expressed higher levels of commitment and job satisfaction than did leavers" (1974:607). In addition, organisational commitment was a better predictor of turnover than job satisfaction.

Koch and Steers (1978) found a consistent, if moderate relationship, between satisfaction and intent to remain with an organisation, as did Taylor and Weiss (1972). Similarly, Marsh and Mannari (1977), in studying Japanese electrical workers, found that employees were more likely to leave if they had lower status in the organisation and their satisfaction was low. Anderson and Milkovich examined the propensity to leave amorg three occupational groups: professional, managerial and technical and found that: "job satisfaction was significantly associated with the individual's intentions to ieave for all three groups" (1980:289).

Stumpf and Hartman conducted a longitudinal study of 85 university graduates which measured the degree of organisational commitment and 
withdrawal intentions. They found that: "intention to quit was the direct result of two variables: organisational commitment and work satisfaction. The correlation between them (the two variables and leave intentions) was negative and significant" (1984:325).

It wouid be expected, therefore, that the more organisationally committed an individual is; the more he/she expresses job satisfaction; the more the accrued investments and rewards; and consequently, the less likely the individual would have intentions to leave the organisation.

\section{Section 3 - Conceptual Paradigm}

It is anticipated that the conceptual link beiween organisational commitment, job satisfaction and turnover intentions would be as follows:

\section{Organisational Commitment}

High Low

'ob

$\underline{\mathbf{S} \boldsymbol{z} \text {.sfaction }}$

High $\begin{gathered}\text { Most } \\ \text { Negative }\end{gathered}$

Low ? $\begin{gathered}\text { Most } \\ \text { Positive }\end{gathered}$

Thus, it would be hypothesised that ihose having high levels of job satisfaction and high levels of organisational commitment would be most unlikely 
(negative) to have intentions to leave the organisation. Conversely, those with low levels of job satisfaction and low levels of organisational commitment would be the most likely (positive) to have intentions to leave. The interesting and, as yet, undetermined outcome, is for those individuals who have low satisfaction, high commitment or high satisfaction and low commitment and the effect it has on their intentions tn leave or stay.

Blau and Boa: conceptualired organisational commitment and job involvement. Job involvement, like satisfaction, is on affective response (attitude) one has towards one's job. They contend that satisfaction is an integral part of any decision to withdraw from the organisation. Furthermore they suggest that: "background empirical research supports the positive links among job involvement, organisational commitment and job satisfaction" (1987:294). High job involvement, by definition, implies satisfaction, whereas low job involvement implies dissatisfaction. Similar to the paradigm given previously, their conceptual framework consisted of four cells with each cell predicted to have a different impact on turnover. These celis are:

(a) cell 1 - high job involvement high organisational commitment 
Individuals in this cell identify strongly with the organisation and would exert a high level of personal task related effort to their jobs. Blau and Boal call them "institutionalised stars". They would be least likely to have intentions to leave the organisation.

(b) cell 2 - high job involvement low organisational commitment

Individuals in this cell consider work to be very important to them but do not identify with the organisation itself. "Such employees will exert a high level of individual task - related effort but will not show much group maintenance effort." (Blau and Boal 1987:295). They are referred to as "lone wolves". Satisfaction, therefore, is derived from the work itself and consequently, it is proposed, they would be easily attracted to perceived quality alternatives from outside the organisation. Turnover intentions would, therefore, be high.

(c) cell 3 - low job involvement

high organisational commitment

Individuals in this cell consider that their work is not especially important to them $\mathrm{bit}^{+}$they strongly identify with the organisation. 
Blau and Boal term these individuals "corporate citizens". They conform to the organisation while at the same time carry out their assigned tasks and roles. These individuals are less likely than "lone wolves' to ieave the organisation voluntarily.

(d) cell 4 - low job involvement low organisational commitment

Individuals in this cell consider neither work nor the organisation important to their self-image. These persons are called " apathetic employees". In accordance with the Blau and Boal conceptualisation, "their attachment and compliance with organisational expectations/norms is based on calculative judgements. They would be most sensitive to...the availability of othe1 opportunities in decisions to withdraw" (1987:297). Thus, these employees would be, by definition, the most likely to leave the organisation.

The conceptual paradigm, therefore, based on Blau and Boal (1987) model would be: 


\section{Organisational Commitment}

High Low

\begin{tabular}{|c|c|c|c|}
\hline $\begin{array}{c}\text { Job } \\
\text { Latisfaction }\end{array}$ & High & $\begin{array}{l}\text { Institutionalised } \\
\text { Stars }\end{array}$ & Lone Wolves \\
\hline & Low & $\begin{array}{l}\text { Corporate } \\
\text { Citizens }\end{array}$ & $\begin{array}{l}\text { Apathetic } \\
\text { Employees }\end{array}$ \\
\hline
\end{tabular}

Moskos' (1977) institutional - occupational one dimensional continuum is analogous to the above conceptualisation by Blau and Boal. It is significantly different, however, in that Moskos examines only one concept, that of organisational commitment. Institutionals are defined as those individuals who have sacrificed personal interest to those of the organisation, while occupationals are those who rather serve their own interests first. Cotton, in his study of the Canadian military, added a third concept, that of ambivalents who are "those individuals who do not express a clear preference for either of the extreme models of military life" (1980:343). In an empirical examination of the Moskos model, Stahl, McNichols and Manley found that: "the institutional orientation was positively associated with career intent, seniority and job satisfaction, whereas the occupational orientation was negatively associated with these criteria" (1978:265). In other words, the more senior, in terms of rank and length of service and the more satisfied with one's job, the more likely the individual will be committed to the organisation and, to extend it further, the less likely the intention to leave. 
Consequently, in examining Blau and Boal's model, those cells which involve high organisational commitment (cells 1 and 3) would be termed "institutionals" and those which have low organisational commitment (cells 2 and 4) would be called "occupational". "Ambivalents" would be those individuals who are between the two extremes on both measures of job involvement and organisational commitment.

The above conceptualisation, therefore, would propose that the turnover intention continuum to be as follows:

$\begin{array}{ccc}\text { high OC } & \text { likely } & \text { low OC } \\ \text { low JS } & & \text { high JS }\end{array}$

high $\mathrm{OC}$ low OC

high JS low OC

\section{Section 4 - Propositions}

Based on the foregoing theoretical and conceptual framework, the following propositions are presented for examination in the present study. In each proposition, organisational commitment and job satisfaction are proposed as intervening variables linked in a linear relationship to both the predictor (antecedents) variables and the outcome (intentions to leave). 
1. The higher the rank, the higher the organisational commitment, the lower the intentions to leave.

2. The greater the length of service, the higher the organisational commitment, the lower the intentions to leave.

3. The greater the environmental pull, the lower the organisational commitment, the higher the intentions to leave.

4. The higher the rank, the higher the job satisfaction, the low $z r$ the intentions to leave.

5. The greater the length of service, the higher the job satisfaction, the lower the intentions to leave.

6. The greater the environmental pull, the lower the job satisfaction, the higher the intentions to leave.

7. The larger the organisation, the lower the organisational commitment, the higher the intentions to leave.

8. The larger the organisation, the lower the job satisfaction, the higher the intentions to leave.

9. Turnover intentions will be least likely when organisational commitment and job satisfaction are high.

10. Turnover intentions will be most likely when organisational commitment and job satisfaction are low.

11. Turnover intentions will fall between these two extremes when organisational commitment is high and job satisfaction is low or when organisational commitment is low and job satisfaction is high.

This chapter has outlined the theoretical framework of organisational commitment and job satisfaction and the research propositions which will be examined. The following chapter will discuss the particular research methodology utilised to test these propositions. 
Appendix 1

\section{Summary of Research Findings ${ }^{1}$}

\section{Variable}

Age

Education

Gender

Tenure

Need to Achieve

Strong Work Ethic

Role Conflict

Role Stress

Vested Financial Interests

Organisational Dependability

Feelings of personal importance

Performance

Absenteeism

Tardiness

Turnover

\section{Relationship to commitment}

Positive

Negative, the more educated, the more one is committed to a profession

Women are more committed than men because they have more obstacles to overcome

Positive

Positive

Positive

Negative

Negative

Positive

Positive

Positive

No rorsistent relationship

$\checkmark$, rirec: relationship

Negitivf.

Negizis: is s ixcame more so over time

1 Steers, Richard M., Mowday, Richard T. and Ponter, Lyman W. Emplovee Commitment to Organisations: A Conceptual Review. Technical Report No. 7. Office of Naval Research, Arlington, VA. 1981. 


\section{CRAPTER 3}

\section{METHODOLOGY}

\subsection{Introduction}

This chapter provides a discussion of the methodology utilised to research organisational commitment and job satisfaction within the Canadian Armed Forces with particular respect to the Navy.

The present study was designed to investigate the research questions:

(1) What is the level of organisational commitment and job satisfaction within the naval element of the Canadian Armed Forces? and,

(2) Do these factors contribute to voluntary intentions to leave?

The primary purpose of the study was to develop and test a model of turnover intentions based on current research. It is deemed to be exploratory research. As a consequence, the results of the study are not intended to generalise either to all personnel within Maritime Command or to all members of the Canadian Forces. It was intended to serve as a basis for further in-depth study and analysis. 
The design of the study was an ex post facto one which tested the major premise that selected antecedent variables, through the intervening variables of organisational commitment and job satisfaction, influenced the intentions to leave the Navy. The direct survey method was used for data collection.

\section{2 - Description of the Population}

The population used in this study was composed of personnel employed at the two training schools of Maritime Command located on Canada's east coast at Halifax, Nova Scotia and on Canada's west coast at Victoria (Esquimalt), British Columbia. The mandate of the Canadian Forces Fleet Schools (CFFSs), under the authority of the Commander, Maritime Command, is to conduct basic and advarced level naval training for regular and reserve members. Their organisations each consist of a Commandant; Deputy Commandant; an administrative and support unit which includes standards and evaluation; and a number of training divisions within which specialised training is conducted. These divisions include: combat, damage control, engineering and seamanship. Canadian Forces Fleet School (CFFS) Halifax also has the added responsibility of computer systems engineering training. Together the Fleet Schools train approximately 20,000 personnel each year. 


\subsection{Survey Sample}

The survey sample was drawn from the permanent directing (teaching) staff of the two Fleet Schools. The recruits undergoing training, at the time of the survey, were not included in the study. The staff population at CFFS Halifax is approximately 588 and at CFFS Esquimalt it is approximately 237 personnel

(Table 1). The staff at each school consists of all ranks from Ordinary Seaman to

Commander. Because of its larger size, CFFS Halifax is commanded by a

Captain (N). (Table 1 Source: DND DPIS Y90-12006 December 1990)

Table 1

CFFSs Halifax and Esquimalt Population and Sample Distribution by Rank

Rank

Ordinary Seaman

Able Seaman

Leading Seaman

Master Seaman

Petty Officer 2

Petty Officer 1

Chief Petty Officer 2

Chief Petty Officer 1

ASSub Lieutenant

Sub Lieutenant

Lieutenant

Lieutenant Commander

Commander

Captain (Navy)

Totals
CFFS Halifax

(East)

Sample Population
CFFS Esquimalt

(West)

Sample Population

$\begin{array}{rrrr}3 & 4 & 0 & 4 \\ 1 & 1 & 1 & 2 \\ 5 & 20 & 3 & 16 \\ 19 & 82 & 20 & 40 \\ 35 & 176 & 27 & 63 \\ 24 & 125 & 18 & 53 \\ 11 & 58 & 13 & 30 \\ 3 & 17 & 2 & 5 \\ 0 & 1 & 0 & 1 \\ 2 & 6 & 1 & 1 \\ 17 & 72 & 8 & 17 \\ 5 & 21 & 3 & 4 \\ 1 & 5 & 1 & 1 \\ 1 & 1 & 0 & 0\end{array}$

127

588

97

237 
Authorities dictated the size of the sample in that the prerequisite was to cause as little disruption to the training schedule and directing staff as possible. Consequently, 150 sample surveys were distributed at CFFS Halifax and 100 surveys were given to CFFS Esquimalt. The questionnaires were distributed within each school in proportion to the number of staff within each division. Thus, a stratified random sampling technique was used. For example, the two largest divisions at CFFS Halifax, combat and computer systems engineering, each received 45 questionnaires. The smallest, damage control division, received 9 questionnaires. A similar distribution took place at CFFS Esquimalt. Within each division, questionnaires were randomly distributed to staff that were present. Personnel away on temporary duty or leave, on the day the questionnaires were administered, were not sampled. This poteatial bias in sampling procedure was not controlled and, as a consequence, true random sampling was not possible.

One hundred and tweaty-seven of one hundred and fifty (84.7\%) from CFFS Halifax responded to the questionnaire while 97 out of one hundred (97\%) responded at CFFS Esquimalt. Respondents were from all rank levels within the total populations (Tables $2 \mathrm{~A} / \mathrm{B}$ and $3 \mathrm{~A} / \mathrm{B}$ ). Overall response rate was $89.6 \%$. An examination of non-respondents uid not indicate any evidence of response bias. 
Table 2A

Distribution of Respondents, by Rank

CFFS Halifax

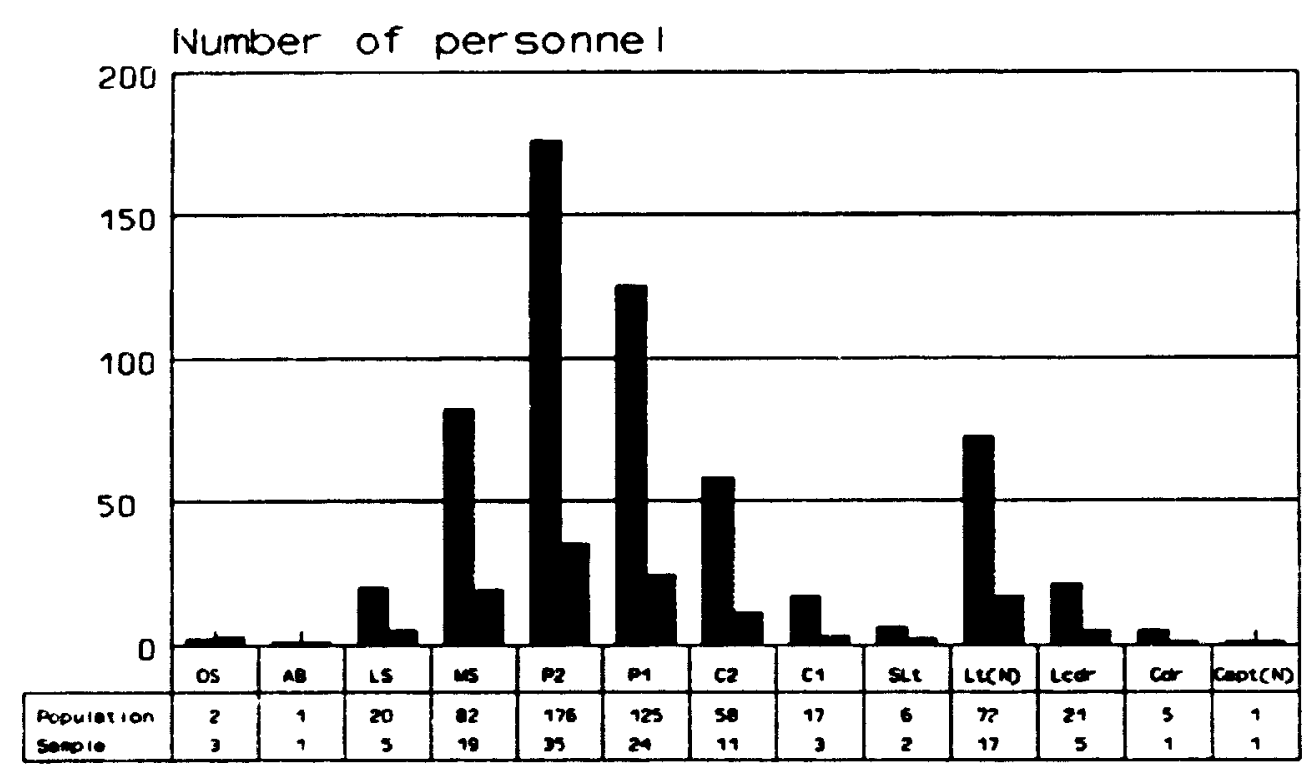

Rank

Source Department of Notlonal Defence

DPIS r9012006 Decemoer 1990 
Table 2B

Distribution of Respondents, by Rank

(\% of the total population)

CFFS Halifax

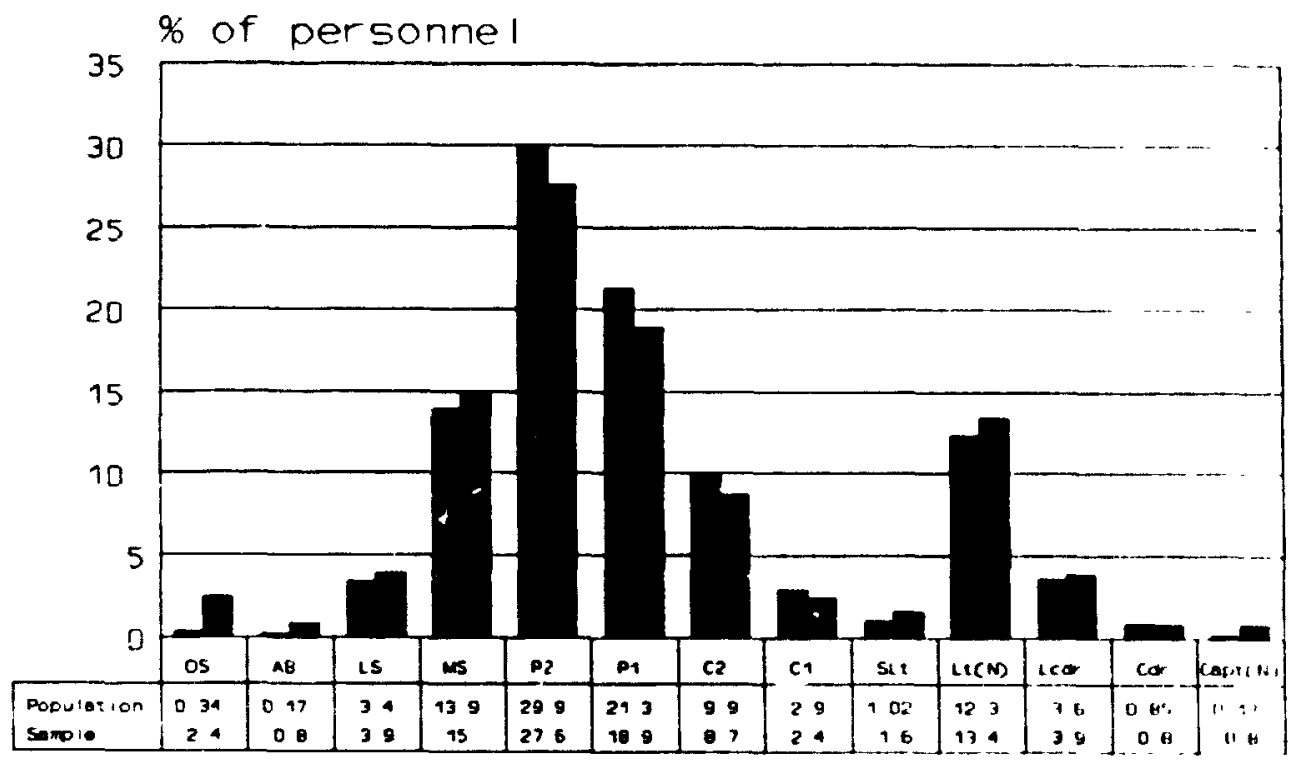

Fiarik

Papuletion Samite

Source Department of National Defence

DPIS Y9012006 December 1990 
Table 3A

Distribution of Respondents, by Rank

CFFS Esquimalt

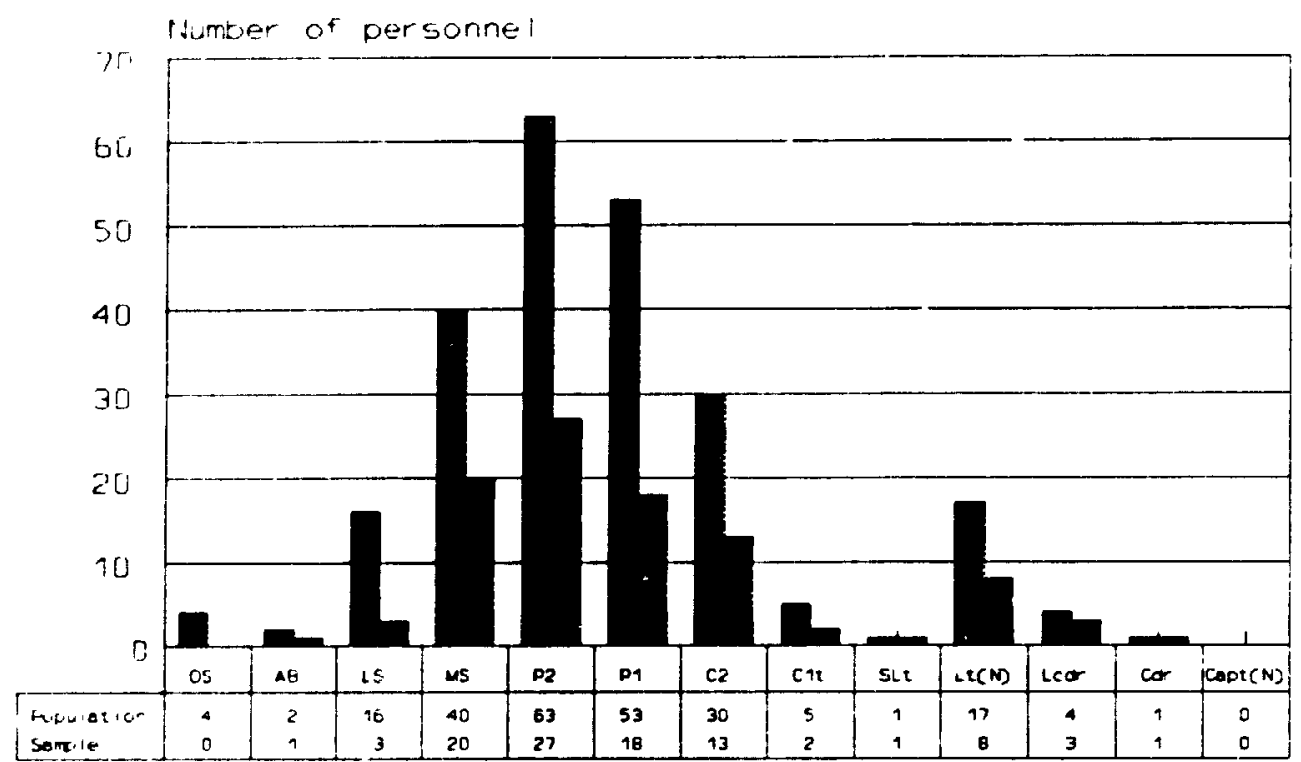

Fiank

Dooviation

sanole

Source Department of National defence

[PI: Y90 1200E Cecember 1990 
Table 3B

Distribution of Respondents, by Rank

(\% of total population)

CFFS Esquimalt

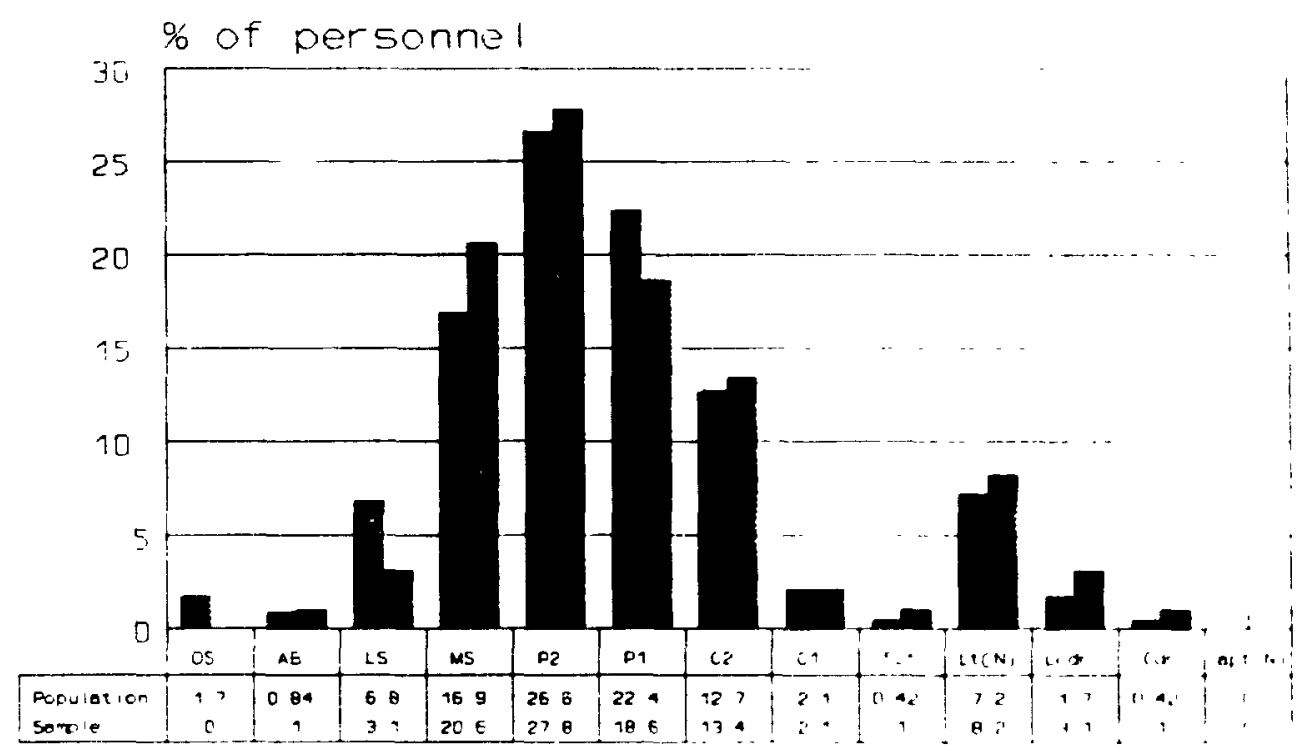

Fark

Daoularion smorite

Sirce Lepartment o Hat ional Defence

DD.S 49272005 Dezemoer 1990

Chi-square analysis was used to determine the representativeness of each of the samples from CFFS Halifax and Esquimalt to the total population of each of the training schools. Chi-square values were 19.158, $\mathrm{p}=.159, \mathrm{df}=14$ and 19.310, $\mathrm{p}=.153, \mathrm{df}=14$ for CFFSs Halifax and Esquimalt, respectively. Results indicated that no significant difference existed between the samples and the total population. 


\section{4 - Survey Questionnaire}

The survey instrument consisted of a 28 page anonymous (names and social insurance numbers were optional) questionnaire administered locally. The questionnaire is included at Annex A. Not all of the information collected on the questionnaires was analyzed. The answers to a total of 139 questions were analyzed including 15 relating to biographical information. The questionnaire was pretested on a small sample of military members and their comments were incorporated into the final questionnaire. The questionnaire was approved for use by the Deputy Chief of Staff Personnel and Training, Maritime Command, Halifax and administered under the auspices of the Commander, Maritime Command.

To increase the response rate, the questionnaires were distributed personally to each division by the respective Administration staff at each school and respondents were given 2 to 3 days to return them. A follow-up discussion session was undertaken by the researcher with voluntary personnel at CFFS Esquima' Time and work schedule did not permit discussion at CFFS Halifax. The discussion session provided a forum to provide comments on the survey and its contents, as well as other matters pertaining to naval issues in direct response to the questionnaire. 
The design and content of the questionnaire were based on a review of the theory and previous research on organisational commitment and job satisfaction. The questionnaire consisted of questions related to organisational commitment, job satisfaction, leave intentions, environmental pull and relevant biographical data.

\section{$\underline{3.5}$ - Variables}

A total of 4 independent variables was used. Intercorrelations of these variables indicated that all were independent measures with little relationship among them. The independent variables were:

(1) rank - 15 military rank categories were clustered into 3 rank categories: (a) junior non commissioned member (Junior NCM);

(b) senior non commissioned member (Senior NCM); and

(c) officers.

(2) service - Defined as the number of completed years served in the regular force. This variable was clustered into 3 categories which followed approximately logical career stages within the military: (a) 1.10 years; (b) $11-20$ years; and (c) 21 or more years. 
(3) organisational size - This variable took into account the relative size difference, in terms of the number of permanent staff on the establishment, between the two Fleet Schools. CFFS Halifax is approximately twice as large as CFFS Esquimalt.

(4) environmental pull (perceived alternatives) - Defined on a one item, 5 point Likert scale which asked "What are the chances that you can find a better alternative to your current employment outside the Navy?" This item was reverse coded so that a high score indicated that chances were unlikely to find other employment.

Two major intervening variables of organisational commitment and job satisfaction were measured on the following scales:

(5) organisational commitment - Measured by the Organisation Commitment Questionnaire (OCQ) developed by Mowday, Steers and Porter (1979). This is a 15 - item questionnaire based on a 7 point Likert scale rated from (1) strongly disagree to (7) strongly agree. The scale was originally administeref to 2500 employees in a variety of jobs and found to have an internal consistency measure based on an alpha of $r=.82$ to .93 . The convergent validity of the OCQ and the Job Descriptive Index (JDI) ranged from .01 to .68 
with a median correlation of .41 . Predictive validities for organisational commitment and turnover ranged from .19 to .43 . Organisational commitment was found to be better predictor of turnover than any facet of the JDI. Discriminant validity studies also suggested that: "the relationship found between commitment and satisfaction $(r=.52)$ were not so high as to lead one to conclude they were measuring the same thing" (Steers and Porter 1977:243).

This present study used a 5 point Likert scale (ranging from (1) strongly disagree to (5) strongly agree) rather than 7 point scale in order to provide for more discrimination among the categories. A "don't know" category was added but was not included in the data analysis.

(6) military commitment - Measured on the Military Ethos Scale (MES) developed by Cotton (1980). This scale is based on Moskos' institutional - occupational continuum. It consists of 6 items rated on a 5 point Likert scale ranging from (1) strongly agree to (5) strongly disagree. Range of measures is from 6 to 30 with a theoretical mean of 18. Summed scale values below 14 indicate low levels of commitment (defined as occupational commitment); those above 23 indicate high levels of commitment (defined as institutional commitment); and values between 15 and 22 indicate moderate 
levels of commitment (defined as ambivalent commitment). The internal consistency of the MES based on alpha was .78. A comparison of means among various groups suggests discriminant validity (Cotton 1980).

(7) forced choice - This measure was designed to indicate the degree of being forced to remain in the Navy for reasons other than commitment to the organisation. Respondents indicated on a 5 point Likert scale answers to the question: "I am remaining in the Navy only because I have other considerations (too close to pension to leave now, financial obligations, family responsibilities, job security etc.)". Scales ranged from (1) strongly disagree to (5) strongly agree. A Jon't know" category was included. This item was reverse coded so that a high score indicated that respondents were remaining in the Navy because they wanted to not because they had to. The assumption being that this was a positive commitment.

(8) job satisfaction - Measured on the six scales of the Job Descriptive Index (JDI) developed by Smith, Kendall and Hulin (1975). This index measures overall job satisfaction, as well as, satisfaction towards work, pay, promotion, supervision and fellow workers. Internal consistency measures yielded reliability estimates of .79 . 
Correlations between each of the scales ranged from .25 to .45 . Normative measures were found for $\mathbf{2 0 0 0}$ male and $\mathbf{6 0 0}$ female workers. On the basis of validation studies, Smith et al concluded that the scales of the JDI represent discriminate areas of satisfaction.

There was one measure of the dependent variable:

(9) leave intentions - Measured on a one item, 5 point Likert scale ranging from (1) extremely unlikely to (5) extremely likely and included a "don't know" category. This item was reverse coded so that a low score ind,cated a likelihood of having intentions to leave the organisation.

\section{6 - Data Analysis}

Missing data were deleted from all analysis with the exception of the organisational commitment scale (OCQ). Here the median for those missing values was used to make them comparable with those scales with full responses. Scales with more than a $10 \%$ missing value rate were not considered in the analysis. This occurred on only one occasion and it was not considered instrumental in the interpretation of the results. 
66

The sample size was predetermined. In using a stratified sample design, the questionnaires were distributed randomly within each division of the Fleet School. When the rank distributions were examined, the sample distributions followed approximately those of each of the populations at CFFSs Halifax and Esquimalt. (Tables $2 \mathrm{~A} / \mathrm{B}$ and $3 \mathrm{~A} / \mathrm{B}$ refer).

It was assumed, for the purposes of this study, that the data from Likert scale measures were interval scales. Consequently, the intervals between each of the Likert response items, scaled from 1 to 5 , were considered to be equal intervals, thus allowing for parametric analysis.

Frequencies and means for all relevant variables were used to complete preliminary descriptive analysis of the data. More in-depth analysis was undertaken using the Statistical Package for the Social Sciences version 3.1 (1988). Intercorrelations of all the variables indicated that variables were not highly correlated with one another. Analysis of variance and stepwise multiple regression techniques were first used to determine significant interaction and main treatment effects. Aptitude by treatment interaction (ATI) was then utilised to determine the significance of the interactions among the 4 independent, 2 global intervening and one dependent variable. Lastly, path analysis was used to determine the extent of the direct and indirect effects of significant predictor variables on the criterion measure, intentions to leave. 


\section{7 - Demographic Description of the Sample}

The average age of the sample was 35.1 years; the mode was 32 years. Average length of service in the Navy was 16.3 years with most respondents having 9 years service. Ninety - seven point three percent of the sample were males, only 5 females were included. On average, members had spent 17.2 months employed at the Fleet Schools with most serving 2 years. When asked to rate the importance of several factors in order of priority, over one third of the sample (37.1\%) rated family as their first consideration (most important); followed by a career in the Navy; their present position; and obtaining a career outside the Navy as the least important.

Rank, service and perceived alternatives were divided into three categories (Table 4). 
Table 4

Categories of Independent Variables

$\begin{array}{llll} & \text { Category } 1 & \text { Category } 2 & \text { Category } 3 \\ \text { Rank } & \begin{array}{l}\text { Junior NCM } \\ 52(23.2 \%)\end{array} & \begin{array}{l}\text { Senior NCM } \\ 133(59.4 \%)\end{array} & \begin{array}{l}\text { Officer } \\ 39(17.4 \%)\end{array} \\ \text { Service } & 1-10 \text { years } & 11-20 \text { years } & 23 \text { or more } \\ & 58(25.9 \%) & 98(43.8 \%) & 68(30.4 \%) \\ \text { Perceived } & \text { Likely } & \text { Undecided } & \text { Unlikely } \\ \text { Alternatives } & 87(38.8 \%) & 27(12.2 \%) & 94(42.0 \%)\end{array}$

Note: a. NCM $=$ non-aummissioned member

b. Source: Oakes Survey 1991

The following chapter provides comprehensive descriptive inferential analysis of the data using a variety of statistical techniques. 


\section{CHAPTER 4}

\section{ANALYSIS}

\subsection{Introduction}

This chapter provides the analysis of data collected from primary researcli.

Research was designed to test the model of turnover behaviour discussed

previously in Chapter 2 The model consisted of four independent predictors:

rank, service (tenure), environmental pull (perceived alternatives) and

organisational size (geographical location); three global intervening variables

measuring job satisfaction and organisational commitment; and one criterion

measure, the intention to leave the Navy. Fourteen variables were used to

evaluate the model (Table 5).

\section{Table 5}

Variables in the Turnover Intentions Model

Variable

Abbreviations

Variable

Measure Score

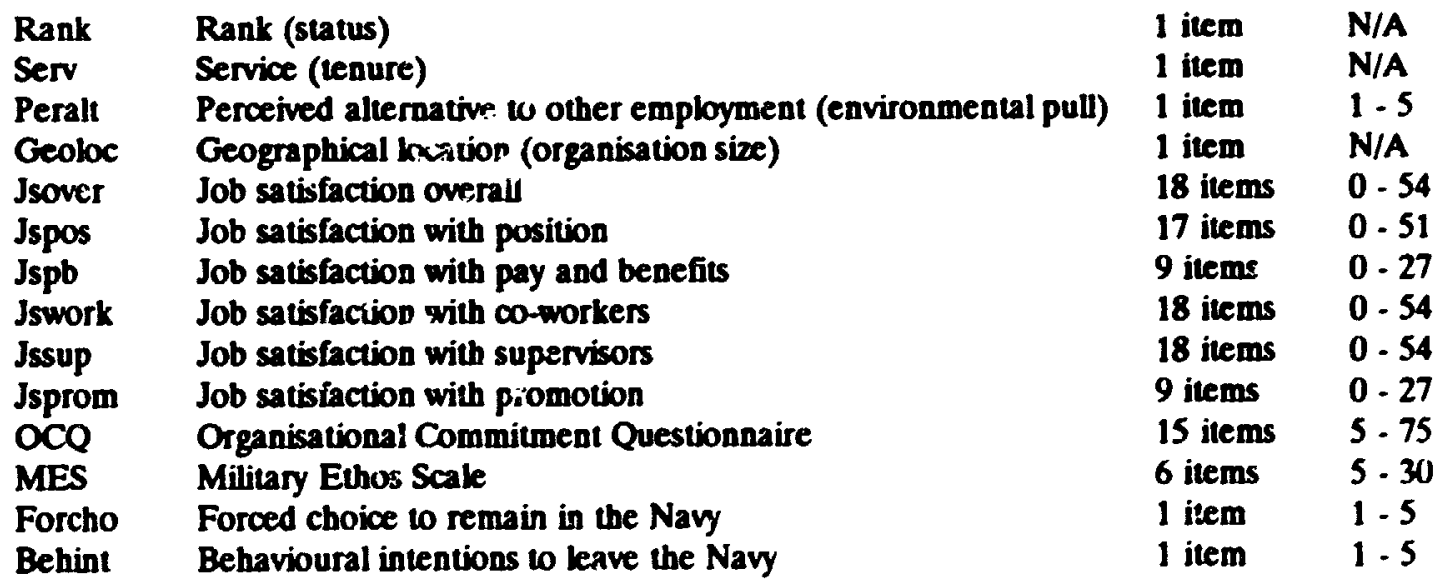


70

An intercorrelation matrix for the above variables was determined. The intercorrelations suggest that there was little collinearity among the variables, that they are independent and are not measures of the same characteristic (Tables 6 and 7).

\section{Table 6}

Correlations between Independent and Dependent Variables

$\begin{array}{lccc} & \text { Service } & \text { Peralt } & \text { Behint } \\ \text { Rank } & .0466 & .1800 & -.1768 \\ \text { Service } & & .1769 & -.2352 \\ \text { Peralt } & & & .2403\end{array}$

Table 7

Correlations between intervening and dependent variables

$\begin{array}{lllllll} & \text { Jsover } & \text { Jspos } & \text { Jsprom } & \text { Jspb } & \text { Jswork } & \text { Jssup } \\ \text { Behint } & .3238 & .1474 & .2608 & .1331 & .0958 & .0927 \\ \text { Jsover } & & .4388 & .3246 & .3170 & .4319 & .3332 \\ \text { Jspos } & & & .3128 & .2319 & .3684 & .4161 \\ \text { Jsprom } & & & & .2538 & .2361 & .2084 \\ \text { Jspb } & & & & & .2601 & .1900 \\ \text { Jswork } & & & & & & .3896\end{array}$

$\begin{array}{lccc} & \text { OCQ } & \text { MES Tot } & \text { Forcho } \\ \text { Behint } & .3852 & .1333 & .2723 \\ \text { OCQ } & & .4537 & .4058 \\ \text { MES Tot } & & & .2329\end{array}$

Source: Oakes Survey 1991. 
Overall only some support was found for the interaction of job satisfaction and organisational commitment as intervening variables between several of the antecedents (predictor measures) and the outcome (turnover intentions). However, within the model there were found significant effects between (1) the predictor measures and those of job satisfaction and organisational commitment; and (2) organisational commitment and job satisfaction with intentions to leave.

\subsection{Descriptive Analysis}

Crosstabulations were performed on all variables using various combinations of predictor, criterion and intervening measures. The six scales of the Job Descriptive Index were analyzed separately. Relationships among the independent variables and intentions to leave were examined (Tables 8-11 Appendix 2). It was found that Officers were more likely to have intentions to leave the Navy than Junior or Senior NCMs (non-commissioned members). This is contrary to that predicted by the model which suggested that as rank increased, intentions to leave would decline. A similar result was found for service or tenure. As tenure increased, the likelihood of leaving the Navy also increased. Those military members with more than 20 years of service were the most likely to have intentions leave the Navy. A predictable result was found for the availability of perceived alternatives. The more likely it was that members had alternative employment opportunities, the more likely they would have intentions to leave the 
Navy. Geographical location or organisational size appeared to have had little impact on intentions to leave the organisation.

Examination of crosstabulation tables for: (1) independent on intervening measures and (2) intervening on dependent measures indicated the following:

a. rank - Little or no relationship was found between rank and all six scales of the Job Descriptive Index (JDI). Officers were no more satislied than the other ranks. In addition, JDI measures had no effect as a global intervening variable between the predictor and criterion measures. The intentions to leave the Navy increased as rank increased, regardless of the level of job satisfaction.

The relationship between rank and the three organisational commitment measures: Organisation Commitment Questionraire (OCQ); Military Ethos Scale (MES); and Forced Choice to remain in the Navy (Forcho), was not definitive in any direction. The highest percentage of cases in all rank categories was found when military ethos (MES) and OCQ was neither low nor high. The predominance of the neutral category on the MES measure irdicated that members were neither strongly institutional nor vocational in their attitude iowards the Navy. Like the JDI measures, none of the organisational 
commitment measures affected the linkage between the independent and dependent variables.

b. service - Although no systematic relationship was found between service length and JDI measures, the 11-20 year tenure was consistently shown to he the period most affected by job satisfaction. This was particularly true for job satisfaction with position; with promotion and with supervisors. For the remaining JDI scales (overall, pay and benefits and co-workers), as service length increased, so too did satisfaction in these areas. The predicted relationship between job satisfaction measures and intentions to leave, was found for all scales with the exception of job satisfaction with pay and benefits. That is, as satisfaction increased, the likelihood of having intentions to leave decreased. As was found with rank, the job satisfaction scales did not change (intervene) the initial relationship between service length and intentions to leave.

A positive relationship between service, and OCQ and MES, was found. These measures increased as length of service increased. The 11-20 year period was most affected by Forcho. Those "locked-in" by the organisation were less likely than those with either more (over 20 years) or less service (under 11 years) to say that they were forced to 
stay. Organisational commitment measures did not alter the original relationship between the predictor and criterion measures in a way that had been predicted by the turnover model. That is, as service length increased, intentions to leave increased regardless of level of commitment. The remaining JDI scales (pay and benefits, co-workers and supervisors) showed an inconsistent relationship with the criterion measure (intentions to leave).

c. perceived alternatives (peralt) - In general, as the perceived alternatives to other employment became more unlikely, (environmental pull decreased) job satisfaction increased and intentions to leave decreased, as the model predicted. The same was true for all organisational commitment measures. Neither these, nor the JDI measures intervened to change the relationship between perceived alternatives (peralt) and intentions to leave. Thus, that for this predictor measure, (like the others), job satisfaction and organisation commitment variables had no intervening effect.

d. geographical location/organisational size - This variable had little or no effect on JDI or organisational comnitment measures. There was no difference between the East coast and West ccast units on any of the 
research variables. Therefore no further analysis was deemed warranted for this variable.

e. job satisfaction - Job satisfaction overall; with position; and with promotion, were found to be negatively related to intentions to leave. In all cases, as these measures increased, intentions to leave decreased. The remaining JDI scales (pay and benefits, co-workers and supervisors) showed an inconsistent relationship to the criterion measure.

f. organisational commitment - Ali measures had a consistent and predictable relationship with leave intentions. As OCQ and MES increased, the likelihood of having intentions to leave the Navy declined. Those who responded that they were remaining in the Navy because they had to (Forcho) were more likely to have intentions to leave.

Analysis of variance, aptitude by treatment interaction effects, multiple regression and path analysis techniques were used to complete further in-depth analysis of the data. The results of this analysis will be examined and discussed. 


\section{3 - Inferential Analysis}

Results of confirmatory analysis indicated some support for the turnuver intentions model on two of the predictor variables (service and perceived alternatives); three of the job satisfaction measures (promotion, position and overall) and three of the organisational commitment measures (OCQ, MES and Forcho). Propositions that job satisfaction and organisation commitment would contribute positively (from an organisational view) to leave intentions (that is: if high levels of these constructs exist, members would be most unlikely to have intentions to leave) were supported. The propositions with regard to rank were not supported, in that rank was found not to be negatively correlated, but rather positively correlated with leave intentions. Officers were more likely to indicate intentions to leave than Junior NCMs, contrary to the proposition that they would be more likely to have intentions to stay. The relationship between service and leave intentions, as proposed, was supported only for the 11-20 year category. The proposition that as perceived alternatives became less likely, so too did the intentions to leave the organisation was supported.

Job satisfaction and organisational commitment measures did not act as intervening variables in the way the turnover intentions model had predicted. Though significant interactions were found, they did not alter the primary 
relationship between the predictor and criterion measures, as it had heen proposed.

\subsection{1 - Analysis of Variance (ANOVA)}

In order for the ANOVA technique to be used with continuous variables, each of the job satisfaction scales and organisational commitment measures were categorised into three groups on the basis of their distributions using percentiles. The "building block" method to the model was used in this analysis. That is, the effects of each of the predictor variables (with the exception of geographical location) on the criterion and intervening measures; and the effects of the intervening measures on the criterion variable, were examined. Lastly, the turnover intentions model, itself, was examined in relation to all of these variables. Graphical representations for the significant relationships are found in Figures 3-14 Appendix 3. The geographical location variable was deleted from further analysis because it did not have any influence on the intervening or dependent variables and was not considered instrumental to the analysis. Results of the analysis was as follows:

(1) Rank - Analysis did not support the proposition that turnover intentions would decrease as rank increased. Rank, in fact, was shown to be positively related to leave intentions. Officers were more likely to leave 
the Navy than Junior or Senior NCMs $(M=2.68$ versus $M=3.30$ and 3.71, respectively). Officers were found to be significantly different from the other two categories.

Analysis of variance techniques used on this predictor measure and the intervening variables, found that rank was not significantly related to any of the job satisfaction measures. However, it was related to two of the organisational commitment scales (OCQ and MES). An F value of 3.323, $p=.038$ was found for the OCQ scale. Senior NCMs were more organisationally committed than officers or Junior NCMs $(M=51.16$ versus $M=48.81$ and 50.44 , respectively). Although it was expected that Junior NCMs would be less organisationally committed, the relationship did not support the proposition that Officers were predicted to be the most committed. On the MES measure $(F=11.351, p=.000)$, however, Officers were found to be more committed to the organisation $(M=20.615)$ than Junior or Senior NCMs $(M=17.333$ and 20.269, respectively), as it had been proposed in the model. Thus, for this particular measure, as rank increased, organisational commitment (MES) increased. The relationship between rank and Forcho was not significant. 
(2) Service - Contrary to what the model predicted, those longest serving members (over 20 years) were the most likely to have intentions to leave $(M=2.73)$, followed by those with the least amount of service (1-10 years, $M=3.51)$. This appeared to suggest a curvilinear rather thar. a simple linear relationship between service length and leave intentions. Naval members of the sample who were least likely to have intentions to leave the organisation were those who had 11-20 years of service $(M=3.54)$. As noted in the preliminary analysis, this period appears to be the most "critical" in terms of staying in or leaving the Navy.

The relationships between this predictor variable and the intervening measures, indicated that service was significantly related to only one of the job satisfaction variables - promotion ( $F$ value of $6.321, p=.002)$. One-way analysis found that job satisfaction witt. promotion was inversely related to service length. Those indicating the most dissatisfaction with promotion were those having the longest service $(M=11.35)$. The most satisfied members $(M=16.38)$ had the least amount of time in the Navy (1-10 years). Those having 20 or more years of service were found to be significantly different than the other two groups on this variable. 
80

Service was also significantly related to two of the organisation commitment measures (OCQ and MES). An F value of $4.886, p=.008$ was found for the OCQ variable. Analysis confirmed the proposition that as service length increased, organisational commitment increased. Those having $\mathbf{2 0}$ or more years of service were the most committed $(M=51.87)$, on $O C Q$, while those having 1-10 years of service were the least committed $(M=48.78)$. Members having 11-20 years of service had a mean commitment score of 50.54. A similar positive relationship was found for the MES measure. The group having 1-10 years service were less committed ( $M=18.50)$ than the longest serving group $(M=21.51)$. Service length had no effect on Forcho.

(3) Perceived alternatives (peralt) - Environmental pull (peralt) was significantly $\mathrm{r}$ ?lated to leave intentions $(\mathrm{F}=5.355, \mathrm{p}=.005)$ and supported the model prediction that as environmental pull became more unlikely (decreased), intentions to leave also became more unlikely. Those who indicated that they were likely to find alternative employment wer: most likely to have intentions to leave $(M=2.85)$. Conversely, those who indicated that they were unlikely to find other employment were least likely to have intentions to leave $(M=3.55)$.

Analysis indicated that this predictor variable was significantly related to two of the job satisfaction measures: overall and position $(F=6.360, p=.002$ and 
$F=3.321, p=.038$, respectively). Some support for the proposition that the greater the environmental pull (Peralt), the lower the job satisfaction, was found for this measure. Those who indicated that they were likely to find alternative employment had the lowest job satisfaction overall $(M=41.71)$. However, those having the highest measure of overall satisfaction $(M=46.48)$ were found in the undecided category. Those indicating that they were unlikely to find alternative employment (environmental pull was low) had a mean satisfaction score of 45.67).

A more systematic relationship was found for job satisfaction with position measure. In this case, the proposition predicted by the model was confirmed. As environmental pull (peralt) became more unlikely (decreased), job satisfaction with position increased $(M=29.64$ versus $M=33.32)$.

Peralt was found to have a significant relationship with only one of the organisational commitment measures - OCQ $(F=3.758, p=.025)$. This measure supported the proposition that as environmental pull increased, organisation commitment declined. Those who indirated that they were likely to find alternative employment were less organisationally committed $(M=49.18)$ than those who were unlikely to find other employment $(M=51.42)$.

Interaction effects were examined between the predictor and intervening variables in various combinations of independent measures. The intervening 
measures here, were considered as dependent variables. Significant two-way predictor interactions were found for the following:

(1) rank and service with job satisfaction, position $(F=5.545, p=.001)$. Further analysis indicated that the interaction was most significant for Officers ( $F=4.74, p=.015$ ). Officers who had the longest service (over 20 years) were more satisfied with their employment position $(M=33.82)$ than those who had the least amount of service $(M=22.93)$ or those who had 11-20 years of service $(M=33.79)$. Those Officers who had 1-10 years were found to be significantly different from both the groups having longer service. In addition, for ali members having 1-10 years of service, Officers were less satisfied with their position $(M=22.93)$ than either Senior or Junior NCMs $(M=33.00$ and 34.66 , respectively).

(2) rank and service with job satisfaction, promotion $(F=4.786, p=.003)$. This interaction was particularly significant for Junior and Senior NCMs $(F=6.321, p=.002$ and $F=9.755, p=.000$, respectively). For both Junior and Senior NCMs, those who had the most time in the service were the least satisfied with their promotion opportunities $(M=11.35$ and 11.29). Those Junior and Senior NCMs most satisfied $(M=16.58$ and 24.00, rtspectively) had the least amount of service (1-10 years). 
Consequently, for these groups (Junior and Senior NCMs), service length and job satisfaction with promotion were inversely related. This relationship for Officers, however, was curvilinear. That is, those Officers who had 11-20 years in the Navy were the most satisfied with promotion $(M=18.41)$. Those who were the longest serving members (20 years or over) were the least satisfied with promotion $(M=11.60)$. For Junior and Senior NCMs, the longest serving members were significantly different from the other two groups each having served less time. For all members who had 1-10 years service, Officers were found to be the least satisfied with promotion $(M=12.00)$. Those most satisfied were Senior NCMs $(M=24.00)$. Thus, as rank increased, job sãtisfaction with promotion decreased.

No significant interactions were found for any of the independent variables with the organisational commitment measures.

Combinations of independent and intervening variables were examined to determine interaction effects on the criterion measure. Significant interactions between the following independent and intervening measures (in combination) on intentions to leave were found. These were:

(1) service and job satisfaction with position; 
(2) rar.k and job satisfaction with promotion; and

(3) rank and job satisfaction with position and overall.

Significant interactions were found between the following intervening measures and intentions to leave. These were:

(4) job satisfaction with promotion and $O C Q$;

(5) job satisfaction with promotion and MES.

Significant interactions were further analyzed using the Student - Newman Keuls test of .05 significance to determine which groups were significantly different.

(1) Service and job satisfaction with position:

When service and job satisfaction with position were examined, an $F$ value of $3.02, p=.019$ was found. This interaction, confirmed preliminary findings, in that, service was positively related to intentions to leave. Regardless of an increase in satisfaction, those longest serving members (over 20 years) were the most likely to have intentions to leave the Navy $(M=281)$. Those least likely to have intentions to leave were those who had the least amount of service - 1 to 10 years 
$(M=3.87)$. They, perhaps, had less time to become dissatisfied with their employment. It must be considered, however, that at least half of this period is the 'training stage'.

(2) Rank and job satisfaction with promotion

The interaction between rank and job satisfaction with promotion produced an $F$ value of $2.49, p=.044$. When the relationship was examined for simple effects, job satisfaction with promotion did not increase as rank increased. Officers were the most likely to have intentions to leave the Navy $(M=2.53)$ and Junior NCMs the least likely to have leave intentions $(M=3.91)$ regardless of satisfaction level. Officers were less satisfied with promotion than the other ranks $(M=12.2)$. Senior and Junior NCMs on this scale had mean satisfaction scores of 24.0 and 16.5 , respectively. However, for all rank levels, as satisfaction with promotion increased, the intentions to leave became more unlikely, as predicted in the turnover model.

(3) Rank, job satisfaction overall and with position Rank, job satisfaction with position and job satisfaction overall was the only significant three-way interaction found in the study $(F=2.869$, 


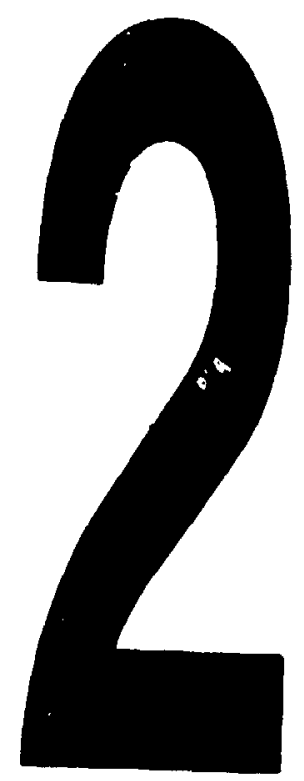

PM-1 31/2"X" PHOTOGRAPHIC MICROCOPY TARGET MBS 1010a ANSI/ISO "2 EOUIVALENT

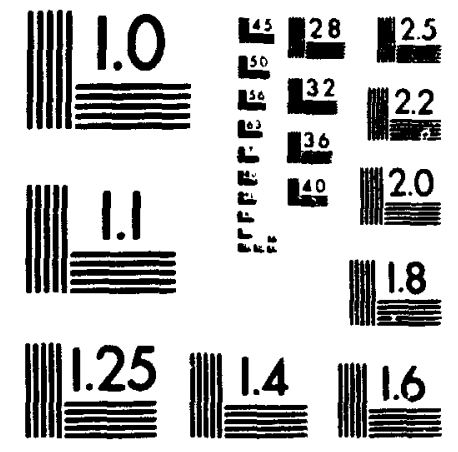


86

$\mathrm{p}=.011$ ). Analysis of simple effects indicated that the relationship between rank and job satisfaction overall contributed most to the significance of this interaction. Job satisfaction with position (Jspos) and rank, alone, in themselves, proved not to be significant. Rank categories contributing to the effect were Junior and Senior NCMs. For each of these groups, as satisfaction overall increased, the irtentions to leave declined. Those most satisfied, were those least likely to have intentions to leave $(M=4.58$ and 3.82$)$. Conversely, those who were least satisfied were those most likely to have intentions to leave $(M=3.35$ and 2.29). At the highest level of job satisfaction, Officers were most likely to have intentions to leave the Navy $(M=2.67)$ and Junior NCMs were least likely to have intentions to leave $(M=4.58)$. Consequently, even when Officers were highly satisfied overall, they were the most likely group to have intentions to leave the organisation.

(4) Job satisfaction with promotion and OCQ

Job satisfaction with promotion interacted significantly with $\mathrm{OCQ}$ $(F=3.662, p=.007)$. The highest and lowest categories of job satisfaction produced a consistent inverse relationship between organisational commitment and leave intentions. Those most 
committed to the organisation were the least likely to have intentions to leave $(M=3.77)$. Conversely, those who indicated a low commitment were most likely to have intentions to leave $(M=1.96)$. In addition, the highest and lowest categories of $\mathrm{OCQ}$ were significant. When $\mathrm{OCQ}$ was low, those least likely to have intentions to leave were only moderately satisfied with promotion $(M=2.91)$ and when OCQ was high, those least likely to have intentions to leave $(M=4.39)$ also had high job satisfaction. This suggests a positive relationship between job satisfaction with promotion and one measure of organisational commitment predicted by the model.

(5) Job satisfaction with promotion and MES significantly interacted. An $F$ value of $4.370, p=.002$ was found. Further analysis suggested that when job satisfaction with promotion was at its highest level, as organisational commitment increased, the intention to leave was the most unlikely $(M=4.39)$. Other levels of job satisfaction produced no significant differences among the groups for leave intentions. When MES was low, leave intentions were most likely $(M=2.60)$. Furthermore, when MES was high, those most unlikely to have leave intentions $(M=4.09)$ had the highest levels of job satisfaction. MES and Jsprom, therefore, had a direct positive relationship. 


\section{2 - Aptitude by Treatment Interactions}

To test for further interaction effects, each of the independent and intervening measures, found significant in previous analysis, were combined to create new 'typological' variables. These were then regressed onto the criterion variable. Those that were found to be significant were:

(1) Rank and job satisfaction with promotion. An $F$ value of $11.47, p=.000$ was found. The new variable created with this combination produced an $R$ square change of .023 for an overall $R$ square of .139 . Beta weights were: rank - .474; jsprom - .228; and rank $x$ jsprom .558 .

(2) Job satisfaction with promotion and MES. An $F$ value of $22.38, p=.000$ was found. The new variable created produced an overall $R$ square of .096 and a beta weight of .309 .

One final significant interaction found was:

(3) Rank and MES with an $F$ value of $6.12, p=.014$

The new variable created with this combination produced an $R$ square change of .026 for an overall $R$ square of .108 . Beta weights were: rank .523; MES .629; and rank x MES -1.02. 
In all cases, the interactions, produced with these combinations, contributed more to explaining the variance of the criterion variable (leave intentions) than the individual variables themselves.

\subsection{3 - Regression Analysis}

Stepwise multiple regression analysis was used to determine the best predictors of the dependent measure. The predictor and intervening variables were each used as an independent measure on leave intentions. Those variables which were nominally scaled were recoded into dummy variables. The curvilinear relationship between service length and intentions to leave was controlled using the logarithm $(\log 10)$. Rank, service and perceived alternatives (environmental pull) each predicted in some measure intentions to leave (Table 12). The regression equation for these variables was:

leave intentions $=4.245-.553($ rank $)-.177$ (logservice) +.379 (peralt)

Table 12

Regression Values for Predictor Variables on Criterion Measure

$\begin{array}{lcccc} & \text { R square } & \text { R square change } & \text { Standard error } & \text { Beta weights } \\ \text { peralt } & .049 & .049 & 1.45 & .239 \\ \text { logserv } & .109 & .059 & 1.41 & -.252 \\ \text { rank } & .129 & .020 & 1.39 & -.144\end{array}$


Although all measures were found significant, together the independent variables explained only $12.9 \%$ of the variance in leave intentions, with most of the variance (5.9\%) accounted for by service or tenure. The negative direction of both service and rank supported earlier analysi:, in that, as intentions to leave became more unlikely (increases), service and rank level declined. Thus, those with lower rank and less service were les: likely to have intentions to leave the Navy than those having longer service and higher rank.

Regression of the predictor variables on the measures of job satisfaction produced $R$ squares ranging from a low of $.021, p=.036$ (Jswork, Jssup and Jsph) to a high of $.069, p=.001$ (Jsprom). Service was found to be a significant predictor of Jsprom, OCQ and MES. This was supportive of the ANOVA analysis. Peralt predicted all six measures of job satisfaction and one measure of organisational commitment - OCQ. ANOVA found that Peralt was significantly related to only to Jsover and OCQ. Rank was not a predictor of any of the intervening variables. Other analysis had suggested a relationship to $O C Q$ and MES. None of the independent variables was a significant predictor of Forcho.

The relationships between the intervening measures of job satisfaction and organisational commitment on intentions to leave were also examined using regression analysis. The results indicated that only one of the six job satisfaction scales was found to be significantly related to leave intentions. This was job 
satisfaction with promotion. An $R$ square value of $.029, p=.000$ was found for this scale. Simple effects analysis confirmed the proposition predicted in the model that, as job satisfaction with promotion increased, intentions to leave the Navy became more unlikely. Those that indicated that they were unlikely to have intentions to leave the Navy, had the highest satisfaction level $(M=13.22)$. Those who indicated likely intentions to leave had the lowest satisfaction of $\mathrm{M}=11.12$. Those likely to have leave intentions were significantly different from those who were unlikely to have intentions to leave.

The regression equations indicated that $\mathbf{R}$ squares were moderately low for the promotion measure, predicting only $2.9 \%$ of the variance. Consequently, although analysis found a significant relationship between this job satisfaction measure on leave intentions, it, in fact, had little overall impact on the criterion variable.

Analysis indicated that one of the organisational commitment measures was significantly related to leave intentions. OCQ was found to have an $\mathrm{R}$ square value of $.149, p=.000$. Thus, $14.9 \%$ of the variance in the intentions to leave was explained by the OCQ organisationai commitment measure. Simple effects supported the proposition that as organisational commitment increased, intentions to leave became more unlikely. The least committed group was that most likely to have intentions to leave $(M=3.23)$, and those members most committed were the 
least likely to have leave intentions $(M=3.70)$. The regression equation and values (Table 13) for the significant intervening measures on leave intentions was:

leave intentions $=-1.67+.090(\mathrm{OCQ})+.029(\mathrm{Jsprom})$

\section{Table 13}

Regression Values for Significant Intervening Variables on Criterion Measure

$\begin{array}{lcccc} & \text { R square } & \text { R square change } & \text { Standard error } & \text { Beta weights } \\ \text { OCQ } & .149 & .149 & 1.347 & .345 \\ \text { Jsprom } & .179 & .029 & 1.344 & .174\end{array}$

The intervening variables explained $17.9 \%$ of the variance in intentions to leave.

When all independent and all intervening measures were regressed on to leave intentions, only four were found to be significant predictors of behavioural intentions: OCQ, logservice, peralt and rank (Table 14). The regression equation was as follows:

$$
\begin{aligned}
\text { leave intentions }= & -.279+.110(\text { OCQ })-2.39 \text { (logservice) } \\
& +.294 \text { (peralt) }-.629 \text { (rank). }
\end{aligned}
$$


Table 14

Regression Values for Significant Independent and Intervening Variables on Criterion Measure

$\begin{array}{lcccc} & \text { R square } & \mathrm{R} \text { square change } & \text { Standard error } & \text { Beta weights } \\ \text { OCQ } & .146 & .146 & 1.37 & .419 \\ \text { logservice } & .235 & .089 & 1.30 & -.343 \\ \text { peralt } & .278 & .043 & 1.27 & .186 \\ \text { rank } & .304 & .026 & 1.25 & -.164\end{array}$

Together these variables explained $30.4 \%$ of the variance in leave intentions with the organisational commitment (OCQ) variable contributing the most (14.6\%). Although one satisfaction measure was found initially to contribute to the predictor (Jsprom), when regressed in combination with the independent variables, it did not contribute significantly. Job satisfaction with promotion was found to contribute to the criterion only when it was used individually and not in combination with other intervening variables. Thus, none of the job satisfaction measures contributed to intentions to leave.

\subsection{4 - Path Analysis}

The empirical research undertaken in this study was designed, in part, to test a theoretical model of the causation of turnover intentions. Previous analysis had supported correlations among the variables studied; some interactions; some linkages between the predictor, intervening and criterion variables; and some 
curvilinear relationships. The concept of causation, however, remained unclear. Although violating several of the underlying assumptions of path analysis, that of linearity and causality, as well as, interval scaling, path analysis was completed on the basis that the model was initially proposed as a linear, causal one. Consequently, the determination of direct and indirect effects would be important in understanding the particular dynamics found in this particular study.

Because of the number of variables involved, a parsimonious approach was used. That is, only those variables which were found in previous analysis to contribute to the causal effect or had Beta weights of more than .1 (when rounded), were used. Thus, path analysis was completed on three independent variables (rank, service and perceived alternatives); three intervening variables (job satisfaction overall, with promotion and $\mathrm{OCQ}$ ) separately; and the criterion, leave intentions (Figures 15-17). In addition, the independent variables were assumed to be all exogenous variables. The results of this analysis are as follows. 


\section{Eiqure 15}

Path Analysis

Job Satisfaction Overall as an Intervening Variable

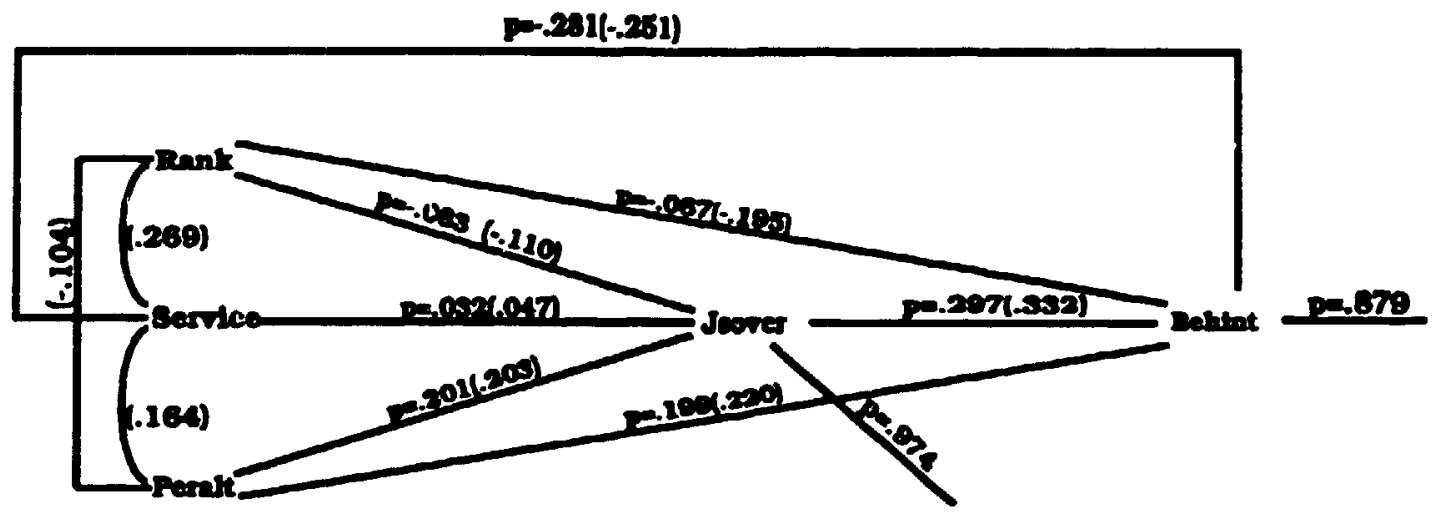

Jsover

DE U
Leave intentions

DE IE TE U

$\begin{array}{llll}-.067 & -.025 & -.092 & -.073\end{array}$

$\begin{array}{llll}-.281 & .009 & -.272 & .042\end{array}$

$\begin{array}{llll}.199 & .059 & .258 & .004\end{array}$

$\begin{array}{lrrrrrr}\text { Rank } & -.083 & .086 & -.067 & -.025 & -.092 & -.073 \\ \text { Service } & .032 & .033 & -.281 & .009 & -.272 & .042 \\ \text { Peralt } & .201 & .009 & .199 & .059 & .258 & .004 \\ \text { Jsover } & & & .297 & & & \end{array}$

Note: $\mathrm{DE}=$ direct effects $\mathrm{IE}=$ indirect effects $\mathrm{TE}=$ total effects $\mathrm{U}=$ unanalysed 
Eipure 16

Path Analysis

Job Satisfaction with Promotion as an Intervening Variable

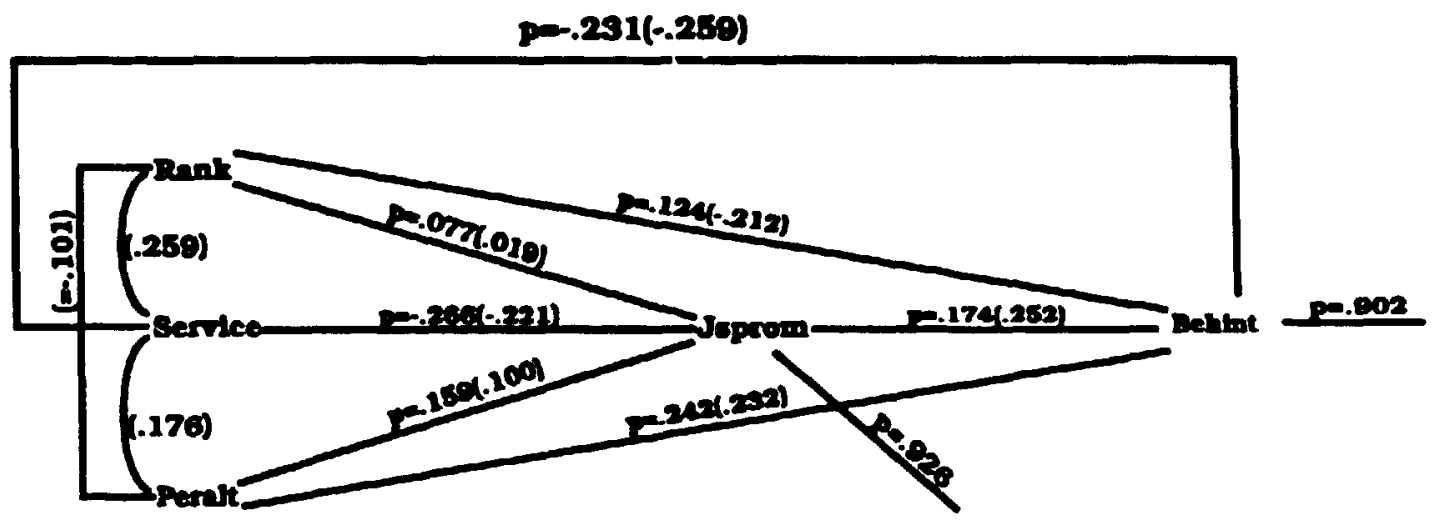

Jsprom

Leave intentions

$\begin{array}{lllll}\text { DE } & \mathrm{U} & \mathrm{DE} & \mathrm{IE} & \mathrm{TE}\end{array}$

$\begin{array}{lrrrrrr}\text { Rank } & .077 & -.069 & -.124 & .013 & -.111 & .071 \\ \text { Service } & -.266 & .028 & -.231 & -.046 & -.277 & .048 \\ \text { Peralt } & .159 & .008 & .242 & .028 & .272 & .016 \\ \text { Jsprom } & & & .174 & & & \end{array}$

Note: $\mathrm{DE}=$ direct effects $\mathrm{IE}=$ indirect effects $\mathrm{TE}=$ total effects $\mathrm{U}=$ unanalysed 
Eiqure 17

Path Analysis

Organisational Commitment (OCQ)

as an Intervening Variable

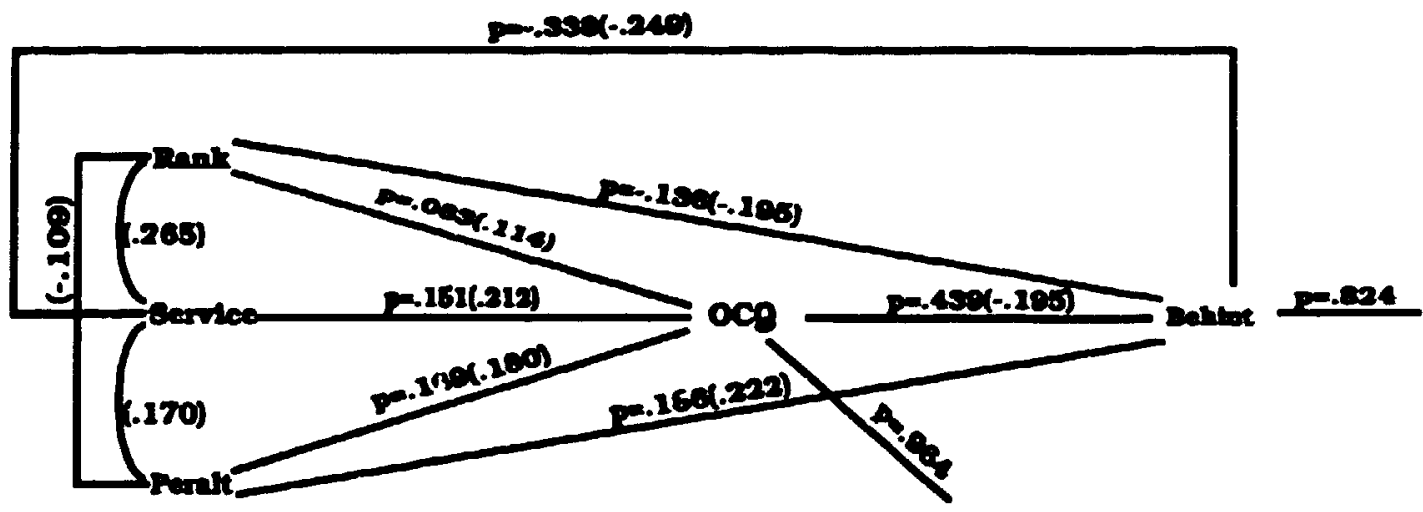

OCQ

Leave intentions

$\begin{array}{llllll}\text { DE } & \mathrm{U} & \mathrm{DE} & \mathrm{IE} & \mathrm{TE} & \mathrm{U}\end{array}$

$\begin{array}{lllllll}\text { Rank } & .083 & .04 & -.136 & .036 & -.100 & .107 \\ \text { Service } & .151 & .03 & .338 & .066 & -.272 & .052 \\ \text { Peralt } & .169 & -.01 & .186 & .074 & .260 & .041 \\ \text { OCQ } & & & .439 & & & \end{array}$

Note: $\mathrm{DE}=$ direct effects $\mathrm{IE}=$ indirect effects $\mathrm{TE}=$ total effects $\mathrm{U}=$ unanalysed

In all cases, among the independent measures, service had the greatest effect on intentions to leave followed by perceived alternatives. Rank had the least effect on the criterion variable. In addition, the direct effects of the criterion measure were larger than their indirect effects. This supports earlier analysis that the intervening variables did little to enhance the relationstip between the independent and dependent measures. This was particularly true for service, 
where its indirect effect on leave intentions, through job satisfaction overall, was almost zero (.009). In two instances, the intervening variables, Jsover and OCQ, had a larger direct effect on leave intentions than any of the predictor variables.

\subsection{Institutional Versus Occupational}

The Military Ethos Scale (MES) was used by Cotton (1980) to determine the range of attitudes members had toward the military organisation. First conceptualised by Moskos (1977), the institutional - occupational concepts represented two ends of a ccntinuum, where on the one hand the military organisation is seen as one which is "highly divergent from civilian society (institutional) and, on the other, to one highly convergent with civilian structures" (occupational) (Moskos 1986:377). Cotton (1980) found that senior Officers rated more highly on the military ethos scale. This suggested that they hau a predominately institutional (soldier), as opposed to, an occupational or employee conceptual view of the military. In the sample of naval personnel studied in this research, similar findings were discovered. Crosstabulations of rank category on the three levels of the MES (low, neutral and high) were found (Table 15). 
99

Table 15

\begin{tabular}{ccc}
\multicolumn{3}{c}{ Military Ethos Scale by Rank Category } \\
Low MES & Neutral MES & High MES \\
$<14$ & $15-22$ & $>23$
\end{tabular}

$\begin{array}{llll}\text { Junior NCM } & 60.0 \% & 23.7 \% & 11.3 \%\end{array}$

$\begin{array}{llll}\text { Senior NCM } & 40.0 \% & 59.0 \% & 66.0 \%\end{array}$

$\begin{array}{llll}\text { Officers } & 0.0 \% & 17.3 \% & 22.6 \%\end{array}$

Chi-squarc $=16.79 \quad \mathrm{p}=.0021$

There was a distinct positive relationship between rank and organisational commitment (as defined by MES) comparable to that found by Cotton (1980). That is, Officers were more institutionally committed to the Navy than Junior NCMs. This was a surprising result in view of the fact that Officers were found in earlier analysis (cf.p.45) to have higher intentions to leave than Junior NCMs. Consequently, Junior NCMs were more occupationally oriented in their attitudes towards the military than either Officers or Senior NCMs. This again raises the issue of military socialisation of entry level recruits which Cotton (1980) discusses at length.

Statistics highlight the fact that the maiority of the sample was in fact found within the neutral category (Table 16). 


\section{Table 16}

Descriptive statistics for MES

$\begin{array}{ccccc}\text { Mean } & \text { Median } & \text { Mode } & \text { Standard Deviation } & \text { Range } \\ 19.7 & 20.0 & 19.0 & 4.2 & 7-28\end{array}$

Frequencies found for the categories of military ethos scores (low $=15$ or $6.7 \%$; moderate $=156$ or $69.6 \%$; and high $=53$ or $23.7 \%$ ) suggested that most of the sample can be described as "ambivalent". That is, respondents exhibited the attitudes of both the institutionalised and occupational views. This was supported by the fact that a large proportion of the sample (41.9\%) indicated that their families were their first priority, not the Navy or their careers.

\section{5 - Job Satisfaction and Organisational Commitment Matrix}

It was proposed earlier (cf.p.78) that those members having high job satisfaction and high organisational commitment would be least likely to have intentions to leave the Navy. Conversely, those who had low job satisfaction and low commitment were the most likely to have intentions to leave the Navy. The question remained as to the intentions of those having high job satisfaction and low commitment or low satisfaction and high commitment.

A high-low job satisfaction and organisational commitment matrix was developed. To determine the matrix, composite scores for job satisfaction (adding 
values on all six scales of the JDI) and for organisational commitment (adding values from OCQ, MES and Forcho) were calculated. Scores were divided into three categories: high, moderate and low for each scale on the basis of percentiles. Crosstabulations were then found using these categories (Table 17).

\section{Table 17}

Matrix of Job Satisfaction and Organisational Commitment (cell \%)

organisational commitment

\begin{tabular}{|c|c|c|c|c|}
\hline & & low & moderate & high \\
\hline Job & low & $53.8 \%$ & $12.5 \%$ & $24.1 \%$ \\
\hline & moderate & $30.0 \%$ & $40.6 \%$ & $39.3 \%$ \\
\hline & high & $16.3 \%$ & $46.9 \%$ & $36.6 \%$ \\
\hline
\end{tabular}

The largest percentage was found to have low satisfaction and low commitment. The cell having the least percentage of respondents was the low commitment and high job satisfaction. With only cursory analysis, it does appear that one can be committed to the organisation, yet not satisfied with the job and vice versa. One does not preclude the other.

As intentions to leave became more unlikely, a higher percentage of members indicated high commitment and high job satisfaction (47.6\% Table 20) 
than when intentions to leave were likely (26.9\% Table 18$)$. Moreover, higher cell percentages were found for those cells with low and high combinations of job satisfaction and organisational commitment when intentions to leave were likely than when intentions were unlikely (Tables 18 and 20 refer).

Table 18

\author{
Matrix of Job Satisfaction and Organisational \\ Commitment (cell \%) \\ Intentions to Leave $=$ Likely
}

organisational commitment

$\begin{array}{lllcc} & & \text { low } & \text { moderate } & \text { high } \\ \frac{\text { Job }}{\underline{\text { Satisfaction }}} & \text { low } & 59.5 \% & 20.0 \% & 30.8 \% \\ & \text { moderate } & 21.4 \% & 20.0 \% & 42.3 \% \\ & \text { high } & 19.0 \% & 60.0 \% & 26.9 \%\end{array}$

Thus, when intentions to leave were likely (Table 18), the highest percentage of the sample (59.5\%) are found in the low commitment and low satisfaction cell. 


\section{Table 19}

Matrix of Job Satisfaction and Organisational

Commitment (cell \%)

Intentions to Leave $=$ Undecided

\section{organisational commitment}

$\begin{array}{lllrl} & & \text { low } & \text { moderate } & \text { high } \\ \frac{\text { Job }}{\text { Satisfaction }} & \text { low } & 71.4 \% & 0.0 \% & 15.8 \% \\ & \text { moderate } & 28.6 \% & 60.0 \% & 63.2 \% \\ & \text { high } & 0.0 \% & 40.0 \% & 21.1 \%\end{array}$

Table 20

Matrix of Job Satisfaction and Crganisational Commitment (cell \%) Intentions to Leave $=$ Unlikely

organisational commitment

$\begin{array}{lllcc} & & \text { low } & \text { moderate } & \text { high } \\ \frac{\text { Job }}{\text { Satisfaction }} & \text { low } & 43.3 \% & 11.8 \% & 20.6 \% \\ & \text { moderate } & 40.0 \% & 47.1 \% & 31.7 \% \\ & \text { high } & 16.7 \% & 41.2 \% & 47.6 \%\end{array}$

Consequently, when intentions to leave are unlikely (Table 20), the highest percentage of the sample $(47.6 \%)$ were found in the high commitment, high satisfaction cell. 
On the basis of this analysis, therefore, the matrix for job satisfaction and organisation commitment would be as follows (for simplification only a dichotomous, high - low matrix was used):

\begin{tabular}{|c|c|c|c|}
\hline & \multicolumn{3}{|c|}{ organisational conmitment } \\
\hline & & low & high \\
\hline$\underline{\text { Job }} \underline{\text { Satisfaction }}$ & low & $\begin{array}{l}\text { most likely to } \\
\text { leave }\end{array}$ & $\begin{array}{l}\text { more likely than } \\
\text { unlikely to leave }\end{array}$ \\
\hline & high & $\begin{array}{l}\text { more likely than } \\
\text { unlikely to leave }\end{array}$ & $\begin{array}{l}\text { most unlikely to } \\
\text { leave }\end{array}$ \\
\hline
\end{tabular}

\section{6 - Summary}

The inferential analysis discussed in this chapter has provided only moderate support for the turnover intentions model utilised in this study. The effects of rank and service, in particular, were unexpected but interesting results, when one considers that their influence was contrary to that cited in the theoretical literature and numerous empirical studies. The following chapter will discuss, in more detail, the findings of the study; provide possible explanations as to why the predictor measures influenced leave intentions in the way that was shown; and examine the propositions in light of the data analysis. 
105

Appendix 2

Cross Tabulation Tables

\author{
Table 8 \\ Cross Tabulation \\ Intentions to Leave by Rank Category
}

\begin{tabular}{|c|c|c|c|c|c|}
\hline Rank & $\begin{array}{l}\text { Count } \\
\text { Col Pct }\end{array}$ & $\underline{\mathrm{J}} \mathrm{NCO}$ & Sr NCO & Officer & $\begin{array}{l}\text { Row } \\
\text { Total } \\
\end{array}$ \\
\hline Category & & 1.0 & 2.0 & 3.0 & \\
\hline \multicolumn{6}{|l|}{ BEHINT } \\
\hline Likely & 2 & $\begin{array}{c}12 \\
23.5\end{array}$ & $\begin{array}{c}46 \\
35.4\end{array}$ & $\begin{array}{c}20 \\
52.6\end{array}$ & $\begin{array}{c}78 \\
35.6\end{array}$ \\
\hline Undecided & 3 & $\begin{array}{c}6 \\
11.8\end{array}$ & $\begin{array}{c}18 \\
13.8\end{array}$ & $\begin{array}{c}7 \\
18.4\end{array}$ & $\begin{array}{c}31 \\
14.2\end{array}$ \\
\hline Unlikely & 4 & $\begin{array}{c}33 \\
64.7\end{array}$ & $\begin{array}{c}66 \\
50.8\end{array}$ & $\begin{array}{c}11 \\
28.9\end{array}$ & $\begin{array}{r}110 \\
50.2\end{array}$ \\
\hline $\begin{array}{l}\text { Column } \\
\text { Total }\end{array}$ & & $\begin{array}{c}51 \\
23.3\end{array}$ & $\begin{array}{r}130 \\
59.4\end{array}$ & $\begin{array}{c}38 \\
17.4\end{array}$ & $\begin{array}{c}219 \\
100.0\end{array}$ \\
\hline
\end{tabular}

Chi-square D.F. Significance Min E.F. Cells with E.F. $<5$

11.44803

$4 \quad .0220$

$5.379 \quad$ None 


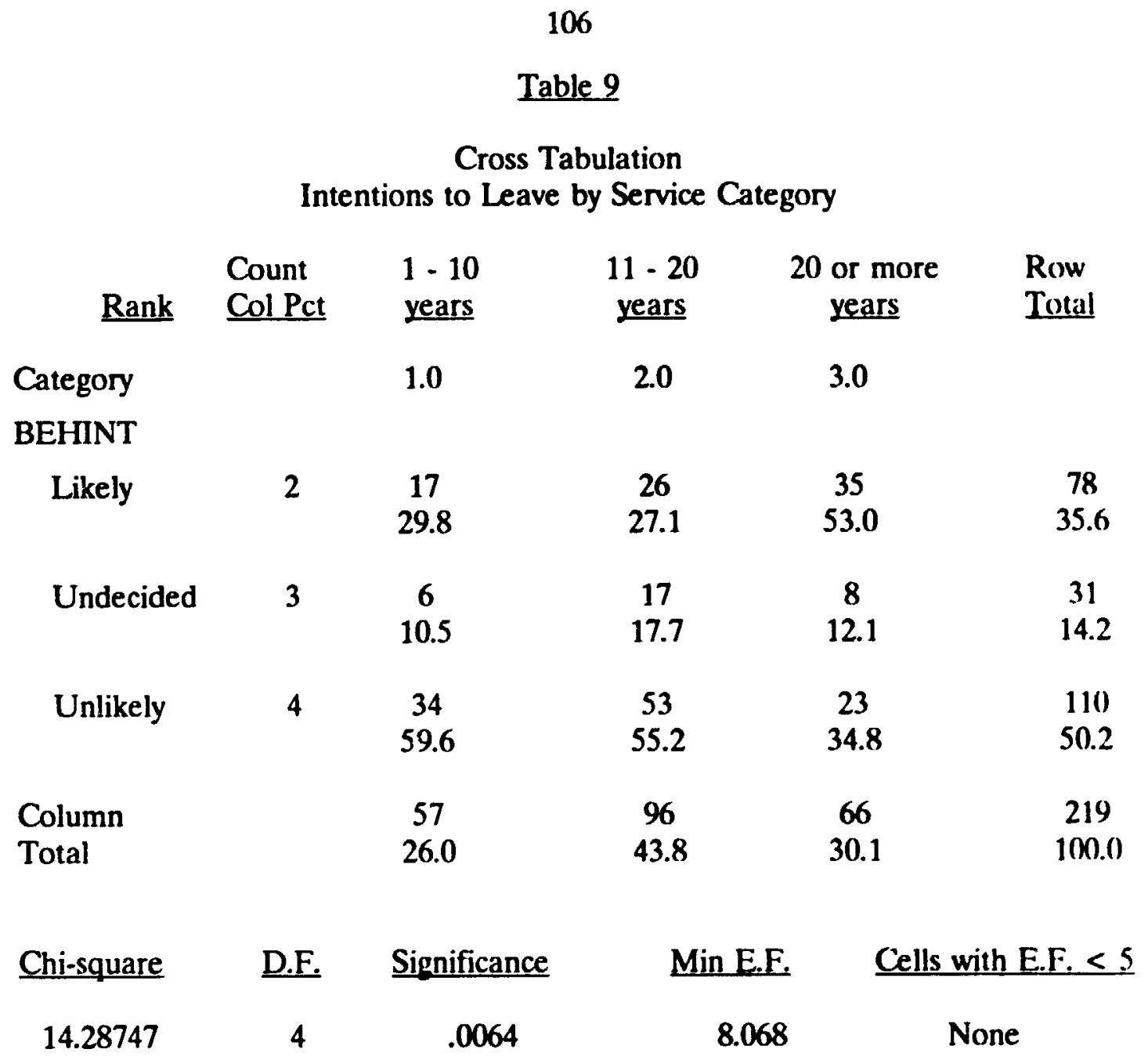


107

Table 10

Cross Tabulation

Intentions to Leave by Geographical Location

\begin{tabular}{|c|c|c|c|c|}
\hline Geological & $\begin{array}{l}\text { Count } \\
\text { Col Pct }\end{array}$ & East Coast & West Coast & $\begin{array}{l}\text { Row } \\
\text { Total }\end{array}$ \\
\hline \multicolumn{5}{|l|}{ BEHINT } \\
\hline Likely & 2 & $\begin{array}{c}40 \\
32.5\end{array}$ & $\begin{array}{c}38 \\
39.6\end{array}$ & $\begin{array}{c}78 \\
35.6\end{array}$ \\
\hline Undecided & 3 & $\begin{array}{c}20 \\
16.3\end{array}$ & $\begin{array}{c}11 \\
11.5\end{array}$ & $\begin{array}{c}31 \\
14.2\end{array}$ \\
\hline Unlikely & 4 & $\begin{array}{c}63 \\
51.2\end{array}$ & $\begin{array}{c}47 \\
49.0\end{array}$ & $\begin{array}{r}110 \\
50.2\end{array}$ \\
\hline $\begin{array}{l}\text { Column } \\
\text { Total }\end{array}$ & & $\begin{array}{l}123 \\
56.2\end{array}$ & $\begin{array}{c}96 \\
43.8\end{array}$ & $\begin{array}{c}219 \\
100.0\end{array}$ \\
\hline
\end{tabular}

$\begin{array}{rrrrrr}\text { Chi-square } & \text { D.F. } & \text { Significance } & & \text { Min E.F. } & \text { Cells with E.F. }<5 \\ 14.28747 & 4 & .0064 & 8.068 & \text { None }\end{array}$




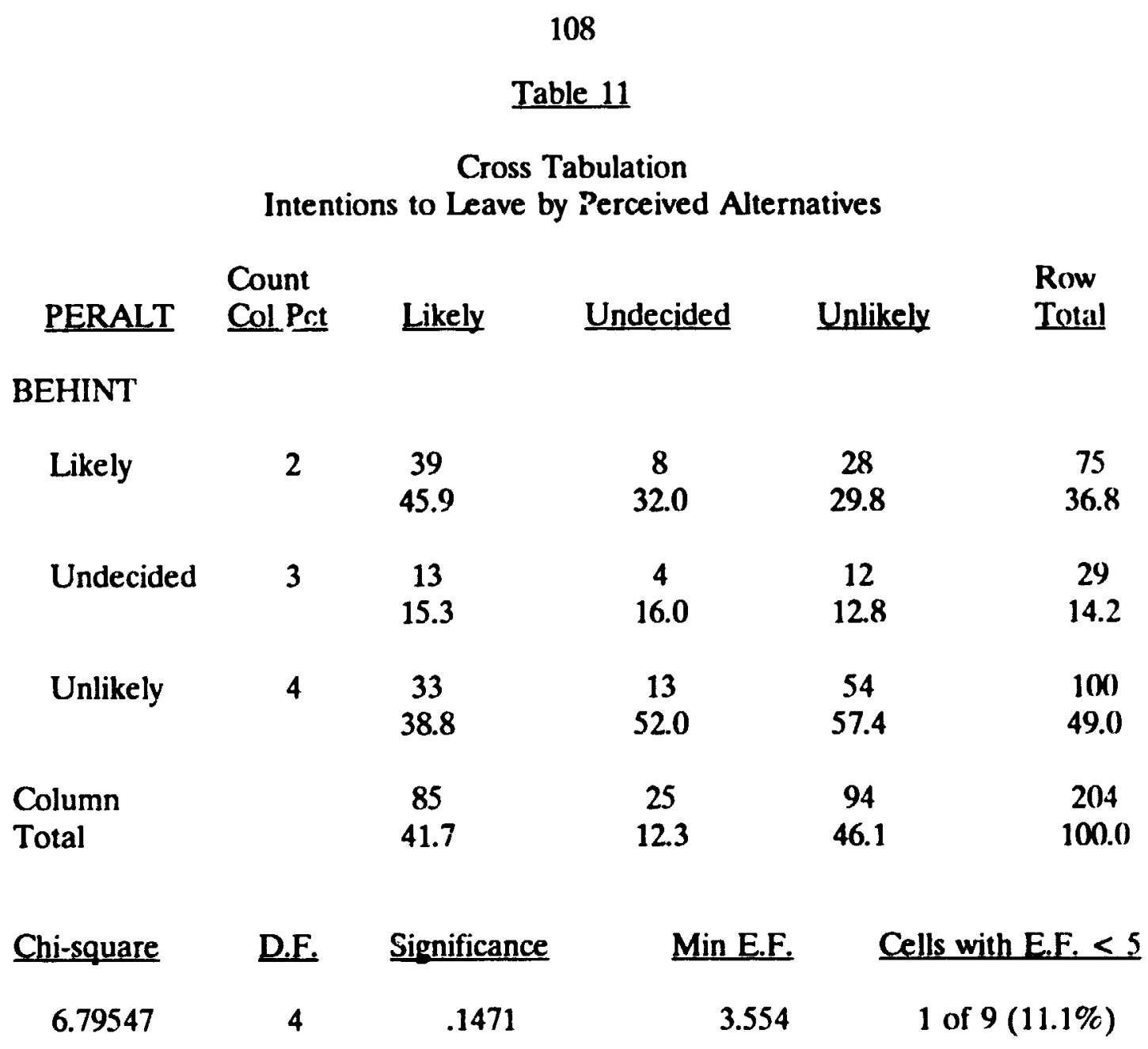


Appendix 3

Graphical Representations

\section{Eigure 3}

\section{Intentions to Leave by Rank}

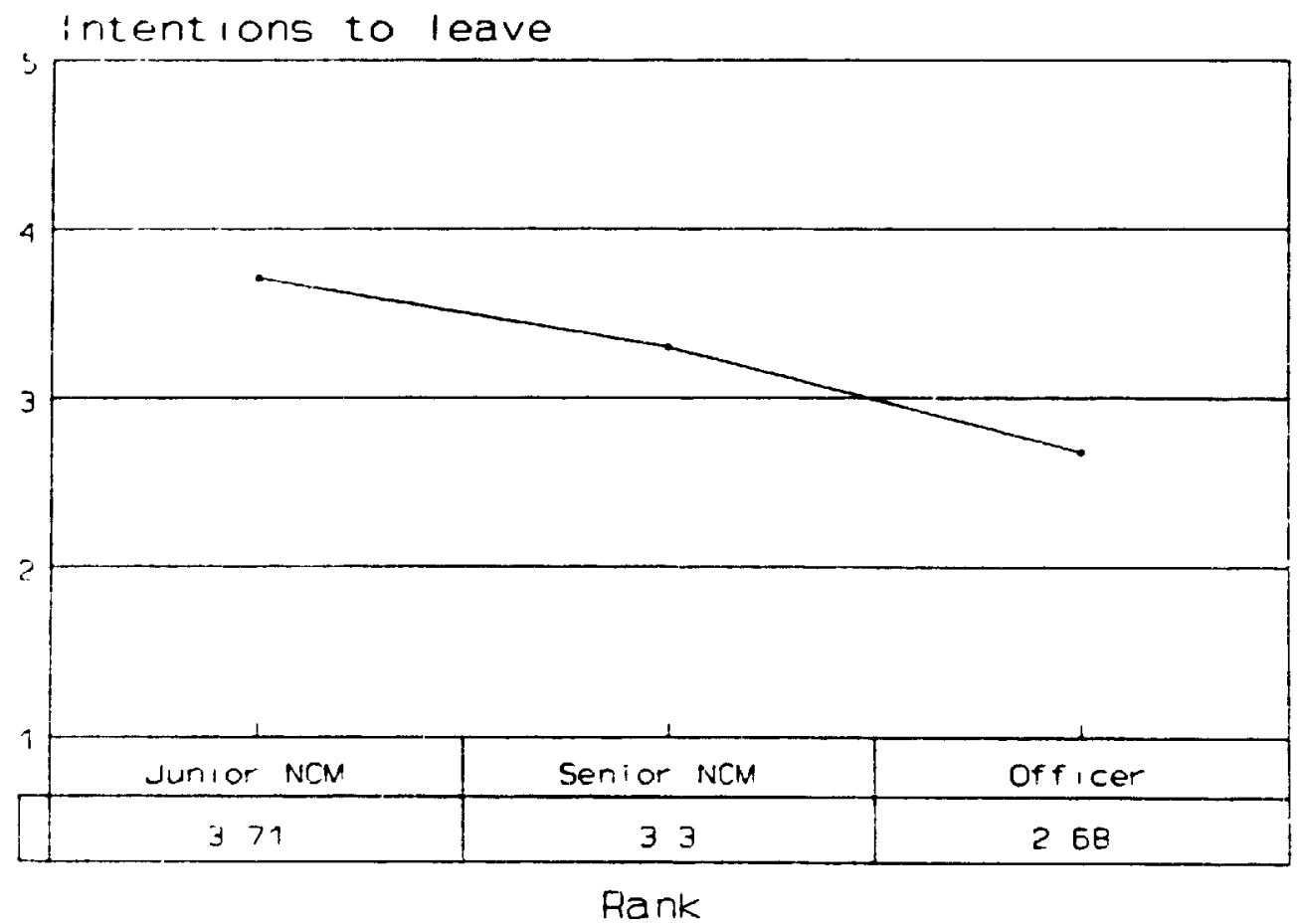

Source Dakes Surver 1991 
110

Figure 4

Organisational Commitment (OCQ) by Rank

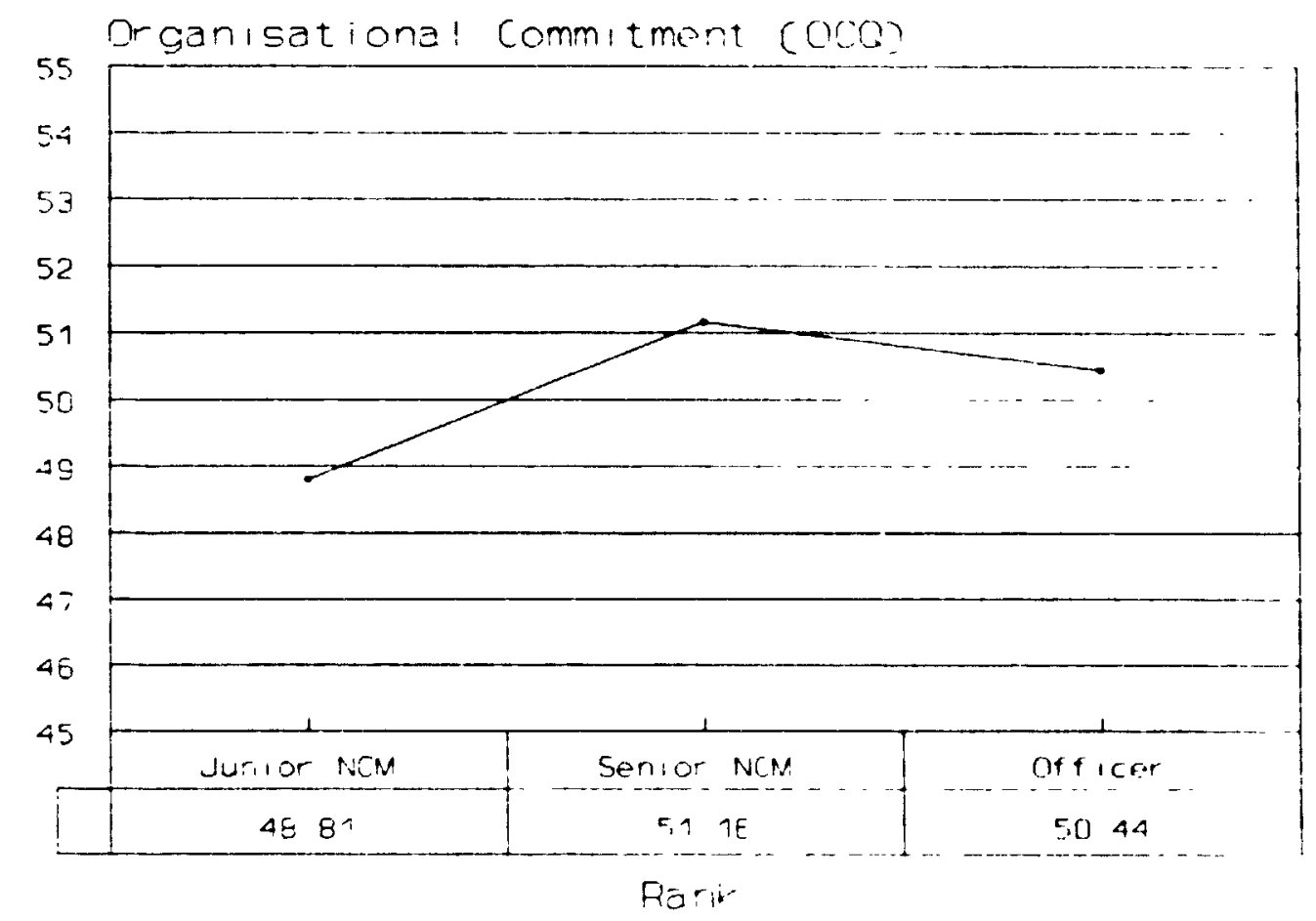

Source Dakes Survey 1951 
111

Eipure 5

Military Ethos Scale (MES) by Rank

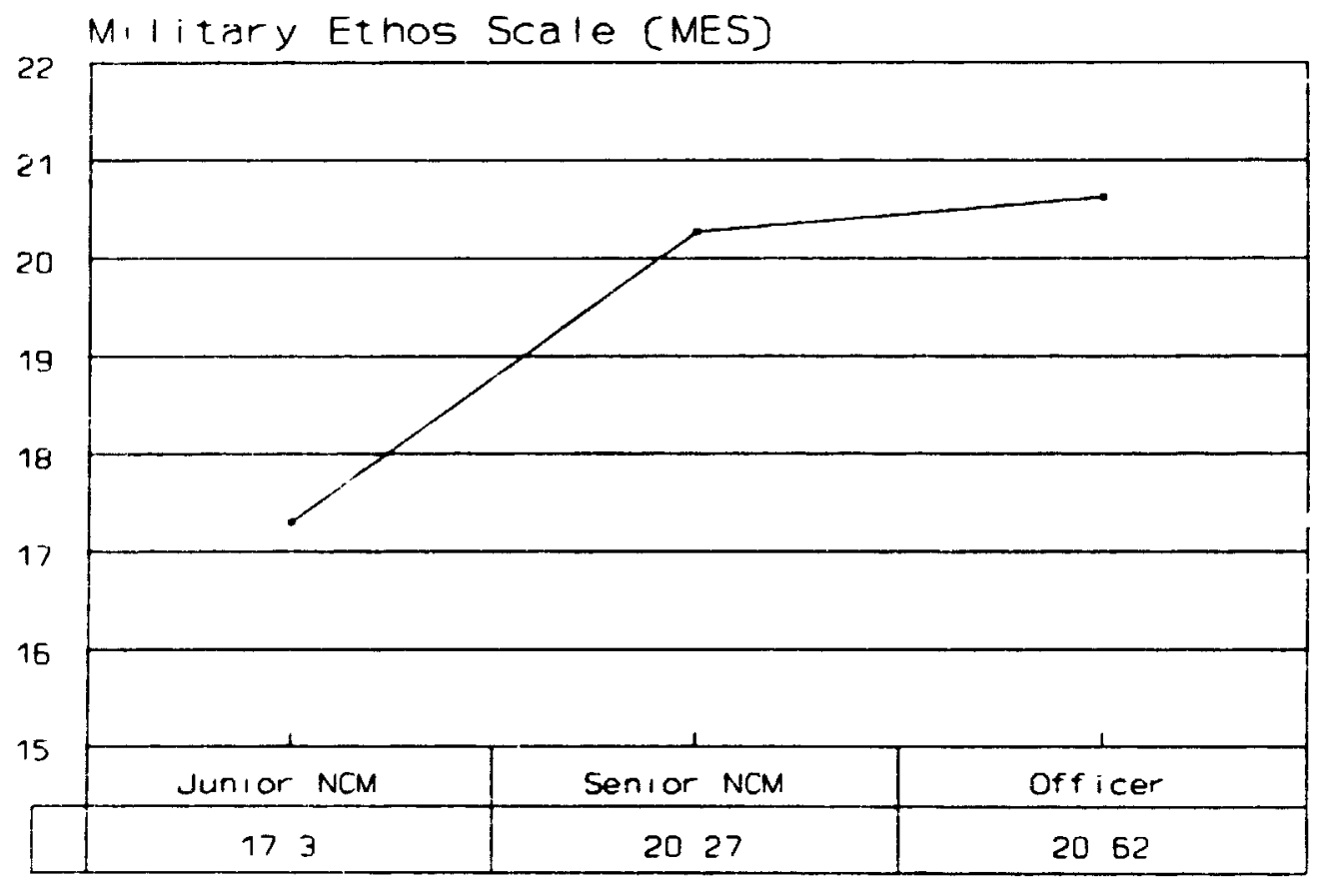

Rank

Source cakes Survey 1991 
Figure 6

\section{Job Satisfaction with Promotion by Rank}

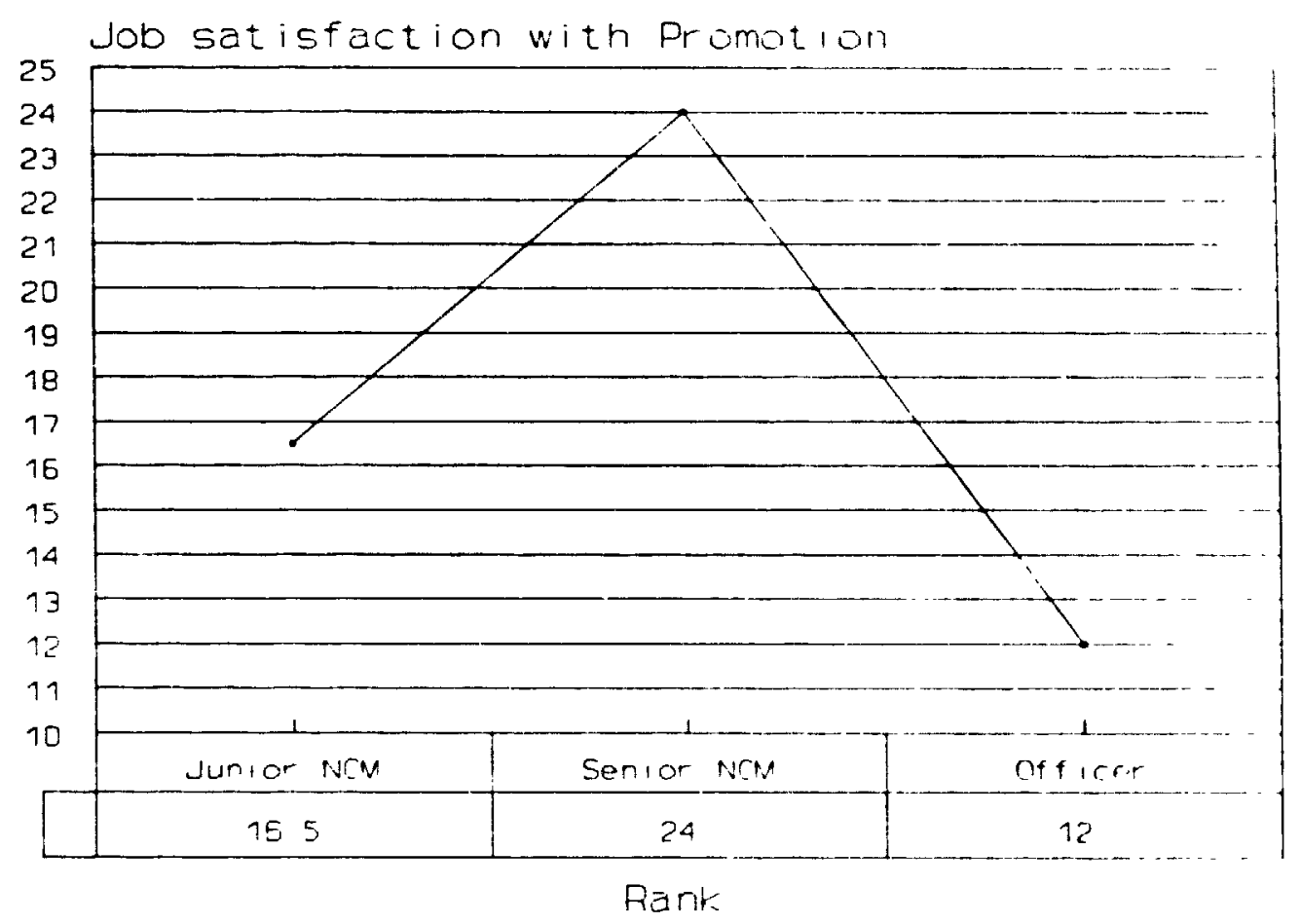

Source Cakes Survey 1991 
Figure 7

\section{Intentions to Leave by Service}

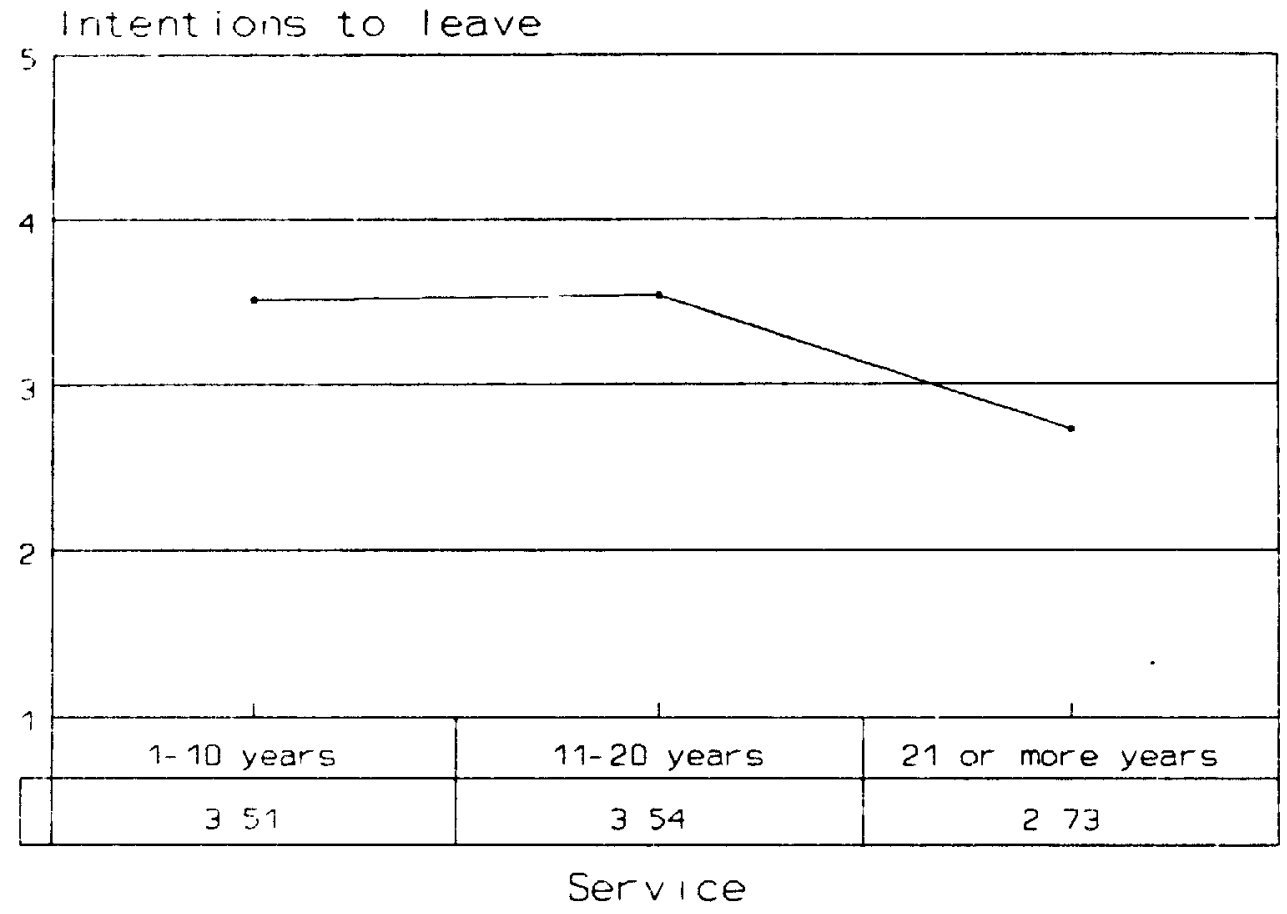

Source Oakes Survey 1991 
114

Figure 8

\section{Organisational Commitment (OCQ) by Service}

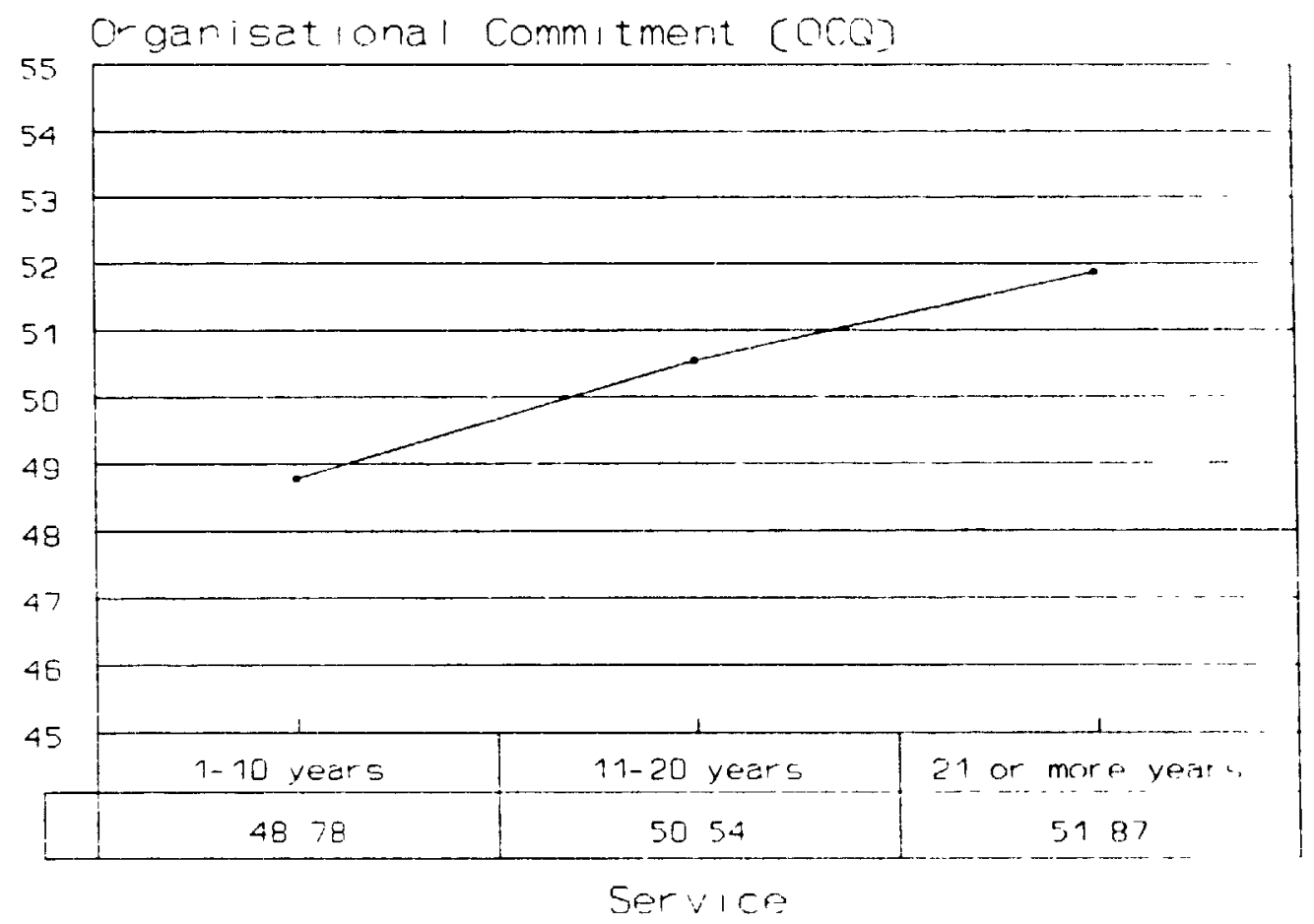

Soures Oakes survey 159? 
Figure 9

Military Ethos Scale (MES) by Service

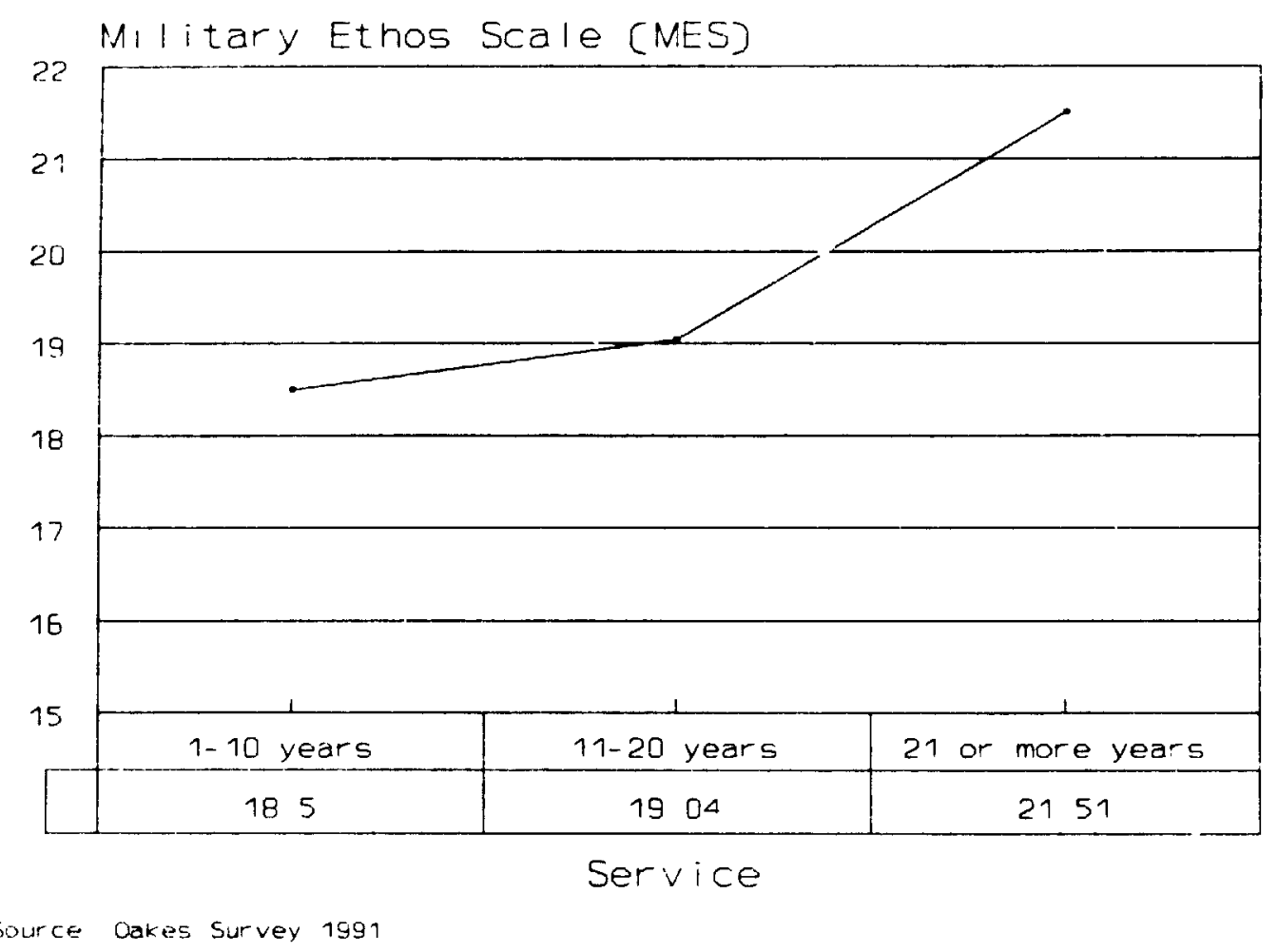


Figure 10

\section{Job Satisfaction with Promotion by Service}

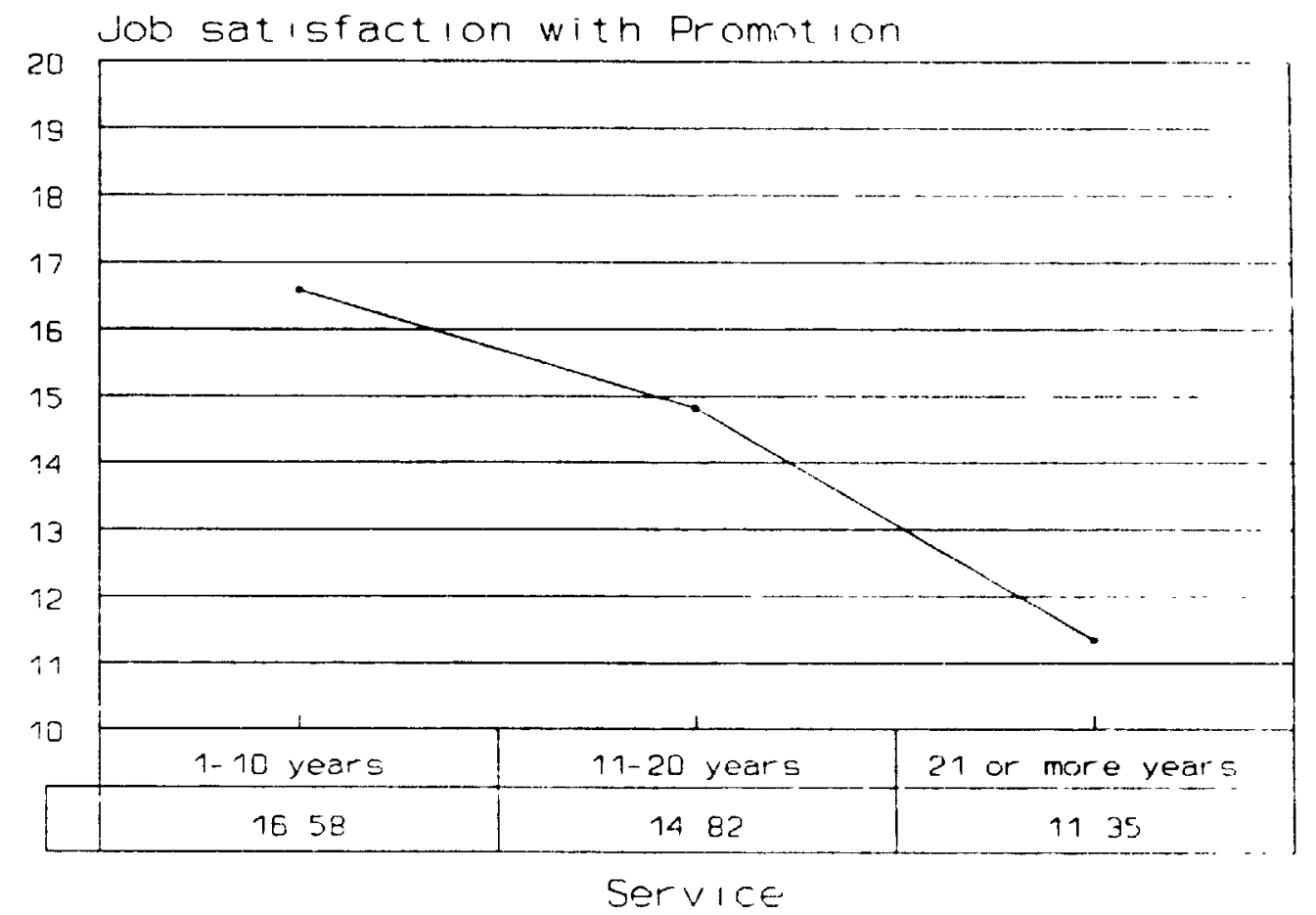

Source Dakes Survey 1997 
Fipure 11

\section{Intentions to Leave by Perceived Alternatives}

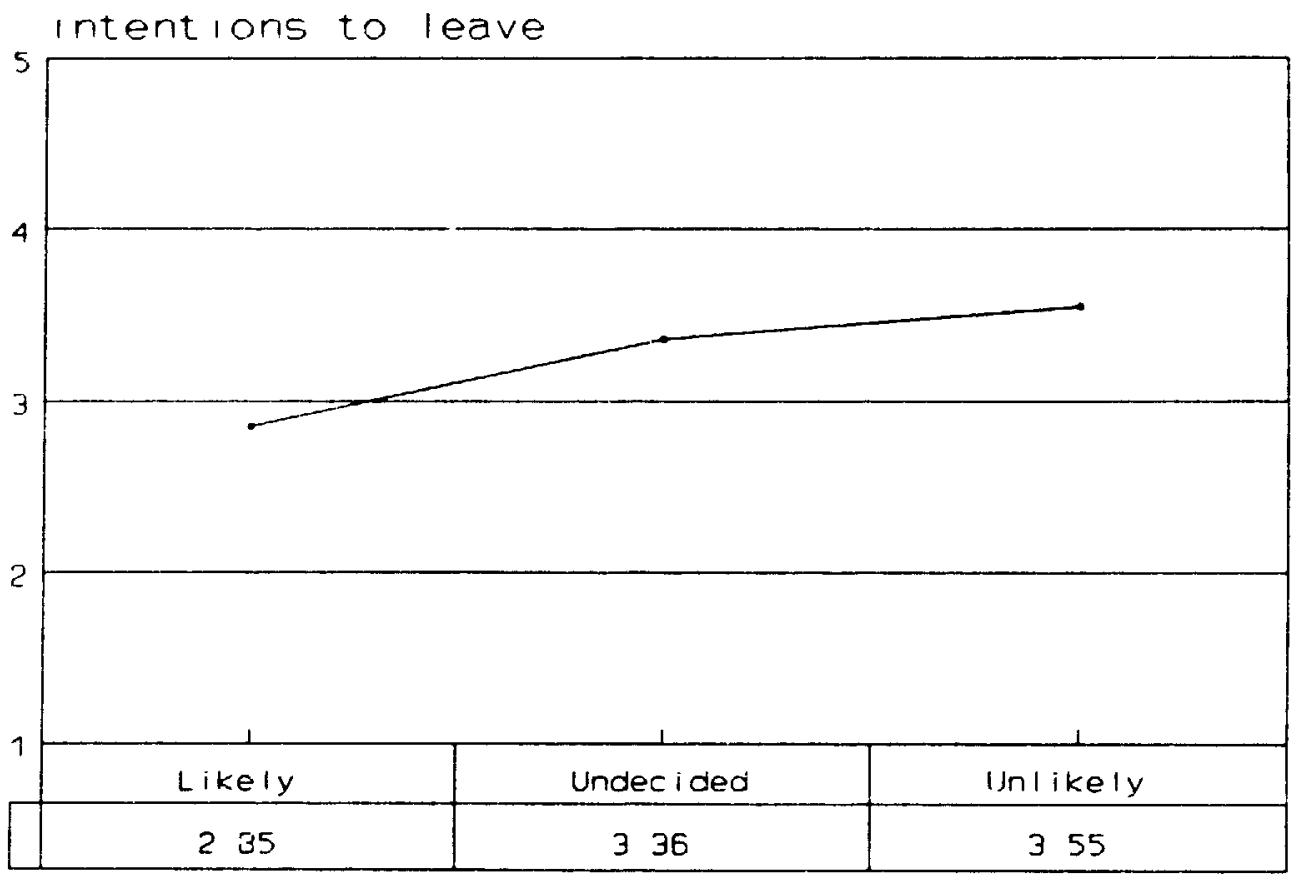

Perceived Alternat ives

Source Dakes Survey 1991 


\section{Figure 12}

\section{Organisational Commitment (OCQ) by Perceived Alternatives}

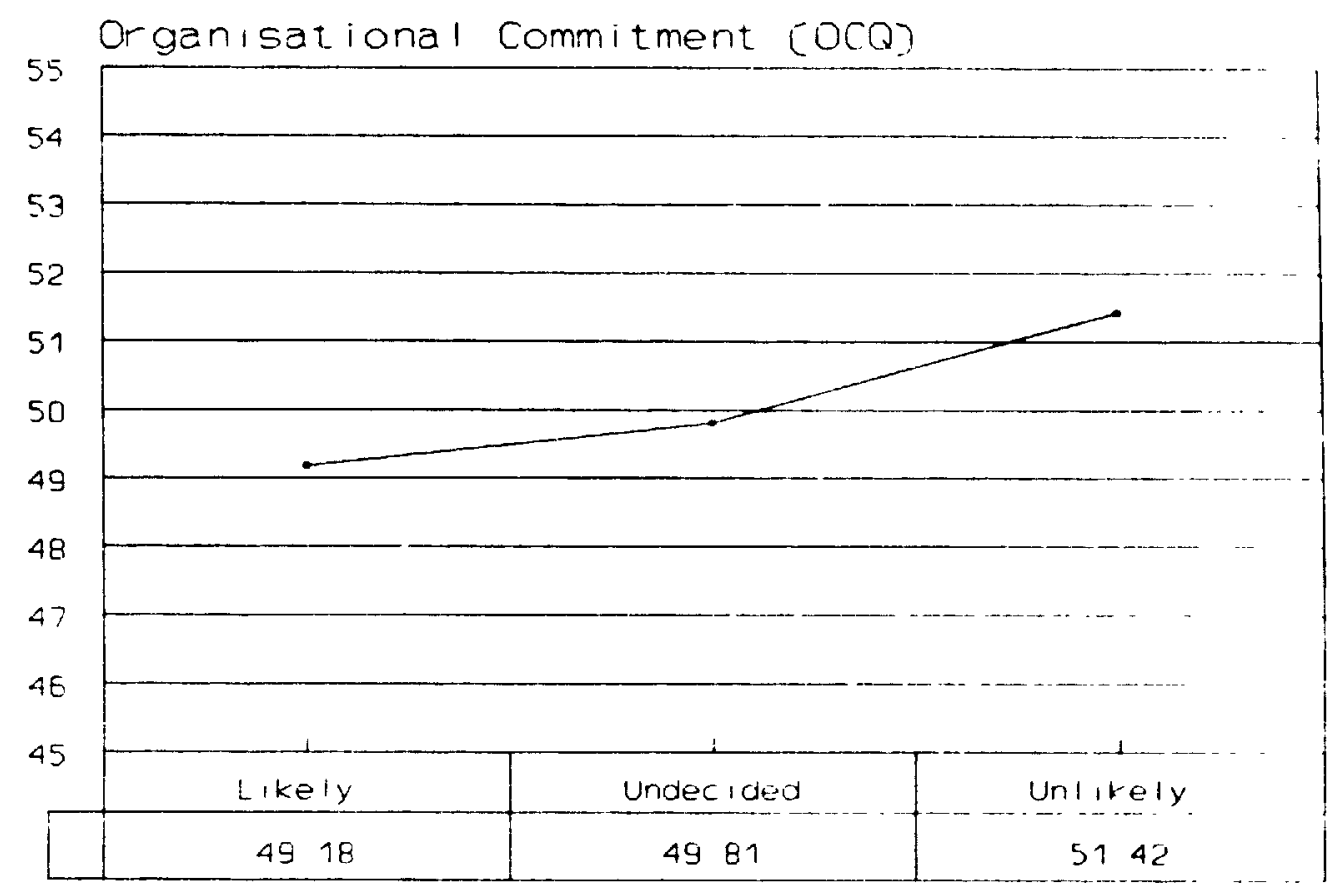

Perceived Alternat I ves

Source dakes Survey 199 ? 
Figure 13

Job Satisfaction with Position by Perceived Alternatives

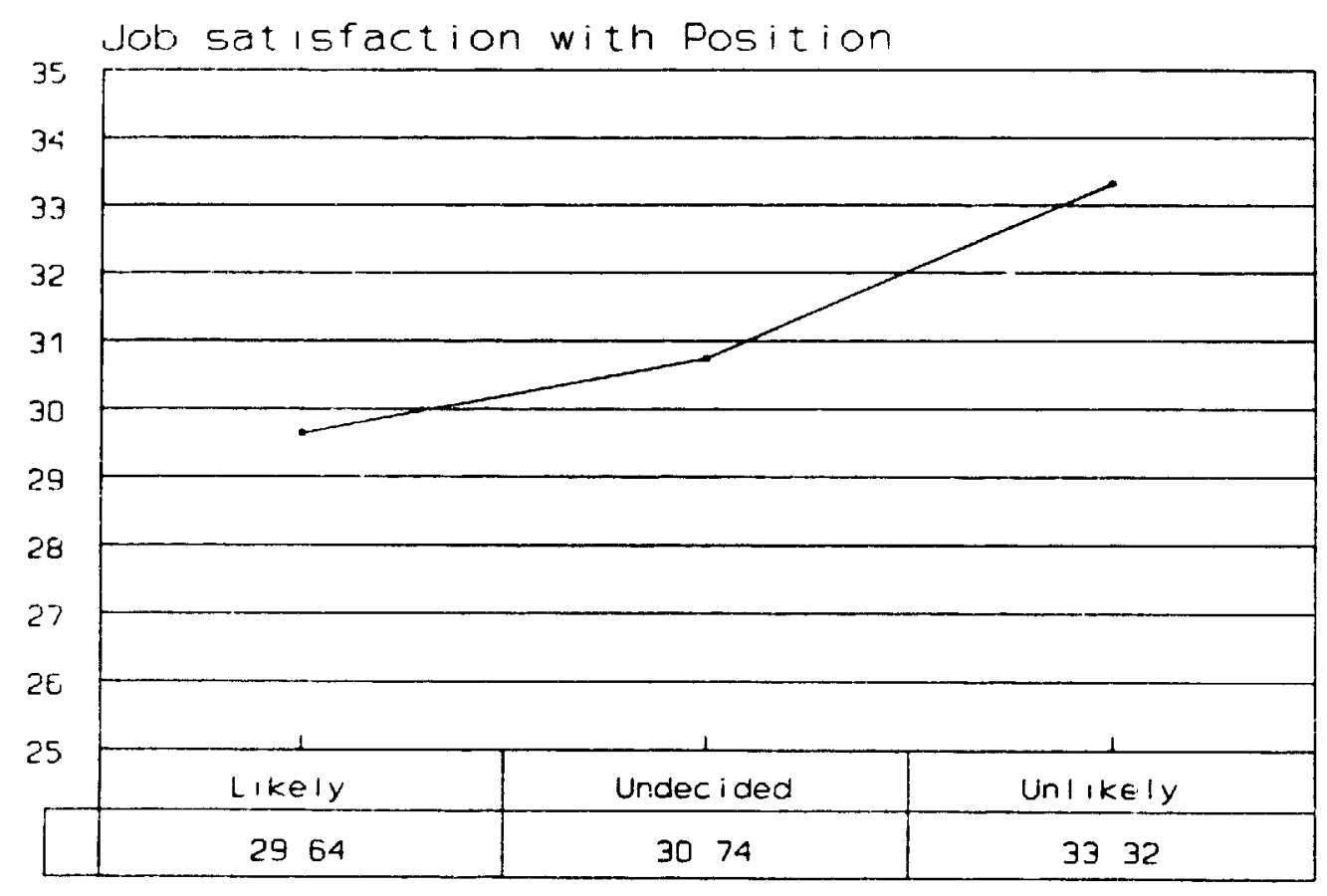

Perceived Alternat ives

Source Oakes Survey 1991 
Eigure 14

Job Satisfaction Overall by Perceived Alternatives

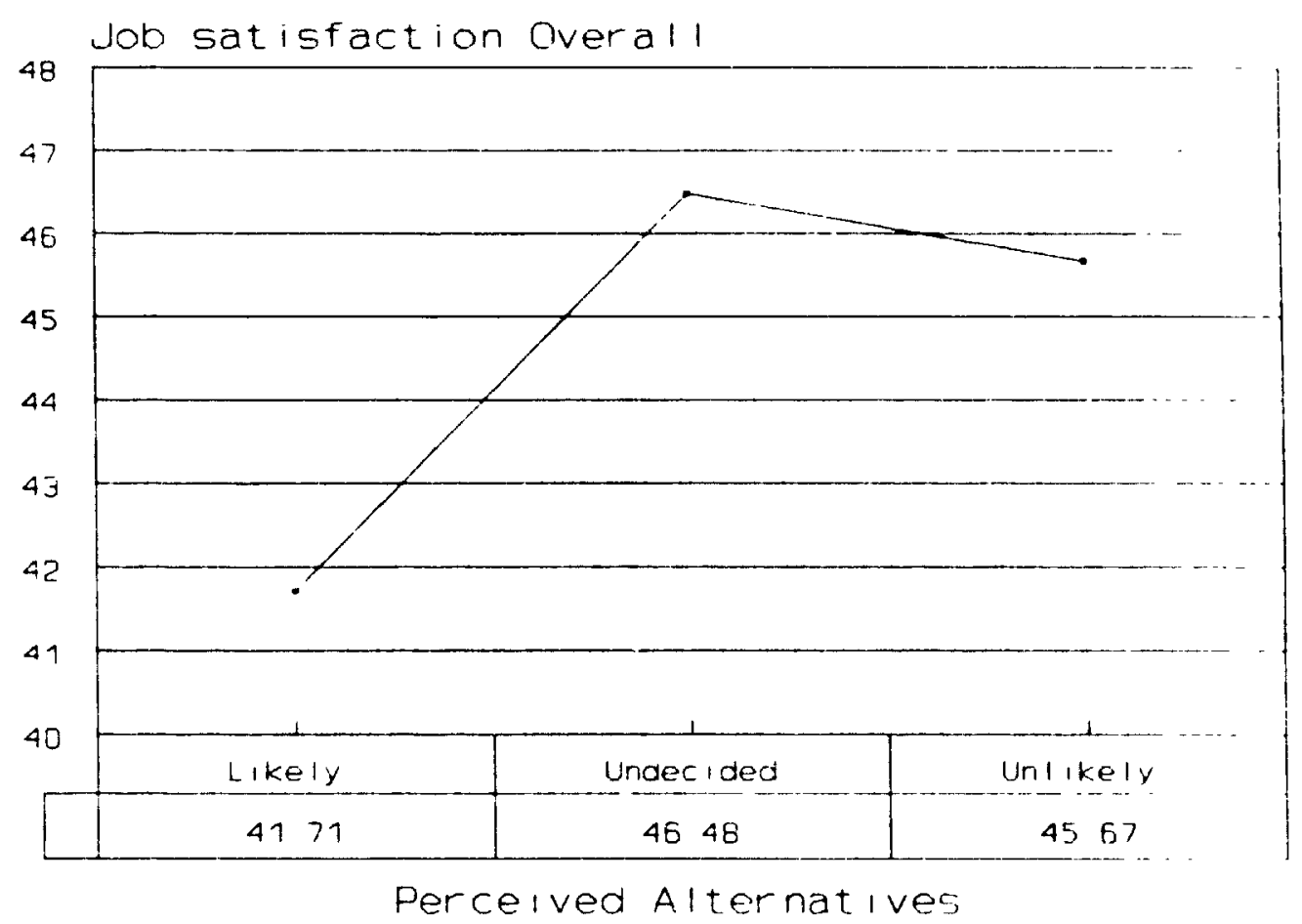

Source Dakes Survey 1991 


\section{CHAPTER 5}

\section{DISCUSSION}

\section{1 - Introduction}

This chapter discusses the results of the descriptive and inferential analysis of the data presented in Chapter 4. The more significant findings will be examined within the context of the turnover intentions model used in the study and the propositions proposed.

Eleven propositions were tested in this study based on the model of turnover intentions outlined in Chapter 2. Of those, four were supported; four were only partly supported; and three were not supported at all.

Those that received support were:

(1) turnover intentions were found to be least likely when job satisfaction and organisational commitment was high.

(2) turnover intentions were most likely when job satisfaction and organisational commitment was low.

(3) turnover intentions fell between these two extremes when job satisfaction was high and organisational commitment was low or vice versa. 
(4) the greater the environmental pull (perceived alternatives were more likely), the lower the organisational commitment and the more likely the intentions to leave.

\section{2 - Organisational Size}

Propositions concerned with three of the predictor measures: rank, service and organisational size were, at best, only partly supported by the research.

Organisational size, in particular, was not supported at all. From the outset, every preliminary analysis indicated that the size of the organisation had no influence on intentions to leave the Navy. The naval members on the West coast (Esquimalt) were just as likely to have intentions to leave as those on the East coast (Halifax) in spite of its smaller size (in terms of numbers of full time personnel). This may be reflective of the fact that size does not, in itself, enhance or prohibit commitment or satisfaction among its members. Other important factors which must be considered when this variable is examined, are span of control; centralisation of authority; organisational structure; and the formal and informal channels of communication.

The organisation of the two Fleet Schools is basically similar in terms of hierarchical structure; lines of formal communication; and role. The creation of an organisational climate conducive to promoting morale and commitment of its members is also, in large measure, a function of the particular leadership style of the officers commanding. Consequently, size of an organisation may have both 
positive and negative effects on commitment and satisfaction. On the one hand, it may increase opportunities for advancement and job enhancement. On the other, it may restrict participation in the decision making process. This is particularly true for complex, highly disciplined, restrictive organisations such as the military (Baba and Knoop 1987).

The issue of organisational size and its influence on commitment and job satisfaction is, therefore, a more complicated and comprehensive one than merely the numbers involved. Consequently, given this restriction, it was not surprising that no definitive difference was found between the Fleei Schools on the measures of organisational commitment, job satisfaction or intentions to leave.

\section{Environmental Pull (Perceived Alternatives)}

Environmental pull (perceived aiternatives) was found to be directly related to intentions to leave. Leave intentions became increasingly more unlikely as the alternatives to other employment declined. This variable is not only related to the perception of alternative employment opportunities outside the military but also to the actual availability of those opportunities in the labour market. Prevailing economic conditions have proven to play an important role on whether members stay or leave the Navy. Generally, as Canadian unemployment increases, members are more apt to choose the security of the military than the relative 
uncertainty of the "outside". Another factor which needs to be considered is the degree of skill mobility from a military organisation to a civilian one. Many of the occupations are highly skilled, technical trades, deemed by many, to be peculiar only to a Naval environment. Such technical specialisation and training may not be easily transportable to civilian occupations.

A study of Canadian Forces attrition conducted by Mendes and Lyon found that: "stayers in the sea element (Navy) reported nature of work (69.9\%) as a predominant factor which would influence potential leave decisions" (1984:24). Leavers reported $77.2 \%$ on this same factor (1984:24). The nature of the work, as an important criteria in whether one stays or leaves the military, constitutes what Mendes and Lyon (1984) term a "push" factor. This factor was evident in the present study which found that perceived alternatives and job satisfaction with position were positively related. The more satisfied members were with their present employment position, the less likely they indicated they would have, or would accept, alternative employment opportunities. Overall job satisfaction with the Navy suggested a similar, but not as definitive, finding. Those who indicated the likelihood of finding other employment were found to be the least satisfied with the Navy overall. The push factor is stronger for those dissatisfied members who, in turn, are the ones most likely to have intentions to leave. 


\section{4 - Rank}

One of the more salient findings that contradicted turnover theory and research was the fact that Officers, not Junior NCMs, were more likely to have intentions to leave the Navy. Several explanations could account for this finding. One is the issue of preconceived expectations of the opportunities offered in the Navy. Part of the attractiveness of any organisation is the perception by the employee of the congruence of his/her goals and expexted rewards with those of the organisation. The military actively seeks and recruits, particularly within the Officer Corps, those individuals who exhibit a high degree of initiative, leadership, sociability and communication skills. The military also attracts, at this level, in general, highly educated individuals with high achievement needs. In return, the organisation purports to offer excellent pay and benefits; professional development; availability of advanced technology to develop skills; and promotional opportunities.

When a discrepancy exists between individuals' expectations and those provided by the milita1.: dissension and dissatisfaction result. As Porter and Steers point out: "...those who remained, generally felt their original expectations were essentially met on the job, while those who left felt their expectations had not been me:" (1973:172). 
The Navy, in particular, has recently undergone considerable structural changes which have all but decimated its capability to do its job (German 1990). At the er 1 of WWII, the Navy consisted of 94,000 personnel and 400 operational ships. In 1990, it had a manpower level of 9500 and 21 ships, many of which required extensive refitting (German 1990). Capital spending projects have been discontinued, including the plan to build nuclear powered submarines. As one respondent in this study remarked: "continuous policy changes; shortage of manpower; and lack of equipment support over the last few years have been great dissatisfiers for both young and old". The Navy, therefore, because of these changes, has been unable to fulfill the high expectations of chailenge, adventure and advancement demanded of it by its members.

In an examination of voluntary releases, it was found that there was congruency between expressed intentions to leave and actual leaving behaviour. The actual number of voluntary releases for the Navy for years 1989 and 1990 appear to reflect these negative attitudes (Table 21). 


\section{Table 21}

Voluntary Releases for the Navy 1989 and 1990

\begin{tabular}{cccccc}
\multicolumn{2}{c}{ Officers } & \multicolumn{2}{c}{ Senior NCM } & \multicolumn{2}{c}{ Junior NCM } \\
1989 & 1990 & 1989 & 1990 & 1989 & 1990 \\
39 & 57 & 33 & 26 & 205 & 152 \\
$(10.6 \%)$ & $(20.2 \%)$ & $(26.6 \%)$ & $(24.8 \%)$ & $(15.7 \%)$ & $(13.6 \%)$
\end{tabular}

Notes: a. Figures exclude Officer Cadets and Ordinary Seamen under training

b. Percentages are \% of total Navy releases for each category

c. $\mathbf{N C M}=$ non-commissioned member

d. Source: Department of National Defence DPIS P9101006 April 1990.

The actual release figures appear to indicate that Officers are the most likely to leave the Navy. Voluntary releases for this group increased from 1989 to $1990(9.6 \%)$. Junior NCMs had the smallest release percentages than the other two groups in 1990 and showed a decline from 1989 to 1990 . Senior NCMs, who were found in the study to have less intentions to leave than officers, showed a $1.8 \%$ decrease in voluntary releases from 1989 to 1990.

Officers who, generally are more highly educated and professionally ambitious, may enter the Navy with higher expectations than others. Junior NCMs on the other hand are generally concerned with learning a skill that is transferable to civilian organisacions and receiving a good starting salary (a newly recruited Ordinary Seaman, for example, earns a gross annual salary of $\$ 14,150$ (DPS April 90). This compares to $\$ 11,232$ for those starting at a minimum wage 
of $\$ 5.40$ per hour (Employment and Immigration 1991). Officers, on the other hand, may be more concerned with more esoteric, intrinsic rewards, such as professional challenge, advancement and recognition of abilities. Money, in itself, is not a motivator. Consequently, as Mowday and Steers point out: "...employees who enter organisations with more realistic expectations are less likely to voluntarily leave than those with unrealistic expectations" (1977:172). More importantly, commitment is influenced by how much those expectations have been realised.

Officers were also found to be the least satisfied with promotion. Senior NCMs, on the other hard, were the most satisfied on this measure. All military members, regardless of rank, expect advancement (promotion) as a reward for their competency, dedication to duty and loyalty. This is particularly true for Officers not only because of the more salient status it brings but also because of the concomitant expansion of responsibilities and job challenge. When advancement is not forthcoming, not only does professional frustration result, but also positional stagnation.

With the exception of promotion to Lieutenant-Commander, promotions for the Officer classifications declined from 1989 to 1990 (Table 22). Opportunities for advancement, therefore, became more limited. This is particularly true for Commander rank which is a critical career point for Mars 
(Maritime Surface and Subsurface) Officers, since at this rank, those fortunate to be selected, will have command of their own ship. One respondent rem rked that: "promotion opportunities are good when you start. There is less opportunity for promotion as you advance (in years of service)". Not only Officers but those longer serving Officers showed the most dissatisfaction with promotion (Oakes survey 1991).

\section{Table 22}

Officer Promotion for Naval Occupations for the Years 1988 to 1990

\begin{tabular}{cccccccccc} 
& \multicolumn{2}{c}{$\begin{array}{c}\text { To } \\
\text { Commander }\end{array}$} & \multicolumn{4}{c}{$\begin{array}{c}\text { To } \\
\text { Lieutenant } \\
\text { Commander }\end{array}$} \\
& & & \multicolumn{4}{c}{$\begin{array}{c}\text { To } \\
\text { Lieutenant(N) }\end{array}$} \\
& 88 & 89 & 90 & 88 & 89 & 90 & 88 & 89 & 90 \\
MAR!: & 9 & 10 & 5 & 23 & 2.6 & 26 & 67 & 79 & 79 \\
& $4.2 \%$ & $5.9 \%$ & $3.1 \%$ & $4.7 \%$ & $5.6 \%$ & $5.9 \%$ & $7.8 \%$ & $7.5 \%$ & $7.2 \%$ \\
MARS & 12 & 13 & 10 & 14 & 28 & 37 & 59 & 71 & 54 \\
& $5.6 \%$ & $7.9 \%$ & $6.2 \%$ & $2.8 \%$ & $6.0 \%$ & $8.3 \%$ & $6.8 \%$ & $6.8 \%$ & $4.9 \%$
\end{tabular}

Notes a. Percentages are of total Officer promotions for all classifications

b. MARE = Maritime Engineering; MARS = Maritime Surface and Subsurface.

c. Source: Department of National Defence. Canadian Forces Personnel Newsletter Issue 11/90.

Unfulfilled expectations of advancement, in addition to the discouraging prospect of outmoded equipment and training, lend support to the fact that Officers, in the sample were less organisationally committed to the Navy than Senior NCMs. This reflects the dynamic nature of the commitment process - "the 
process through which commitment is developed may involve self-reinforcing cycles of attitudes and behaviours that evolve on the job..." (Mowday and Steers 1981:3).

That is not to say that Senior and Junior NCMs do not get frustrated and discouraged with regards to the declining state of Canada's Navy. They do. Personal interviews with respondents, however, indicated that they were more hopeful than Officers to a return to the 'old ways' when the Navy fulfilled its responsibilities in the highly professional and competent manner it once did and was respected as the senior service. "We have highly skilled and dedicated group of people", one senior U!'ficer remarked, "now all we need is the equipment". A Chief Petty Officer said: "I'm still waiting and hoping for a return to an operational, efficient, effective Navy. I just hope in the long run that I won't be disappointed". The recent, highly publicised resignation (April 1991) of Vice-Admiral Thomas, at the time the most senior serving Naval Officer, was a reflection of the feelings of many Naval personnel to the declining state of Canada's Navy.

\section{$\underline{5.5 \text { - Service }}$}

Findings in the study suggested that those members of the Navy with more than 20 years of service indicated that they were the most likely to have intentions 
to leave the organisation. A parsimonious explanation wouid say that this group was reaching retirement age (55) and had to leave in any case. However, the fact that this group was also the most dissatisfied with advancement opportunities, lends itself to a more in-depth explanation. It may be possible that many of this 'older' group suffered from career stagnation - the realisation that promotional opportunities were limited and challenges of employment were few. They, consequently, may have reached a professional impasse, where they had too much time invested in the Navy and not enough time remaining, to warrant further training; learn new challenges; and be given new responsibilities.

It may also be a question of priorities. At the advanced stage in a person's career, family life may be a more important consideration than professional advancement, particularly when one has accepted the realisation that he/she has reached the 'pinnacle' of one's career. In the sample, $71.9 \%$ placed family as first or second in importance. Demands of family life are taking precedence over the demands of the military. As Segal contends: "the current competition between the military organisation and the family is occurring in a period of such social change...that it will lead to new normative patterns for resclving the conflicts" (1986:32). It appears that longer serving members, in particular, are resolving this conflict in favour of family life. 
Ironically, longer serving personnel were the most organisationally committed. This is not necessarily a contradiction in findings. Commitment may be a consequence of a socialisation effect. Those who have spent more time in the military have developed positive values quite distinct from those related solely to their employment. The military is a closed institution which, by definition, fosters a kind of camaraderie, loyalty and pride quite unlike that found in other organisations. Junior NCMs, on the other hand, have not had enough time in, or experience with, military life to develop the intrinsic values and attitudes which are associated with high commitment. They are in, what Mowday and Steers (1981) refer to as, the "initiation" stage of the commitment process. Through training, employment and association with longer serving members Junior NCMs, in time, learn the military attitudes and values expected with membership in this organisation. Consequently, "the socialisation of individuals...appear to represent important influences on the propensity of employees to become committed to organisations" (Mowday et al 1981:7).

The same intrinsic factors (family considerations) which encourage longer serving members to have intentions to leave, may, at the same time, encourage, those with less service to stay. The 11-20 year career stage was found to be a 'critical' period in the development of satisfaction and commitment; they were the least likely to have intentions to leave the Navy. In terms of professional development and advancement, those having 11-20 years of service may reach a 
career point where, they have enough time with in the organisation to have seniority and maturity and to have completed all their training, to the extent that they now become valuable assets to the organisation. Yet, at the same time, they believe they have sufficient years remaining to realise and fulfill their ambitions and expectations.

In addition, family considerations involving the expense of children's education and upbringing, house mortgages and spouse's employment, may preclude leaving the organisation for purely financial concerns alone. The proximity to pension entitlements, for most at the 20 year point, may have influenced leaving intentions for this group. Rawlinson (1978) referred to this as 'the golden handcuffs effect' - the inducement to serve 20 years even when commitment declines.

Thus, longer tenure, in itself, does not ensure commitment to an organisation. Concomitant with service must be the perception that an individual's goals and expectations have been fulfilled, as well as the careful weighing of other priorities which make comparable demands on the military member. 


\section{6 - Job Satisfaction}

Only two of the 6 scales of the Job Descriptive Index - satisfaction with promotion and overall were found to have an influence in this study. Speculation as to why pay and benefits, satisfaction with supervisors and co-workers were shown to have little or no effect may reflect the fact that, for this sample, these factors were simply not considered important.

A comparison of the median scores on the JDI scales from the sample to those normative scores at the 50th percentile rank found by Smith, Kendall and Hulin was drawn (Table 23).

\section{Table 23}

Survey Sample Median JDI Scores and Normative Scores at 50th Percentile

Job

$\underline{\text { Satisfaction }}$

with promotion

with pay/benefits

with position

with co-workers

with supervisors

overall
Median score

from sample

26

36

33

45

49

46
JDI scale

$\underline{50 \text { th \%ile }}$

18

30

38

46

44

44 
On all but two measures (with position and only slightly for co-workers), the Navy sample rated higher than the normative sample from Smith et al (1969). Though not conclusive, the comparison suggests that the Navy personnel sampled are generally satisfied with these factors - with pay and benefits and with supervisors in particular.

The military, relative to other comparable organisations, provides excellent pay and benefits. Starting gross monthly salary for an Acting Sub-Lieutenant, for example is \$2000; a Chief Petty Officer First Class may earn up to $\$ 4333$ gross per month (DPS pay guide April 1990). This does not include free medical and dental services; paid annual leave; and pension entitlements.

With regards to the median scores of the sample found for satisfaction with co-workers and supervisors, a possible explanation as to why the sample rated comparable with the former and above the latter may point to the integrity of the Navy community, in particular, and the : itary, in general. Naval personnel undergo extensive selection and training. As a consequence, they develop a professional work ethic and are perceived as having comparable worth in terms of their skills and abilities. This, together with the fact that the Navy is considered to be a highly disciplined organisation with little tolerance for insubordination, precludes overt criticism either of one's peers or one's superiors. 


\section{7 - Organisational Commitment}

The Navy sample had a median OCQ score of 3.40 on a 5 point Likert scale. This was almost identical to the normative score, based on a sample of 978 males, in the study by Mowday et al (1979) of 3.39 on a similar scale.

The mean OCQ found for the Navy sample was 3.37. Mowday et al (1979) found mean OCQ scores of 3.21 and 3.14 for public and university employees, respectively. Thus, the Navy sample proved to be equal to or more committed to the organisation, when compared to other groups.

Caution, however, must be exercised when one interprets the results. The Navy is a unique organisation in terms of its role and the demands placed upon its members. Since normative organisational commitment values have yet to be developed for similar institutions, it is difficult to make valid comparisons to other groups without runnirg the risk of drawing wrong conclusions. In addition, the OCQ measure developed by Mowday et al does not take into consideration the peculiarities of military terminology. It is possible, therefore, that errors of content validity may have occurred in this study. 


\subsection{1 - Institutional and Occupational Commitment}

The Navy sample had a mean Military Ethos Score of 19.65. The majority were found to be in the neutral or 'ambivalent' category. It appears that other priorities, such as the family, are taking precedence over a Navy career as one's only interest.

This is not necessarily a negative consequence. The military, in general, and the Navy, in particular, are, like most organisations subject to societal changes. More importantly, they must be receptive and adaptive to these changes. The dynamic nature of the organisation necessitates adjustments to its structure and its culture in response to 'outside' demands. It is possible to be both highly committed (institutional) to the Nay yet, at the same time, be committed to other institutions such as the family or professional organisations (occupational). Commitment is no longer perceived as a zero sum concept, where commitment to one precludes commitment to another. It is, what Janowitz (1977) referred to, as "pragmatic professionalism". This orientation appears (needs) to be the prevailing attitude of the military in future. As one respondent wrote, when referring to the problem of having to move frequently: "Career managers merely plug holes and consider the needs of the service. At some point we will have to realise that this is an expensive way to do business and recognise that individuals too have needs". There is some indication that the military is beginning to adapt to changing 
personal and professional demands as in the case of accommodating dual-service couples and single-parent families.

Ironically, this attitude will strengthen, not lessen, commitment of Navy members. The perception that the Navy is concerned as much with one's family, goals and expectations as it is with one's productivity and efficiency, will reinforce and strengthen existing ties between it and its personnel. "To the extent that the military works to incorporate the family within itself and adapts to it, the result will not be institutional change but preservation of the institutional nature of the military organisation" (Segal 1986:34).

\subsection{The Model of Turnover Intentions}

The results of the research did not lend significant support to the model of turnover intentions proposed. Although the predictor measures each influenced inientions to leave the Navy, rank and service did so in ways not predicted. In view of the preponderance of literature which supports the opposite effect, one can only conclude that the findings reflected the true attitudes of the sample. Logical explanations provided, in addition to actual voluntary release figures, certainly lend support to this conclusion. 
The JDI and organisational commitment measures, when used as predictor variables, did support the model contention that these concepts were negatively related to intentions to leave. However, regression and path analysis found that only two of the job satisfaction and one of the organisational commitment variables did, in fact, influence the criterion measure. Direct effects from these measures were, in most cases, larger than those for the predictors. What is particularly puzzling is the relatively few interactions between the independent and intervening variables on leave intentions. The model proposed that job satisfaction and organisational commitment would act as intervening variables to enhance or change the intentions to leave. This did not happen. These measures had little or no influence on the relationship between the predictor and criterion measures. In addition, interactive effects, which did occur, appeared to be additive rather than multiplicative in nature.

One possible explanation may be found in the particular dynamics of the model itself. The model assumed uni-directional, linear influences. It did not account for the possible cyclical nature of the process of commitment and satisfaction. There may have been a feedback loop mechanism operating, unseen and immeasurable, which was self reinforcing. Also implicit in the model but difficult, if not impossible to assess, was the individual's cognitive evaluation of the factors which determine and influence his/her decision to stay or leave the organisation. Thus, the model precludes the analysis of individual differences in 
the decision making process. This would account, in part, for the lack of significant interaction effects.

Another reason could have been the choice of variables themselves. Either they were ones that, by definition, would not produce interactions in any case rank and service being attribute measures and job satisfaction/organisational commitment were attitudinal measures, or there were other variables involved in the process which were not considered in the study - age, performance, job content, for example. Turnover intentions appeared to have been more multi-faceted and complex than anticipated or captured in the study. The fact that the variables under consideration in this study accounted for only $30 \%$ of the variance in the criterion measure lends credence to this explanation.

The limitations of the findings could also point to the inadequacy of some of the analytical trechniques used, path analysis, in particular. As Williams and Hazer found in their study: "it (path analysis) does not allow for the simultaneous examination of the effects of exogenous variables on two or more endogenous ones....Its use precluded addressing the question of the direct effects of determinants on both satisfaction and commitment at the same time" (1986:229).

As a consequence, the question of causality remains unanswered in this study. It cannot be concluded, from this research, that rank, length of service, or 
environmental pull causes intentions to leave or even that job satisfaction and organisational commitment have causal effects - "correlation is not causality". At best, there are causal linkages. In what direction, and to what extent, these effects were influential, is still questionable. Again, much of the behaviour of the criterion measure (intentions to leave the Navy) was not explained by this research.

The following chapter will provide the methodological limitations to the study of job satisfaction and organisational commitment, in general, and as they apply paricularly to this resea ${ }_{1} \mathrm{ch}$, as well as implications for future research. Possible policy implications for the Navy and the military, as a whole, will also be discussed. 


\section{CHAPTER 6}

\section{CONCLUSIONS}

\section{1 - Introduction}

The focus of this study has been on the concepts of job satisfaction and organisational commitment and their relation to intentions to leave within the context of a model of turnover intentions proposed by Mobley et al (1979). This chapter will examine several of the methodological issues of empirical research related to these concepts; the limitations of the study itself; and policy implications of the findings for the Navy, in particular, and the Canadian Armed Forces, in general.

\section{2 - Research concerns}

Studies of organisational commitment and job satisfaction have inherent problems related to methodological, measurement and conceptual issues. Those particularly related to the present researcin will be discussed. 
Methodological and conceptu: issues

The majority of research related to organisational commitment and job satisfaction has been of a cross-sectional nature, that is, studying these concepts at one point in time. The difficulty, of course, is that these studies have ignored the commitment/satisfaction processes which develop over time. Commitment and job satisfaction are ever-changing, dynamic phenomena, rather than static, passive states. There is, consequently, a need for more longitudinal research and the investigation of the factors necessary to promote and sustain commitment and satisfaction over time. Only through longitudinal designs can one capture the reciprocal relationship between commitment and satisfaction, on the one hand, and those between their determinants and effects on the other. Stumpf and Hartman used a longitudinal research desıgn in their study of commitment and found only moderate support for a process model. The limitation of their design, they suggest, was because: "feedback loops were not included" (1984:327). Steers and Mowday suggested that: "feedback loops may be important to an understanding of commitment and the turnover process" (1981:15).

When commitment and satisfaction are studied over time, the impact of organisational, social and cultural conditions can be assessed. The fact that extra-organisational influences may be continually operating to change one's dtgree of commitment or satisfaction, means that findings valid, at one point in 
time, may not be so at another. This raises the question of predictability. The present study measured commitment and satisfaction of a sample of individuals at a point in time. The degree of satisfaction and commitment cannot be predicted for a later period of time even for the same sample. The research was exploratory in nature, designed specifically to test a model of turnover intentions. Any attempt to predict or generalise intentions to leave from the results of this study would seriously violate the assumptions of empirical research. It does, however, provide a microscopic look at a segment, albeit small, of the Navy. The findings, if only for the reason that they, in part, contradicted the literature, are not insignificant in themselves and merit further investigation.

Another limitation to the stud:" of commitment, in particular, is the concept of multiple commitments. Commitment to one institution does not preclude, necessarily, commitment to others. A study by Americ and Aranya for example, investigated the professional and organisational commitment of chartered accountants. They found that there is a conflicting demand of professional and organisational commitment. Accordingly, "the less the professional organisational conflict, the higher the correlation between professional and organisational commitment" (1983:337). Consequently, as long as the two are congruent, there is high organisational commitment. However, they contend that professional commitment will take precedence over organisational commitment when the two are not compatible. Navy engineers (MARE - Maritime 
engineering) for example, view themselves, like doctors and lawyers, as 'professionals'. Thus, they may be simultaneously committed to the profession of engineering, as well as to the military profession but not necessarily to the detriment of either.

The present research found and discussed the family institution as a "greedy" one, competing for an individual's commitment with that to the Navy. This does not, however, make his/her commitment to the Navy any less. Segal contends: "the study of military families involves analysis of how two societal institutions, the military and the family, intersect...The way in which they respond to this competition for the service member's commitment are already affecting how far the military moves in an institutional or occupational direction" (1986:34). Thus, if the Navy is willing to concede and adapt to the modern reality of the importance of family concerns to its members, it, ironically, may be encouraging rather than lessening commitment.

Consequently, having many commitments is not a zero sum game. Rather multiple commitments may serve to enhance and reinforce one another. The difficulty for research is in evaluating the multiple commitment phenomenon and its effect on one's degree of commitment to organisations such as the Navy. It is necessary, therefore, to redefine the concept of commitment to encompass a more global, comprehensive perspective. This approach may: "...be more closely 
aligned to individual's actual experience...and may serve to differentiate commitment more fully from related constructs" (Reichers 1985:474). These conceptual issues similarly apply to the concept of satisfaction. Satisfaction is also multi-faceted, ever changing, and influenced continually by the organisational environment.

The importance of individual perceptions to the organisational environment cannot be overemphasised in the study of commitment and satisfaction. This study raised the question of how does one measure the individual's cognitive assessment of his/her organisational climate? The problem of individual differences may explain, in part, why only some support was found for the turnover intentions model proposed. Locke contended that: "...An individual's evaluation of an object or situation will be a function of the perceived relationship between what he perceives and what he values" (1969:319). Commitment to, and satisfaction with, the Navy are perceived and assessed by each individual member differently.

This evaluation is an inherent part of any model of turr.over intentions which is difficult, if not impossible, to measure. Consequently, there is a considerable amount of dynamics within the commitment/satisfaction process and in process of turnover behaviour which cannot be accounted for and may, at most, be only inferred. In this study, only $30 \%$ of the variance in turnover intentions 
was explained. This leaves much unaccounted for. A more comprehensive, detailed model of turnover intentions appears to be required to capture the full complexity of the dynamics of leaving behaviour.

Another limitation is that littie is known of the philosophical basis of commitment. This aspect of commitment though recognized is immeasurable and not subject to scientific enquiry. It is a dimension that cannot be ignored, however, when the concept is studied in detail and must be taken into consideration when results of any study are interpreted. Individual commitment is different in pease time armies than it is in times of war. Perhaps the only time that military commitment can be evaluated is in times of crisis. Cotton (1980), for example, contends that there is another dimension to commitment that is not subject to scientific enquiry - moral commitment. As a consequence, some have argued for the phenomenological approach in the study of commitment. This research involved a sample of Naval personnel employed at the Navy training schools, static units. An interesting comparison would be to conduct similar research on more operational units - and more when these units are engaged in military conflict, such as the recent war in the Persian Gulf. 


\section{Measurement issues}

As a consequence of design limitations, measurement instruments used in commitment research have been one-dimensional. That is, most studies have used the Organisation Commitment Questionnaire (OCQ) developed by Mowday, Steers and Porter (1979) primarily because of its statistically proven psychometric properties. The difficulty is that the scale measures attitudinal commitment and only infers behavioural commitment through the resultant outcomes. Meyer and Allen (1984) were two of the few researchers who used scales which tested both the attitudinal and behavioural dimensions of commitment.

This $\therefore$ used three measures of organisational commitment, the OCQ; ail. ay Liros Sule ' itS); and a question regarding Forced Choice. All, … ie morsurs of attitudes. Studies involving more than one measure providi.. Fr 1 mort interactive approach, would lend further credence to the construet " tliosty of the concept.

The Job Descriptive Index (JDI) is also a measure of the affective component of job satisfaction. The concept of satisfaction is, in itself, difficult to measure. As Locke contended: "intensity of satisfaction and value importance cannot be measured in terms of any known physical or psychological units" (1969:331). What then has the JDI measured in this study? The fact that only two 
of the six scales of this index had any relevancy, together with the fact that the scales were not designed for the 'peculiarities' of military terminology, suggest that the JDI was not a particularly appropriate measure to use in this type of study. In a Idition, there were no normative scales provided for a comparable population.

There is no doubt that the study of organisational commitment and job satisfaction is complex and that the understanding of these concepts is far from complete or comprehensive as one would like it to be. Empirical research, including the present study, has generated more questions than it has answered.

\section{3 - Implications for future research}

Given the methodological and measurement limitations discussed for the study, as well as the findings which resulted, there are several implications for future research. These are:

(1) the requirement to develop and test a comprehensive model of turnover behaviour which encompasses cyclical rather than linear relationships. A proposed model would be as follows: 


\section{Figure 18}

\section{Suggested Model of Turnover Intentions}

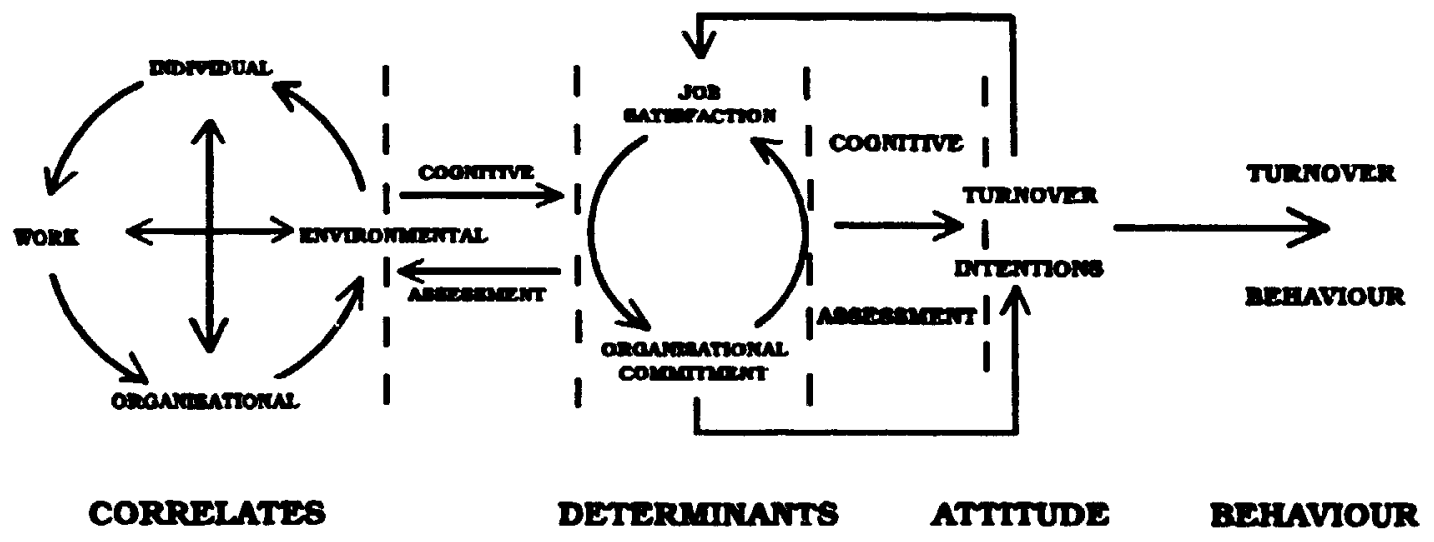

It is not difficult to understand why linear models are preferable to reciprocal or cyclical. They are more conducive to scientific investigation and testing since they are more simplistic and parsimonious in their approach.

(2) the requirement to develop valid instruments to measure not only the attitudinal but also the behavioural components of commitment and satisfaction.

(3) the requirement to use a lcngitudinal research design and sample a cohort of new Naval entries both at the Officer and Non-commissioned member level; test job satisfaction and commitment at significant career stages; and follow up by examining the actual attrition of the particular cohorts - that is, an attrition study. Research similar to the Atkinson Foundation study of Ontario high school students in the 1950's would be most useful.

(4) the requirement to compare measures of commitment and satisfaction among operational and static Naval units with the aim to developing normative scales for future research. 
(5) a demographic factor not undertaken in this research was ethnic background, particularly French and English Canadians. Though little empirical evidence exists, there is a possible distinction/difference in the way Anglophones and Francophones view the work ethic. This may be particularly true within a military environment. This is an area of study which merits further consideration.

\section{4 - Policy implications}

Two of the major findings in this research were: (1) that Officers were the most likely to have intentions to leave the Navy; and, (2) they were the least satisfied with their promotional prospects in the Navy.

Promotion in a military context is an extremely important criterion for most of its members. Not only does it signify a recognition and reward for one's ability and skills, but it also connotes an expansion of responsibilities and increased job challenge. Although rank (status) is an integral part of any organisation, it is particularly so in a military context because one's status is more salient, visible and recognisable by all - it is worn as a badge on the uniform. Promotion, while a universal expectation of all who work in organisations, seems to play a singularly important role in the military. Not only does it manifest itself in the form of increased salary, benefits, responsibilities and privileges but it becomes a visible declaration of one's worth to the organisation. It is not surprising, therefore, that if naval personnel enter the organisation with positive attitudes and high expectations which are not realised and find themselves with negative attitudes 
and unfulfilled goals of promotion, they will be likely to express intentions to leave the Navy rather than stay.

Jans (1989) suggested that there were four career stages.

(1) apprenticeship; (2) development; (3) establishment; and, (4) maintenance. Thus, one's career progresses from initial training to effective employment on the job to establishing professional expertise and recognition and finally, if selected, $t)$ further advancement or if not, to maintaining one's status and employment. Upward mobility is important in each of these stages.

The Navy, however, is a highly structured, pyramidal, hierarchical organis ation where opportunities for advancement become increasingly limited. There are less opportunities for promotion at the higher ranks than at the lower ones. The result is that not everyone's expectation for promotion will be met, many members will become 'cemented' within a particular career stage.

Consequently, what is required are incentives, other than promotion, to prevent highly trained, productive personnel from leaving the Navy. One method would be to develop lateral promotion or an expansion of skills which would allow members to increase their range of ability and responsibility and, yet, at the same time provide job challenge. This would serve to maintain motivation, particularly, for those at the mid-career stage. A Trade Advancement for Skill and Knowledge 
(TASK) program is presently being designed for Non-commissioned members. What is needed is a similar program for Officers.

The Navy and the military, in general, must develop policies, particularly in recruitment, which stress the goals of realistic expectations. Not everyone is going to become a General, an Admial, fly fighter aircraft or command a ship. Training and advancement occurs only through a highly selective and competitive merit system. Selling the organisation realistically at the beginning will prevent higher turnover later.

It has only been in the recent past that the Navy has adopted initiatives to recognise the important role the family plays in an individual's career. Establishing Family Support Centers and increasing tour lengths are wholesome steps. These and others must be continued and improved upon. The congruency between the two "greedy" institutions of military and family is a necessary precondition to promoting commitment and satisfaction.

\section{5 - Conclusion}

This research has been conducted on a very small sample of navy personnel. Its findings cannot be generalised to other naval units or for that matter, other military units. It is but a microscepic look at a small microcosm of a large military organisation. The results, however, are interesting in that they point 
to possible 'danger' areas in terms of the loss of well trained, highly skilled, and productive personnel. The cost of turnover is expensive.

Conversations with Navy personnel during the conduct of this research reflected feelings of discontent, frustration and anger. Never did they ever express feelings of disloyalty. They were dedicated in their duty and professiolsal in their approach. The problem, therefore, lies not with its members but with the crganisation itself. The military is an integral part of Canadian society; its role is socially determined and its organisation is socially responsive to the surrounding social milieu. As a consequence, however, the role of the military as a distinct institution has become obscured. As Gabriel contends: "it (the military) began to lose the perception of itself as a true profession...distinguished from a business enterprise by the scope of its service to society" (1985:195).

Given the enormous changes that the Navy has undergone which would strained the morale of any crganisation, it seems, ironically, that it is the commitment, motivation and loyalty of its members which are the main factors holding it together.

Except in wars too remote for most to remember, Canadians have given little time, small treasure and less respect to their seaman-at-arms. But remarkable fact remains: in war and peace the people in Canada's Navy have served this country steadfastly and, quite astonishingly very, very well. Their commitment has found no limits to the challenge of the sea. And simply, you will find no better sailors in the world than these (German 1990:326). 


\section{REFERENCES}

Alutto, J.A., Hrebiniak, LG., and Alonso, R.C. (1973). On operationalizing the concept of commitment. Social Forces, Vol. 51, 448-453.

Amernic, J.H. and Aranya, N. (1983). Organizational commitment: testing two theories. Relations Industrielles, Vol. 38, No. 2, 319-339.

Anderson, J.C. and Milkovich, G.T. (1980). Propensity to leave: a preliminary examination of March and Simon's model. Relations Industrielles, Vol. 35, No. 2, 279-291.

Angle, H.L and Perry, J.L. (1981). An empirical assessment of organizational commitment and organizational effectiveness. Administrative Science Quarterly, Vol. 26, 1-13.

Arnold, Hugh J. and Feldman, Daniel C. (1982). A multivariate analysis of the determinants of job turnover. Journal of Applied Psychology, Vol. 67, No. 3, 350-360.

Baba, V. and Jamal, M. (1979). On Becker's theory of commitment: an empirical verification among blue collar workers. Relations Industrielles, Vol. 34, No. 1, 123-136.

Baba, V. and Jamal, M. (1977). Company satisfaction, company commitment and work involvement: an empirical examination of blue collar workers. Relations Industrielles, Vol. 31, No. 3, 435-445.

Baba, V. and Knoop, R. (1987). Organizational commitment and injependence among Canadian managers. Relations Industrielles, Vol. 42, No. 2, 325-341.

Barth, Richard T. (1968). Organizational commitment and identification of engineers as a function of organizational climate. Relations Industrielles, Vol. 29, No. 1, 185-199.

Bateman, Thomas S. and Strasser, Stephen. (1984). A longitudinal analysis of the antecedents of organisational commitment. Academy of Management Journal, Vol. 27, No. 1, 95-112.

Bateman, Thomas S. and Griffin, Ricky W. Job satisfaction and organisational commitment. Technical Report No. 16, Office of Naval Research, Arlington, VA, 1985. 
Becker, H.S. (1960). Notes on the concept of commitment. American Journal of Sociology, 66, 32-40.

Blau, Gary J. and Boal, Kimberly B. (1987). Conceptualizing how job involvement and organizational commitment affect turnover and absenteeism. Academy of Management Review, Vol. 12, No. 2, 288-300.

Bluedorn, Allen C. (1979). Structure, environment and satisfaction: Toward a causal model of turngver from military organisations. Journal of Militiry and Political Sociology, Vol. 7, 181-207.

Bradley, J.P. and Paunonen, S.V. (1989). The Determinants of Medical Officers' Intentions to Leave the Canadian Forces. (Working Paper 89-4). Willowdale, Ontario: Canadian Forces Personnel Applied Research Unit.

Brooke, Paul P. Jr. and Russell, D.R. (1988). Discriminant validation of measures of job satisfaction, job involvement and organizational commitment. Journal of Applied Psychology, Vol. 73, No. 2, 139-145.

Buchanan, B.H. (1974). Building organisational commitment: The socialisation of managers in work organisations. Administrative Science Quarterly, 19, 533-546.

Caforio, Guiseppe. (1988). The military profession: Theories of change. Armed Forces and Society, Vol. 15, No. 1, 55-69.

Canadian Forces Personnel Newsletter 11/90. Office of the Assistant Deputy Minister (Personnel), National Defence Headquarters, Ottawa, Ontario. 1990.

Cooper, R. and Payne, R. (1965). Age and absence: A longitudinal study in three firms. Occupational Psychology, 39, 31-43.

Coser, Lewis A. Greedy Institutions: Patterns of Undivided Commitment. New York: The Free Press. 1974.

Cotton, C.A.U. The Divided Army: Role Orientations Among Canada's Peacetime Soldiers. Unpublished PhD thesis. Carleton University. 1980.

Curry, James P., Wakefield, D.S., Price, J.L and Mueller, C.W. (1986). On the causal ordering of job satisfaction and organizational commitment. Academy of Management Journal, Vol. 29, No. 4, 847-858. 
Department of National Defence Statistical Summary, DPIS Y9012006 National Defence Headquarters, Ottawa, Ontario. 1990.

Dubin, Robert, Champoux, J.E and Porter, L.W. (1975). Central life interests and organizational commitment of blue collar and clerical workers. Administrative Science Quarterly, Vol. 20, 411-421.

Etzioni, Amitai. Modern Organisations. New Jersey: Prentice-Hall. 1961.

Farkas, Arthur J. and Tetrick, Lois E. (1989). A three-wave longitudinal analysis of the causal ordering of satisfaction and commitment on turnover decisions. Journal of Applied Psychology, Vol. 74, No. 6, 855-868.

Ferris, Kenneth R. and Aranya, Nissim. (1983). A comparison of two organisational commitment scales. Personnel Psychology, 36, 87-97.

Gabriel, Richard A Military Incompetence: Why the American military doesn't win. New York: Hill and Wang. 1985.

German, Commander Tony. The Sea is at Our Gates: The History of the Canadian Navy. Toronto: McClelland and Stewart Inc. 1990.

Glisson, Charles and Durick, Mark. (1988). Predictors of job satisfaction and organizational commitment in human service organizations. Administrative Quarterly, Vol. 33, 61-81.

Goffman, Erving. Asylums: Essays on the Social Situation of Mental Patients and Other Inmates. New York: Doubleday and Company. 1961.

Graen, George B. and Hulin, Charles L. (1968). Addendum to empirical investigation of two implications of the two factor theory of job satisfaction. Journal of Applied Psychology, Vol. 52, No. 4, 341-342.

Grusky, Oscar. (1966) Career mobility and organisational commitment. Administrative Science Quarterly, 10, 488-503.

Grusky, Oscar. (1965). Career mobility and organizational commitment. Administrative Science Quarterly, Vol. 10, 488-503.

Hackett, Sir John. The Military in the Service of the State. In War, Morality and the Military Profession. M.W. Boulder (ed.). London: Westview Press. 1979. 
Hall, Douglas T. and Schneider, Benjamin. (1972). Correlates of organizational identification as a function of career pattern and organizational type. Administrative Science Quarterly, Vol. 17, 340-350.

Hrebiniak, Lawrence G. and Alutto, Joseph A (1972) Personal and role related factors in the development of organizational commitment. Administrative Science Quarterly, Vol. 17, 555-573.

Hulin, Charles L and Smith, Patricia A. (1967). Implications of the two factor theory of job satisfaction. Journal of Applied Psychology, Vol. 51, No. 5, 396-402.

Hunt, John W. and Saul, Peter N. (1975). The relationship of age, tenure and job satisfaction in males and females. Academy of Management Journal, Vol. 18. No. 4, 690-701.

Janowitz, Morris. (1977). From institutional to occupational: the need for conceptual continuity. Armed Forces and Society, Vol. 4, No. 1, 51-54.

Jans, N.A. (1989). Organizational commitment, career factors and career/life stage. Journal of Organizational Behaviour, Vol. 10, 247-266.

Kahn, R.L, Wolfe, D.M., Quinn, R.P., Snoek, J.D. and Rosenthal, R.A. Organisationai Stress: Studies in Role Conflict and Ambiquity. New York: Wiley. 1964.

Kalleberg, Arne L (1977). Work values and job rewards: A theory of job satisfaction. American Sociological Review, Vol. 42, 124-143.

Kanter, Rosabeth Moss. (1968). Commitment and social organization: a study of commitment mechanisms in utopian communities. American Sociological Review, Vol. 33, No. 4, 499-517.

Katzell, M.E. (1968). Expectations and dropouts in schools of nursing. Journal of Applied Psychology, 52, 154-157.

Koch, James L and Steers, Richard M. (1978). Job attachment, satisfaction and turnover among public sector employees. Journal of Vocationai Behaviour, Vol. 12, 119-128.

Lachman, Ran and Aranya, Nissim. (1986). Job attitudes and turnover intentions. Organisation Studies, 7/3, 279-293. 
Lincoln, James R., Hamada, Mitsuyo and Olsen, Jon. (1981). Cultural orientations and individual reactions to organizations: a study of employees of Japanese-owned firms. Administrative Science Quarterly, Vol. 26, 93-114.

Locke, Edwin A. (1969). What is job satisfaction? Organizational Behaviour and Human Performance, Vol. 4, 309-336.

Luthans, Fred, McCaul, Harriette S. and Dodd, Nancy G. (1985). Organizational commitment: A comparison of American, Japanese and Korean employees. Academy of Management Joumal, Vol. 28, No. 1, 213-219.

Maillet, L (1987). The socialization of CMR Officer Cadets: descriptive statistics. (Working Paper 87-1). Quebec: College Militaire Royale de Saint-Jean.

Marsh Robert, M. and Manrari, Hiroshi (1977). Organizational commitment and turnover: a prediction study. Administrative Science Quarterly, Vol. 22, 57-75.

Martin, Thomas N. (1979). A contextual model of turnover intentions. Academy of Management Journal, Vol. 22, No. 2, 313-324.

Martin, Thomas, N. (1989). A contextual model of employee turnover intentions. Academy of Management Joumal, Vol. 22, No. 2, 313-324.

McDonald, Blair W. and Gunderson, Eric. (1973). Correlates of job satisfaction in Naval environments. Journal of Applied Psychology, Vol. 58, 371-373.

McGee Gail W. and Ford, Robert C. (1987). Two (or more?) dimensions of organizational commitment: re-examination of the affective and continuance commitment scales. Journal of Applied Psychology, Vol. 72, No. $4,638-642$.

Mendes, H.C. and Lyon, C.D.F. (1984). Canadian Forces attrition/retention study. (Working Paper 84-8). Willowdale, Ontario: Canadian Forces Personnel Applied Research Unit.

Meyer, John P., Paunonen, S.V., Gellaty, I.R., Goffin, R.D. and Jackson, Douglas N. (1989). Organizational commitment and job peiformance: it's the nature of the commitment that counts. Journal of Applied Psychology, Vol. 74, No. 1, 152-156. 
Michaels, Charles E. and Spector, Paul E. (1982). Causes of employee turnover: A test of the Mobley, Griffeth, Hand and Meglino model. Journal of Applied Psychology, Vol. 67, No. 1, 53-59.

Mobley, William H., Horner, Stanley, O. and Hollingsworth, A.T. (1978). An evaluation of precursors of hospital employee turnover. Journal of Applied Psychology, Vol. 63, No. 4, 408-414.

Mobley, William H. (1977). Intermediate linkages in the relation between joh satisfaction and employee turnover. Journal of Applied Psychology,

Vol. 62, No. 2, 237-240.

Mobley, W.H., Griffeth, R.W., Hand, H.H. and Meglino, B.M. (1979). Review and conceptual analysis of the employee turnover process. Psychological Bulletin, Vol. 86, No. 3, 493-522.

Morrow, P.C. (1983). Concept redundancy in organisational research: The case of work commitment. Academy of Management Keview, 8, 486-500.

Moskos, Charles C. Institutional/ occupational trends in the Armed Forces: an update. Armed Forces and Society, Vol. 12, No. 3, 377-382.

Moskos, Charles C. (1977). From institution to occupation: trends in military organization. Armed Forces and Society, Vol. 4, No. 1, 41-50.

Motowidlo, Stephan J. and Borman, Walter C. (1978). Relationships between military morale, motivation, satisfaction and unit effectiveness. Journal of Applied Psychology, Vol. 63. No. 1, 47-52

Mowday, Richard T., Steers, Richard M. and Porter, Lyman W. Toward a theory of organisational commitment. Technical Report No. 8, Office of Naval Research, Arlington, VA, 1981.

Mowday, Richard T., Steers, Richard M. and Porter, Lyman W. The Consequences of Employee Commitment. Turnover and Absenteeism: An Exploratory Analysis. Technical Report No. 9, Office of Naval Research, Arlington, VA, 1981.

Mowday, R.T., Koberg, C.S. and McArthur, AW. (1984). The psychology of the withdrawal process: A cross-validational test of Mobley's intermediate linkages model of turnover in two samples. Academy of Management Journal, Vol. 27, No. 1, 79-94. 
Mowday, Richard T., Steers Richard M. and Porter, Lyman W. (1979). The measurement of organizational commitment. Journal of Vocational Behaviour, Vol. 14, 224-247.

Muchinsky, Paul. M. and Tuttle, Mark L (1979). Employee turnover: An empirical and methodological assessment. Journal of Vocational behaviour, Vol. 14, 43-77.

Near, Janet, P. (1989). Organisational commitment among Japanese and U.S. workers. Qrganisation Studies, Vol. 10, No. 3, 281-300.

Norusis, Marija J. Statistical Package for the Social Sciences/PC Base Manual. New York: McGraw-Hill, 1988.

Oliver, Nick. (1990). Rewards, investments, altematives and organisational commitment: Empirical evidence and theoretical development. Journal of Occupational Psychology, Vol. 63, 19-31.

Parker, R.O. and Lyon, C.D.F. (1988). Preliminary evaluation of the Canadian Forces attrition information questionnaire. (Technical Note 20/88). Willowdale, Ontario: Canadian Forces Personnel Applied Research Unit.

Pedhazur, Elazar J. Multiple Regression in Behavioral Research (second edition). New York: Holt, Rinehart and Winston, 1982.

Porter, Lyman W., Crampon, William J. and Smith, Frank J. (1976). Organizational commitment and managerial turnover: a longitudinal study. Organizational Behaviour and Human Performance, Vol. 15, 87-98.

Porter, Lyman W., Steers, Richard M. and Mowday, Richard T. (1974). Organizational commitment, job satisfaction and turnover among psychiatric technicians. Journal of Applied Psychology, Vol. 59, No. 5, 603-609.

Porter, Lyman W. and Steers, Richard M. (1973). Organisational, work and personal factors in employee turnover and absenteeism. Psychological Bulletin, Vol. 80, No. 2, 151-176.

Price, James L The Study of Turnover. Iowa: the Iowa State University Press. 1977.

Reichers, Amon E. (1986). Conflict and organisational commitments. Joumal of Applied Psychology, Vol. 71, No. 3, 508-514. 
Reichers, Arnon E. (1985). A review and reconceptualization of organizational commitment. Academy of Management Review, Vol. 10, No. 3, 465-476.

Roznowski, Mary. (1989). Examination of the measurement properties of the job descriptive index with experimental items. Journal of Applied Psychology. Vol. 74, No. 5, 805-814.

Rusbult, Caryl E. and Farrell, Dan. (1983). A longitudinal test of the investment model: The impact on job satisfaction, job commitment and turnover variations in rewards, costs, alternatives and investments. Journal of Applied Psychology, Vol. 68, No. 3, 429-438.

Salancik, G.R. Commitment and the Control of Organisational Behaviour and Belief. In B.M. Staw and G.R. Salancik (eds.). New Directions in Organisational Behaviour. Chicago: St. Clair Press. 1977.

Segal, D.R. (1986). Measuring the institutional/occupational change thesis. Administrative Science Quarterly, 12, 351-376.

Segal, Mady Wechsler. (1986). The military and the family as greedy institutions. Armed Forces and Society, Vol. 13, No. 1, 9-38.

Sheldon, Mary E. (1971). Investments and involvements as mechanisms producing commitment in the organization. Administrative Science Quarterly, Vol. 16, 143-150.

Smith, P.C., Kendall, LM. and Hulin, C.C. The Measurement of Satisfaction in Work and Retirement: A Strategy for the Study of Attitudes. New York: Rand McNally and Company. 1975.

Stahl, Michael J., McNichols, C.W. and Manley, T.R. (1977). An empirical examination of the Moskos institution - occupation model. Armed Forces and Society, Vol. 4, No. 1, 257-269.

Stahi, Michael J., Manley, T. Roger and McNichols, Charles W. (1978). Operationalizing the Moskos institution - occupation model: an application of Gouldner's cosmopolitan - local research. Journal of Applied Psychology, Vol. 63, No. 4, 422-427.

Steers, Richard M. and Rhodes, Susan R. Major influences in employee attendance: A process model. Journal of Applied Psychology, Vol. 63, No. 4, 391-407. 
Steers, Richard M. (1977). Antecedents and outcomes of organizational commitment. Administrative Science Quarterly, Vol. 22, 46-56.

Steers, Richard M., Mowday Richard T. and Porter, Lyman W. Commitment Careers and Retention in Organisations: A Final Report. Technical Report No. 23, Office of Naval Research, Arlington, VA., 1985.

Stevens, John M., Beyer Janice M. and Trice, Harrison M. (1978). Assessing personal, role and organizational predictors of managerial commitment. Academy of Management Joumal, Vol. 21, No. 3, 380-396.

Stumpf, Stephen A. and Hartman, Karen. (1984). Individual exploration to organizational commitment or withdrawal. Academy of Management Journal, Vol. 27, No. 2, 308-329.

Taylor, Kenneth E. and Weiss, David J. (1972). Prediction of job termination from measured job satisfaction and biographical data. Journal of Vocational Behaviour, Vol. 2, 123-132.

Weber, W.L, Marshall, J.J. and Haines, G.H. (1986). Modelling commitment and its antecedents. Canadian Journal of Administrative Sciences, Vol. 6, No. 3, 12-23.

Wiener, Yoash and Vardi, Yoav. (1980). Relationships between job, organization and career commitments and work outcomes - an integrative approach. Organizational Behaviour and Human Performance, Vol. 26, 81-96.

Williams, Larry J. and Hazer, John T. (1986). Antecedents and consequences of satisfaction and commitment in turnover models: A reanalysis using latent variable structural equation methods. Journal of Applied Psychology, Vol. 71, No. 2, 219-231.

Youngblood, Stuart A, Mobley, William H. and Meglino, Bruce M. (1983). A longitudinal analysis of the turnover process. Journal of Applied Psychology, Vol. 68, No. 4, 507-516.

Zaccaro, Stephen J. and Dobbins, Gregory H. (1989) Contrasting group and organizational commitment: evidence for differences among multilevel attachments. Journal of Organizational Behaviour, Vol. 10, 267-273. 


\section{QUESTIONNAIRE SURVEY?}

The purpose of this questionnaire is to obtain a standardised assessment of how members of the Canadian Navy feel about their career.

All data from this study will be treated in the strictest confidence so that your individual responses will not be made available to any other person or agency. your responses will be converted into group information and will provide only summary findings to $\mathrm{Cr}$ agencies on request.

Your voluntary cooperation in this project is essential for its success and is greatly appreciated.

2 Sources: 2. Organisational Commitment Questionnaire by Mowday, Richard T., Steers, Richard M. and Porter, Lyman W. 1979.

b. Job Descriptive Index by Smith, P.C., Kendall, L and Hulin, C.L 1975.

c. Military Ethos Scale by Cotton, C.A.U. 1979.

d. Canadian Forces Medical Officer Questionnaire by Bradley, J.P. and Paunonen, S.V. 1989. 


\section{PART A}

INSTRUCDONS - Listed below are a series of statements which represent possible feelings that people might have about the Navy. With respect to your own feelings towards the Navy, please indicate the degree of your agreement or disagreement with each statement by circling one of the five alternatives. If you don't know, indicate by putting a check mark in the appropriate space.

1. I am willing to put a great deal of effort beyond that normally expected of me in order to help the Navy be successful.
(1) strongly disagree
(2) disagree
(3) neither agree nor disagree
(4) agree
(5) strongly agree
don't know

2. I talk up the Navy to my friends as a great organisation to work for.
(1) strongly disagree
(2) disagree
(3) ncither agree nor disagree
(4) agree
(5) strongly agree
don't know

3. I feel a great deal of loyalty to the Navy.
(1) strongly disagree
(2) disagree
(3) neither agree nor disagree
(4) agree
(5) strongly agree
don't know

4. I would accept any type of position in order to remain in the Navy.
(1) strongly disagree
(2) disagree
(3) neither agree nor disagree
(4) agree
(5) strongly agree
don't know

5. I find that my values and those of the Navy are very similar.
(1) strongly disagree
(2) disagree
(3) neitber agres nor disagree
(4) agree
(5) strongly agree
don't know 
6. I am proud to tell others that I am in the Navy.
(1) strongly disagree
(2) disagree
(3) neither agree nor disaggre
(4) agree
(5) strongly agrce
don't know

7. I could just as well work for a different organisation as long as the type of work wals similar.
(1) strongly disagree
(2) disagree
(3) neither agree nor disagrec
(4) agrec
(5) strongly agree
don't know

8. The Navy really inspires the very best in me in the way of job performance.
(1) strongly disagree
(2) disagree
(3) neither agree nor disagree
(4) agree
(5) strongly agree
don't know:

9. It would take a lot to make me leave the Navy.
(1) strongly disagree
(2) disagree
(3) neither agree nor disagree
(4) agree
(5) strongly agree
don't know

10. I am very glad that I che e the Navy rather than the Army, Air Force or civilian organisations I was considering at the time I joined.
(1) strongly disagree
(2) disagree
(3) neither agree nor disagree
(4) agree
(5) strongly agree
don't know

11. There's a great deal to be gaincd by staying in the Navy indefinitely.
(1) strongly disagree
(2) disagree
(3) neither agree nor disagree
(4) agree
(5) strongly agree
don't know 
12. Often, I find it easy to agree with the Navy's policies on important matters related to its personnel and objectives.
(1) strongly disagree
(2) disagree
(3) neither agree nor disagree
(4) agree
(5) strongly agree
don't know

13. I really care about the future of the Navy.
(1) strongly disagree
(2) disagree
(3) neither agree nor disagree
(4) agree
(5) strongly agree
don't know

14. For me, the Nayy is the best of all possible organizations for which to work.

(1) strongly disagree

(4) agree

15. Deciding to join the Navy was a definite mistake on my part.

(1) strongly disagree

(2) disagree

(4) agree

(5) strongly agree

16. I should accept only the postings that I want.
(1) strongly disagree
(2) disagree
(3) neither agree nor disagree
(4) agree
(5) strongly agree
don't know

17. What a member of the Navy does in his or ber off-duty hours is nune of the military's business.
(1) strongly disagree
(2) disagree
(3) neither agree nor disagree
(4) agree
(5) strongly agree
don't know

18. Naval personnel should perform their operational duties regardless of their personal and family obligations.
(1) strongly disagree
(2) disagree
(3) neither agree nor disagree
(4) agree
(5) strongly agree
don't know 
19. Differences in rank should be important even after duty hours.
(1) strongly disagree
(2) disagree
(3) neither agree nor disagree
(4) agree
(5) strongly agree
don't know

20. What a member does in his/her private life should be of no concern to his/her supervisor or commander.
(1) strongly disagree
(2) disagree
(3) neither agree nor disagree
(4) agree
(5) strongly agree
don't know

21. Personal interests and wishes must take second place to operational requirements for Naval personnel.
(1) strongly disagree
(2) disagrce
(3) neither agree nor disagree
(4) agree
(5) strongly agree
don't know

\section{PART B}

INSTRUCTIONS- The following question pertains to your Naval career in general. Think of your career. What is it like most of the time? In the blank beside each word writc "Y" for "yes", if it describes your life in the Navy. Write "N" for "no" if it does not describe it. Write "?" if you cannot decide.

\section{OVERALL}

Pleasant

Bad
Ideal
Waste of time
Good
Undesirable
Worthwhile
Worse than most carcers
Acceptable


Like to leave

Better than most careers

Disagreeable

Makes me content

Inadequate

Excellent

Rotten

Enjoyable

Poor

INSTRUCTIONS - Indicate whether each word or phrase below applies, in general, to your present position. In the blank space beside each word or phrase write "Y" for "yes" if it describes your position. If the word does not describe your position write " $\mathrm{N}$ " for "no". Write "?" if you cannot decide.

POSITION

Fascinating

Routine

- Satisfying

Boring

Good

Creative

_ Respected

Hot

Pleasant

Useful 


Tiresome
Healthful
Challenging
$\ldots \quad$ On your feet
$\ldots \quad$ Frustrating
Simple
Endless

INSTRUCTIONS - Think of the opportunities for promotion within your own trade or classification. How does each iter below describe these promotion opportunities? Write "Y" if it describes your situation. Write "N" if it does not describe it. Writc "'?" if you cannot decide.

PROMOTICINS __ Good opportunity for advancement

_ Opportunity somewhat limited

Promotion based on ability

Dead-end job

Good chance for promotion

__ Unfair promotion policy

Infrequent promotions

Regular promotions

_ Fairly good chance for promotion 
INSTRUCTIONS - Think of the pay and benefits you receive from the CF. How well does each item below describe your pay and benefits? In the blank beside each word write " $\mathrm{Y}$ " if it $\mathrm{d}$ zscribes yc ur pay and benefits. Write " $\mathrm{N}$ " if it does not describe your pay and benefits. Write "?" if you cannot decide.

PAY AND BENEFITS Income adequate for normal expenses

Satisfactory pension/benefi
Barely living un income
Bad
Income provides luxuries
Insecure
Less than I deserve
Highly paid
Underpaid

INSTRUCTIONS - Think of your co-workers in your unit. What are they like most of the time? How well does each of these words describe them? In the blank beside each word write " $Y$ " if it describes your co-workers. Write " $N$ " if it does not describe them. Write "?" if you cannot decide.

WORKERS

$\ldots$ Stimulating
$\ldots$ Boring
Slow
$\ldots$ Ambitious
$\ldots$ Stupid
$\ldots$ Responsible
$\ldots$ Fast




Intelligent
Easy to make enemies with
Talk too much
Smart
Laxy
Unpleasant
No privacy
Active
Narrow interests
Loyal
Hard to mect

INSTRUCTIONS - Trink of your current supervisor, the one who has the most influence on the things you do in your present position. What is the person like most of the time"? In the blanks below put " $\mathrm{Y}$ " if it describes your supervisor. Put " $N$ " if it does not describe him/her. Put "?" if you cannot decide.

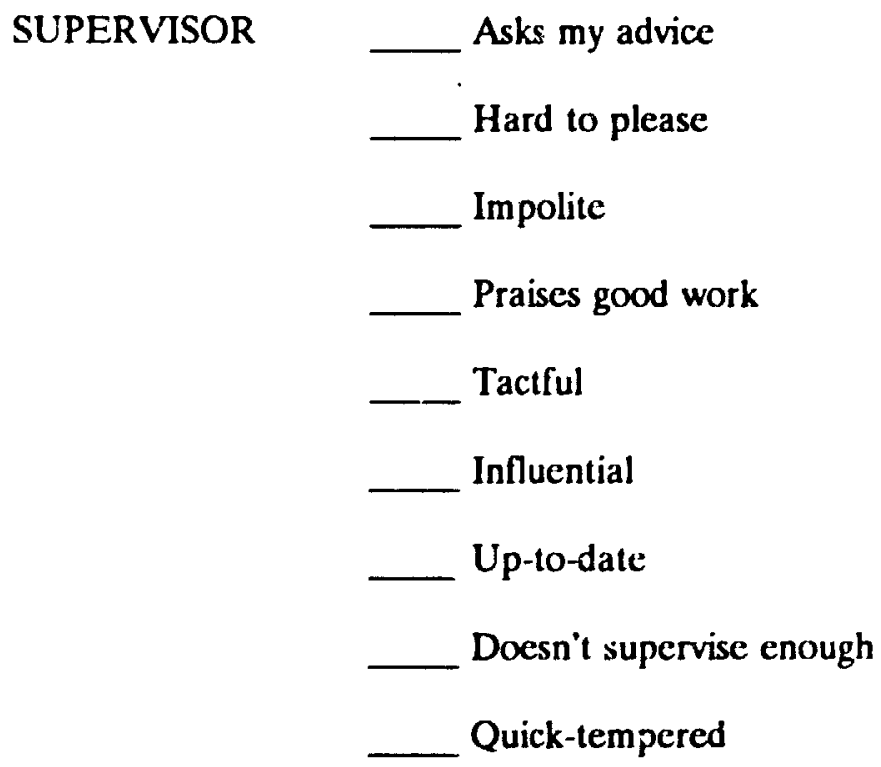


Tells me where I stand

Annoying
Stubborn
Knows job well
Bad
Intelligent
Leaves me on my own
Around when nceded
Lazy

\section{PART C}

INSTRUCTIONS. Consider that you have two general career options: remaining in the Navy or leaving the Navy. The following questions pertain to the corsequences to you of remaining in the Navy. It is understood that you may be serving under obligatory service and must remain in the Navy for that period even though you would rather leave. Nevertheless, please complete the questions, by circling one of the five alternatives, as if you were currently free to leave or stay. If you don't know, indicate by putting a check mark in the appropriate space.

\section{I believe that remaining in the Navy will result in my....}

1. ...having more control over the type of work 1 do
(1) extremely unlikely
(2) unlikely
(3) undecided
(4) likely
(5) extremely likely
don't know

2. ...having more control over the scheduling of my work.
(1) extremely unlikely
(2) unlikely
(3) undecided
(4) likely
(5) extremely likely
don't know 


\section{I believe that remaining in the Navy will result in my....}

3. ...having more control over where (geographical location) I work.
(1) extremely unlikely
(2) unlikely
(3) undecided
(4) likely
(5) extremely likely
don't know

4. ...being engaged in work that permits me to maintain my professional/technicial shills.
(1) extremely unlikely
(2) unlikely
(3) undecided
(4) likcly
(5) extremely likely
don't know

5. ...having better pension benefits.
(1) extremely unlikely
(2) unlikely
(3) undecided
(4) likely
(5) extremely likely
don't know

6. ...having more opportunity to upgrade my professional/technical skills through continuing education.
(1) extremely unlikely
(2) unlikely
(3) u.rdecided
(4) likcly
(5) extremely likely
don't know

7. ...having more reasonable work hours.
(1) extrcmely unlikely
(2) unlikely
(3) undecided
(4) likely
(5) extremely likely
don't know

8. ...having better vacation/leave benefits.
(1) extremely unlikely
(2) unlikely
(3) undecided
(4) likely
(5) extremely likely
don't know

9. ...having superiors who acknowledge the value of my work.
(1) extremely unlikely
(2) unlikely
(3) undecided
(4) likely
(5) extremely likely
don't know 
I believe that remaining in the Navy will result in my....

10. ...having more employment security.
(1) extremely unlikely
(2) unlikely
(3) undecided
(4) likely
(5) cxtremely likely
don't know

11. ...having a positıon that includes better support facilities (staff, equipment, workplace).
(1) extremely unlikely
(2) unlikely
(3) undecided
(4) likely
(5) extremely likely
don't know

12. ...receiving a fair and equitable salary for the work I do.
(1) extremely unlikely
(2) unlikely
(3) undecided
(4) likely
(5) extremely likely
don't know

13. ...having more opportunity to develop formal and informal relationships with other members.
(1) extremely unlikely
(2) unlikely
(3) undecided
(4) likely
(5) extremely likely
don't know

14. ...working with a more flexible/responsive organisation.
(1) extremely unlikely
(2) unlikely
(3) undecided
(4) likely
(5) extremely likely
don't know

15. ...having better fringe benefits such as medical/dental coverage, sick leave, etc.
(1) extremely unlikely
(2) unlikely
(3) undecided
(4) likely
(5) extremely likely
don't know

16. ...having more geographical stability.
(1) extremely unlikely
(2) ur.iikely
(3) undecided
(4) likely
(5) extremely likely
don't know 


\section{1 believe that remaining in the Navy will result in my....}

17. ...having more control over when I take my vacation.
(1) extremely unlikely
(2) unlikely
(3) undecided
(4) likcly
(5) extremely likely
don't know

18. ...being free from temporary assignments/travel on short notice.
(1) extremely unlikely
(2) unlikcly
(3) undecided
(4) likcly
(5) extremely likely
don't know

19. ...having more opportunity to progress in rank.
(1) extremely unlikely
(2) unlikely
(3) undecided
(4) likcly
(5) extremely likely
don't know

20. ...having more opportunity to move to a variety of other professionally/technically related employment positions.
(1) extremely unlikely
(2) unlikely
(3) undecided
(4) likely
(5) ext! smely likely
don't know

21. ...being able to spend more quality time with my family.
(1) extremely unlikely
(2) unlikely
(3) undecided
(4) likely
(5) extremcly likely
don't know 
INSTRUCTIONS - The following questions relate to your own personal feelings and how others feel about you remaining in the Navy. Please indicate your response by circling one of the five alternatives. If you don't know, indicate by putting a check mark in the appropriate space.

1. For me, remaining in the Navy would be...
(a) (1) extremely bad
(2) bad
(3) undecided
(4) good
(5) extremely good
don't know
(b) (1) extremely unrewarding
(2) unrewarding
(3) undecided
(4) rewarding
(5) extremely rewarding don't know

(c) (1) extremely unplcasant

(2) unpleasant

(3) undecided

(4) pleasant

(5) extremely pleasant don't know

(d) (1) extremely disadvantageous

(2) disadvantageous

(3) undecided

(4) advantageous

(5) extremely advantag-jus don't know

2. Most people who are important to me thirix I...
(1) definitely should not
(2) probably should not
(3) undecided
(4) probably should
(5) definitely shruld remain in the Navy
don't know 
3. My spouse (or closest personal friend, if not married) thinks I...
(1) definitely should not
(2) probably should not
(3) undecided
(4) probably should
(5) definitely should remain in the Navy
don't know

INSTRUCTIONS - The following statements deal with the consequences to you of leavin: the Navy. It is understood that you may be serving under obligatory service and must remain in the Navy for a specific period even though you would rather leave at this time. Nevertheless, please complete the questions, by circling onc of the five alternatives, as if you were currently free to pursuc either opti in. If you don't know. indicate by putting a check mark in the appropriate space.

\section{I believe that leaving the Novy will result in my...}

1. ...having more control over the type of work that I do.
(1) extremcly unlikely
(2) unlikely
(3) undecided
(4) likely
(5) extremely likely
don'l know

2. ...having more control over the scheduling of my work.
(1) extremely unlikely
(2) unlikely
(3) undecided
(4) likely
(5) extremely likely
don't know

3. ...having more control over where (geographical location) I work.
(1) extremely unlikely
(2) unlikely
(3) undecided
(4) likely
(5) extremely likely
don't know 
I believe that leaving the Nary will result in my...

4. ...being engaged in work that permits me to maintain my professional/technical skills.
(1) extremely unlikely
(2) unlikely
(3) undecided

(4) likely

(5) extremely likely

don't know

5. ...having better pension benefits.
(1) extremely unlikely
(2) unlikely
(3) undecided
(4) likely
(5) extremely likely
don't know

6. ...having more opportunity to upgrade my professional/technical skills through continuing education.
(1) extremely unlikely
(2) unlikely
(3) undecided
(4) likely
(5) extrenrely likely
don't know

7. ...having more reasonable work hours.
(1) extremely unlikely
(2) unlikely
(3) undecided
(4) likely
(5) extremely likely
don't know

8. ...having better vacation/leave benefits.
(1) extremely unlikely
(2) unlikely
(3) undecided
(4) likely
(5) extremely likely
don't know

S. ...having superiors who acknowledge the value of my work.
(1) extremely unlikely
(2) unlikely
(3) undecided
(4) likely
(5) extremely likely
don't know

10. ...having more employment security.
(1) extremely unlikely
(2) unlikely
(3) undecided
(4) likely
(5) extremely likely
don't know 
I believe that leaving the Navy will result in my...

11. ...having a position that includes better support facilities (staff, equipment, workplace).
(1) extremely unlikely
(2) unlikely
(3) undecided

(4) likely

(5) extremely likely

don't know

12. ...receiving a fair and equitable salary for the work $\mathbf{I}$ do.
(1) extremely unlikely
(2) unlikcly
(3) undecided
(4) likely
(5) extremely likely
don't know

13. ...having more opportunity to develop formal and informal relationships with other mcmbers.
(1) extremely unlikely
(2) unlikely
(3) undecided
(4) likely
(5) extremely likely
don't know

14. ...working with a more flexible/responsive organisation.
(1) extremely unlikely
(2) unlikely
(3) undecided
(4) likely
(5) extremely likely
don't know

15. ...having better fringe benefits such as medical/dental coverage, sick leave, etc.
(1) extremely unlikely
(2) unlikely
(3) undecided
(4) likely
(5) extremely likely
don't know

16. ...having more geographical stability.
(1) extremely unlikely
(2) unlikely
(3) undecided
(4) likely
(5) extremely likely
don't know

17. ...having more control over when I take my vacation.
(1) extremely unlikely
(2) unlikely
(3) undecided
(4) likely
(5) extremely like!y
don't know 
I believe that leaving the Navy will result in my...

18. ...being frec from temporary assignments/travel on short notice.
(1) extremely unlikely
(2) unlikely
(3) undecided
(4) likcly
(5) extremely likely
don't know

19. ...having more opportunity to progress in rank.
(1) extremely unlikely
(2) unlikely
(3) undecided
(4) likcly
(5) extremely likely
don't know

20. ...having more opportunity to move to a variety of other professionally/technically related employment positions.
(1) extremely unlikely
(2) unlikely
(3) undecided
(4) likely
(5) extremely likely
don't know

21. ...being able to spend more quality time with my family.
(1) extremely unlikely
(2) unlikely
(3) undecided
(4) likely
(5) extremely likely
don't know

INSTRUCTIONS - The following questions relate to your own personal feelings and how others feel about you leaving the Navy. Please indicate your response by circling one of the five alternatives. If you don't know, indicate by putting a check mark in the appropriate space.

1. For me, leaving the Navy would be...
(a) (1) extremely bad
(2) bad
(3) undecided
(4) good
(5) extremely good
don't know 
For me, leaving the Navy would be...
(b) (1) extremely unrewarding
(2) unrewarding
(3) undecided
(4) rewarding
(5) extremely rewarding don't know

(c) (1) extremely unpleasant

(2) unpleasant

(3) undecided

(4) pleasant

(5) extremely pleasant

don't know

(d) (1) extremely disadvantageous

(2) disadvantageous

(3) undecided

(4) advantageous

(5) extremely advantageous

don't know

2. Most people who are important to me think I...
(1) definitely should not
(2) probably should not
(3) undecided
(4) probably should
(5) definitely should leave the Navy
don't know

3. My spouse (or closest personal friend, if not married) thinks $1 .$.
(1) definitely should not
(2) probably should not
(3) undecided
(4) probably should
(5) definitely should leave the Navy
don't know 


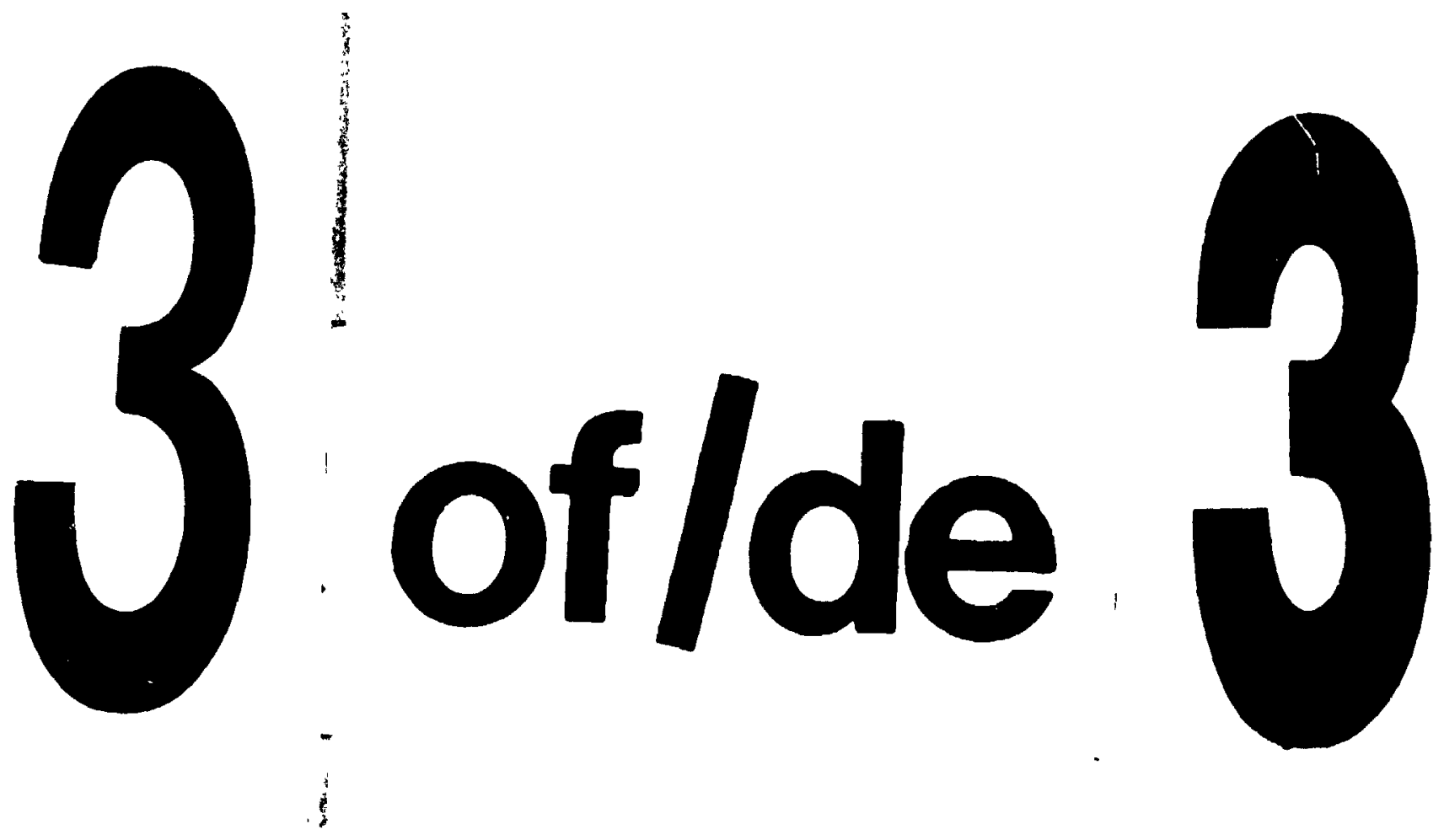

PM-1 3\%" $x 4 "$ PHOTOGRAPHIC MICROCOPY TARGET , NES 1010a ANSI/ISO $\# 2$ EOUIVALENT

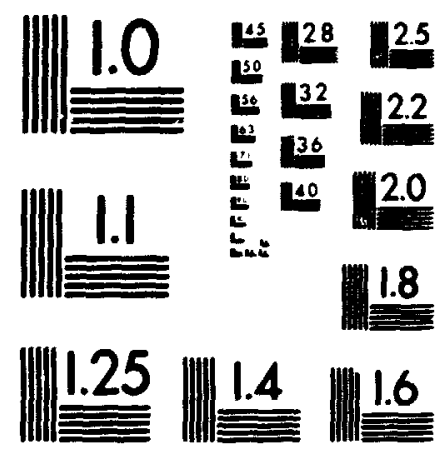


INSTRUCTIONS - The following statements ask you to evaluate, in general, the importance to you of different aspects of employment. Do not provide an evaluation of your current position. Instead, report how much you value these aspects in general. Please indicate your response by circling one of the five alternatives. If you don't know, indicate by putting a check mark in the appropriate space.

\section{In general, I feel that...}

1. having control over the type of work that I do is
(1) extremely unimportant
(2) unimportant
(3) undecided
(4) important
(5) extremely important
don't know

2. having control over the scheduling of my work is
(1) extremely unimportant
(2) unimportant
(3) undecided
(4) important
(5) extremely important
don't know

3. having control over where (geographical location) I work is
(1) extremely unimportant
(2) unimportant
(3) undecided
(4) important
(5) extremely important
don't know

4. being engaged in work that permits me to maintain my professional/technical skills is
(1) extremely unimportant
(2) unimportant
(3) undecided
(4) important
(5) extremely important
don't know

5. having good pension benefits is
(1) extremely unimportant
(2) unimportant
(3) undecided
(4) important
(5) extremely important
don't know 


\section{In general, I feel that...}

6. having an opportunity to upgrade my professional/technical skills through continuing education is
(1) extremely unimportant
(2) unimportant
(3) undecided
(4) important
(5) extremely important
don't know

7. having reasonable work hours is
(1) extremely unimportant
(2) unimportant
(3) undecided
(4) important
(5) extremely important
don't know

8. having good vacation/leave benefits is
(1) extremely unimportant
(2) unimportant
(3) undecided
(4) important
(5) extremely important
don't know

9. having superiors who acknowledge the value of my work is
(1) extremely unimportant
(2) unimportant
(3) undecided
(4) important
(5) extremely important
don't know

10. having employment security is
(1) extremely unimportant
(2) unimportant
(3) undecided
(4) important
(5) extremely important
don't know

11. having a position that includes good support facilities (staff, equipment, workplace) is
(1) extremely unimportant
(2) unimportant
(3) undecided
(4) important
(5) extremely important
don't know

12. receiving a fair and equitable salary for the work I do is
(1) extremely unimportant
(2) unimportant
(3) undecided
(4) important
(5) extremely important
don't know 


\section{In general, I feel that...}

13. having the opportunity to develop formal and informal relationships with other members is
(1) extremely unimportant
(2) unimportant
(3) undecided
(4) important
(5) extremcly important
don't know

14. working with a flexible/responsive organisation is
(1) extremely unimportant
(2) unimportant
(3) undecided
(4) important
(5) extremely important
don't know

15. having good fringe benefits such as medical/dental coverage, sick leave, etc is
(1) extremely unimportant
(2) unimportant
(3) undecided
(4) importani
(5) extremely important
don't know

16. having geographical stability is
(1) extremely unimportant
(2) unimportant
(3) undecided
(4) important
(5) extremely important
don't know

17. having control over when I take my vacation is
(1) extremely unimportant
(2) unimportant
(3) undecided
(4) important
(5) extremely important
don't know

18. being free from temporary assignments/travel on short notice is
(1) extremely unimportant
(2) unimportant
(3) undecided
(4) important
(5) extremely important
don't know 
In peneral, I feel that...

19. having the opportunity to progress in rank is
(1) extremely unimportant
(2) unimportant
(3) undecided
(4) important
(5) extremely important
don't know

20. having the opportunity to move to a variety of other professionally/technically related employment positions is
(1) extremely unimportant
(2) unimportant
(3) undecided
(4) important
(5) extremely important
don't know

21. being able to spend quality time with my family is
(1) extremely unimportant
(2) unimportant
(3) undecided
(4) important
(5) extremely important
don't know

INSTRUCTIONS - The following questions relate to how much influence others have on your decision to remain in the Navy or leave. Please indicate your response by circling one of the five alternatives. If you don't know, indicate by putting a check mark in the appropriate space.

1. With respect to staying in or leaving the Navy, I want to do what those who are important to me think I should do
(1) not at all
(2) slightly
(3) undecided
(4) somewhat
(5) very much
don't know 
2. With respect to staying in or leaving the Navy, I want to do what my spousc (or closest personal friend, if not married) thinks I should do.
(1) not at all
(2) slightly
(3) undecided
(4) somewhat
(5) very much
don't know

INSTRUCTIONS - The following statements reflect your perceptions and future intentions with respect to leaving or remaining in the Navy. If you are under obligatory service, please respond to the statements according to your intention to remain or leave at the end of your obligatory service. If you are not serving under terms of obligatory service, please respond to the statements according to your intention to stay or leave the Navy within two years or less. Please indicate your response by circling one of the five alternatives. If you don't know, indicate by putting a clieck mark in the appropriate space.

1. At the conclusion of my obligatory service; the end of my current contract; or within the next two years or less, I intend to leave the Navy.
(1) extremely unlikely
(2) unlikely
(3) undecided
(4) likely
(5) extremely likely
don't know

2. Within two years, I will be at CRA (Compulsory Retirement Age) but would accept an extension of service if offered.
(1) extremely unlikely
(2) unlikely
(3) undecided
(4) likely
(5) extremely likely
don't know 
3. I have...
(1) definitely no control
(2) probably no control
(3) undecided
(4) probably some control
(5) definitely complete control
don't know

over whether or not I leave the Navy at the end of obligatory service or within two years or less.

4. I feel that I have a moral obligation to remain in the Navy if given the choice.
(1) strongly disagrce
(2) probably disagree
(3) undecided
(4) probably agree
(5) strongly agree
don't know

5. Should I remain in the Navy, there is little opportunity for me to have a personally rewarding career.
(1) strongly disagree
(2) probably disagree
(3) undecided
(4) probably agree
(5) strongly agree
don't know

6. I am remaining in the Navy only because I have uther considerations (too close to pension to leave now, financial obligations, family responsibilities, job security etc.)
(1) strongly disagree
(2) probably disagree
(3) undecided
(4) probably agree
(5) strongly agree
don't know

7. What are the chances that you can find a better alternative to your current employment outside the Navy?
(1) extremely unlikely
(2) unlikely
(3) undecided
(4) likely
(5) extremely likely
don't know 
8. Generally, I am satisfied with my Naval career.
(1) strongly disagrce
(2) probably disagrec
(3) undecided
(4) probably agrec
(5) strongly agree
don't know

\section{PART D}

INSTRUCTIONS - The following asks for biographical information. Please check off or write in the appropriate spaces.

1. What is your rank?

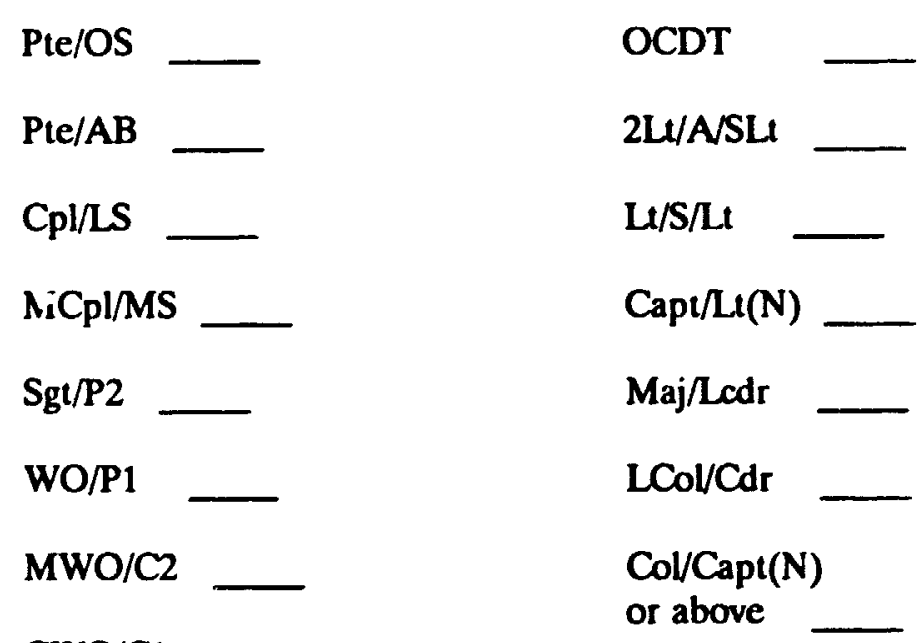

$\mathrm{CWO} / \mathrm{C1}$

2. What is your element? (uniform assigned to wear)

Sea ___ Land___ Air____

3. What is your military occupation? (please give MOC number e.g. Mar Eng Mech 312)

4. Place of employment (write in name of ship or indicate flect school with a check mark) 
5. How many months have you served on board your current ship or have you served at Fleet School?

6. Print the number of completed years you have served in the Navy (Regular Force only).

7. What are your terms of service?

(1) Basic engagement (fixed period of service 3 or 5 years)

(2) Short engagement (fixed period of 9 years)

(3) Short service (short engagement with prior service as Ocdt)

(4) Intermediate engagement (fixed period of service 20 years)

(5) Indefinite period of service

(6) Other (please specify)

8. How many completed years remaining before your present terms of service are completed or when you reach CRA (Compulsory Retirement Age)?

9. Are you currently serving under terms of obligatory service?
(1) NO
(2) YES
If yes, how many more months?

10. Gender

(1) Male

(2) Female

11. Year of birth

12. Marital Status
(1) married
(2) single
(3) divorced
(4) widowed
(5) separated
(6) common law 
13. Number of dependents

14. What is your First Official Language (FOL)?
(1) French
(2) English

15. What was the highest level of education you completed?

(1) Elementary school

(2) Some high school

(3) High school graduate

(4) Some community college or university

(5) Bachelor's degree

(6) Master's degree or higher

16. Please give the last 4 numbers of your SIN number (optional)

INSTRUCTIONS - The following question is designed to sum up your personal evaluation of the importance each of the following is to you at this time. Please put, in order of importance, the following, with 1 being the most important and 4 being the least important. If two are of equal importance to you, indicate by putting the same number beside each. Ask yourself, if given the opportunity to progress in your Naval career at the possible expense of disrupting family life or at the risk of losing other career opportunities outside the Navy, which would you consider more important?

Career in the Navy

Family

Present position

Obtaining a career outside the Navy 


\section{GENERAL COMMENTS}

Please write in any comments you may have concerning the design of this questionnaire and/or its content. 
END
$01 \cdot 06 \cdot 92$

FIN 